\title{
SAĞLIK BAKANLIĞI TARAFINDAN KABUL EDILEN GELENEKSEL VE TAMAMLAYICI TIP UYGULAMALARI VE BUNLARIN HUKUKA UYGUNLUĞUNUN DEĞERLENDİRILMESI
}

\author{
(Araştırma Makalesi)
}

DOI: https://doi.org/10.33717/deuhfd.998230

Dr. Özge ARPACI

\begin{abstract}
$\ddot{\mathbf{O z}}$
Günümüzde gerek dünya genelinde, gerekse ülkemiz özelinde geleneksel ve tamamlayıcı tedavi yöntemlerine duyulan ilgi artmış ve artmaya da devam etmektedir. Hastaların bu şekilde kendi toplum kültürleriyle uyum gösteren farklı çözüm yolları aramasına ise konvansiyonel tıpta, özellikle psikiyatrik ve bazı kronik hastalıkların tam bir tedavisinin bulunmaylşı, mevcut tedavinin yan etkilerinin fazlalığl, konvansiyonel tıp tedavisine ulaşmanin fiziki zorlukları ve teknolojinin gelişmesiyle birlikte tedavi ücretlerinin artması sebep olmuştur. Ancak geleneksel ve tamamlayıcı tedavi yöntemlerinin çoğu, konvansiyonel tıp uygulamalarına nazaran, modern bilimsel ve güvenilir araştırma kriterleri ile araştırılmamış ve kanttlanmamış uygulamalardır. Geleneksel ve tamamlayıcı tedavi yöntemleriyle ilgili en temel sorun, her bir uygulamanın savunucularının genellikle pozitif bilim savunucuların ikna edebilecek şekilde açılamalarını bilimsel verilerle doğrulayamamalarıdır. Ancak bu uygulamaların kanitlanmamış olması bunların yanlış olduğu sonucunu doğurmamalı ve varlığ reddedilmemelidir. Nitekim Sağlık Bakanlığ, yayınlamış olduğu "Geleneksel ve Tamamlayıcı Tip Uygulamaları Yönetmeliği" ile bazı geleneksel ve tamamlayıcı tedavi yöntemlerini düzenleme gereksinimi duymuş ve böylece ilgili tedavi yöntemlerine hukuki bir zemin hazırlamıştır. Ancak ilgili yönetmelik, geleneksel ve tamamlayıcı tedavi yöntemlerinin eğitimsiz ve yetkisiz kişilerin elinde suistimal edilmesini engellemeyi amaçlaması yönünden olumlu bir adım olmakla birlikte, hukuki yönden eksik hükümler içermektedir. Zira ilgili yönetmelikte, ne uygulanacak yöntemlerin hukuka uygun sayllması için gerekli özel şartlara, ne de
\end{abstract}

Ankara Hacı Bayram Veli Üniversitesi Hukuk Fakültesi, Medeni Hukuk Anabilim Dalı Araştırma Görevlisi, Ankara (ozge.arpaci@hbv.edu.tr), ORCID: 0000-0001-7871-7819 (Geliş Tarihi: 19.02.2021-Kabul Tarihi: 25.04.2021) 
uygulayıcıların hukuki sorumluluklarına iliş̧kin özel hükümlere yer verilmiştir. Oysa ki, geleneksel ve tamamlayıcı tıp uygulamaları, konvansiyonel tıp uygulamalarından farkl karakteristik özelliklere ve kapsama sahiptir. Dolaylstyla, daha çok konvansiyonel tıp uygulamalarına iliş̧in gelişstirilen genel ilkelerin geleneksel ve tamamlayıcı tedavi yöntemlerine uygulanması halinde, bunların kapsamı ve yoğunluğu değisşiklik gösterebilmektedir. Ülkemizde geleneksel ve tamamlayıcı tıp uygulamalarına ilişkin olarak literatür ve mahkeme kararları seyrektir ve özel hukuk kurallarl bulunmamaktadır. Bu yüzden, geleneksel ve tamamlayıcı tıp uygulamalarının temelleri, kapsamı ve sınırları açısından konvansiyonel tıbbi tedavinin genel ilkelerinden yararlanma zorunluluğu hastl olmakla birlikte, geleneksel ve tamamlayıcı tedavi yöntemlerinin, konvansiyonel standart uygulamalara nazaran, farkl özelliklere sahip olmast sebebiyle, hukuka uygunluğu için gerekli özel şartların saptanması ve ilgili yöntemlerin perspektifine uygun hukuki standartların geliştirilmesi ihtiyacı bulunmaktadır.

\title{
Anahtar Kelimeler
}

Geleneksel ve Tamamlayıcı Tip, Aydınlatma Yükümlülügü, Tıbbi Standart, Endikasyon, Komplikasyon Yönetimi

\section{TRADITIONAL AND INTEGRATIVE MEDICINE PRACTICES APPROVED BY THE MINISTRY OF HEALTH AND EVALUATION OF THE COMPLIANCE OF THESE PRACTICES WITH THE LAW}

\author{
(Research Article)
}

\begin{abstract}
Today, the interest in the traditional and integrative treatment methods have increased and has been increasing both in our country and around the world. In traditional medicine, the inability to treat psychiatric and some chronic diseases in full as well as increased side effects of an existing treatment, physical barriers before access to the conventional medical treatment and increased costs of treatment with the development of the technology have caused patients search for different solutions consistent with the culture of the communities they live in. Majority of the traditional and integrative treatment methods are practices that are not studied and proven through contemporary scientific and reliable research criteria when compared to the conventional medical practices. The main problem about the traditional and integrative treatment methods is the failure of the advocates of each practice in proving their claims with scientific data in a manner convincing the advocates of the
\end{abstract}


positive science. However, unproven nature of these practices should not lead to the conclusion that they are wrong and their existence should not be denied. Therefore, the Ministry of Health enacted the "Regulation on Traditional and Integrative Medicine Practices" in parallel with the requirement to regulate some traditional and integrative medicine practices and laid down the legal foundations of the relevant treatment methods. However, the regulation is a positive step towards preventing misconduct of the uneducated and unauthorized persons in connection with the traditional and integrative medicine methods although its provisions are not sufficient in legal terms. This is because the relevant regulation does not provide for any special criterion aimed at considering the methods as legally compliant methods or special provisions on legal liabilities of the practitioners. Traditional and integrative medicine practices have characteristics and scope different than the conventional medicine practices. Therefore, general principles for conventional medicine practices should not apply to the traditional and integrative medicine practices at any time and in any case. In our country, the number of literature and court decisions is limited about traditional and integrative medicine practices. For this reason, it is mandatory to use the general principles of the conventional medical treatment in connection with the fundamentals, scope and limitations of the traditional and integrative medicine practices, and it is required to set special conditions on legal compliance and develop legal standards in parallel with the perspective of the relevant methods as traditional and integrative treatment methods have different characteristics than the conventional standard practices.

\section{Keywords}

Traditional and Integrative Medicine, Obligation to Inform, Medical Standard, Indications, Complication Management 


\section{GİRIŞ}

Konvansiyonel (modern) tıp bilimi, dünyada hakim bir biçimde sağlık sistemleri tarafindan kullanılmaktadır. Zira konvansiyonel tip; tedavinin hastalara uygulanmasından önce bilimsel verilerle ilgili tedaviyi ölçüp değerlendirmekte, somut kanıtlara dayanmakta ve dolayısıyla uygulanmasında güven oluşturmaktadır. Konvansiyonel tıp bilimi, pozitif bilimlerin büyük başarılarıyla şekillenmesine rağmen, günümüzde azımsanamayacak sayıda insan, ya konvansiyonel tıp biliminin uygulamalarına gerek maddi, gerekse fiziki koşullar nedeniyle erişememekte ya da kendi iradesi doğrultusunda bu uygulamaları tercih etmemektedir. Özellikle Avrupa'da ve Amerika'da geleneksel ve tamamlayıcı tıp uygulamalarının popülaritesinin artması neticesinde, günümüzde pek çok kişi geleneksel ve tamamlayıcı tıp uygulamalarına ilgi duymakta ve konvansiyonel tıp uygulamalarından ziyade bunları tercih etmektedir ${ }^{1}$.

Geçmiş yıllarda daha çok "alternatif tıp" olarak karşımıza çıkan bu uygulamalar, konvansiyonel tıp da dediğimiz günümüz hakim tıp anlayışının dışında kalan, ancak onu destekleyen veya tamamlayan uygulamalardır. $\mathrm{Bu}$ uygulamalar, sağlıklı bireylerin fiziksel veya zihinsel hastalıklardan korunarak sağlıklarının sürdürülmesinde, hasta bireylerin ise hastalıklarını tedavi etmede kullanılan, farklı kültürel özellikler taşıyan, inanç ve tecrübelere dayalı bilgi, beceri ve uygulamaların bütünüdür².

Tip dünyasinda son zamanlarda taraf toplayan ve toplamaya da devam eden görüsse göre ${ }^{3}$, geleneksel ve tamamlayıcı tıp uygulamaları ve konvansiyonel tıp uygulamaları birbirlerine zıt kavramlar olarak görünseler dahi,

1 Öztürk, Yunus Emre/Dömbekci, Hilal Akman/Ünal, Seda Nur: "Geleneksel, Tamamlayıcı ve Alternatif Tıp Kullanımı", Bütünleyici ve Anadolu Tıbbi Dergisi, C. 1, S. 3, Y. 2020, s. 23; Yeşilada, Erdem: "Hekim, Alternatif Tedavi ve Modern Tıp", TTB Sürekli Tıp Eğitimi Dergisi, C. 11, S. 6, Y. 2002, s. 223; Somer, Pervin/Lutz, Emine Elif Vatanoğlu: "Geleneksel ve Tamamlayıcı Tıp Uygulamaları Yönetmeliği'nin Hukuki ve Etik Açıdan Değerlendirilmesi”, Anadolu Kliniği Tıp Bilimleri Dergisi, C. 22, S. 1, Y. Ocak 2017, s. 59.

2 T.C. Sağlık Bakanlığı, "GETAT (Geleneksel ve Tamamlayıcı Tıp Uygulamaları)", https://ezheah.saglik.gov.tr/TR,396642/getat-geleneksel-ve-tamamlayici-tipuygulamalari.html, (E. T. 23.12.2020); Eichelberger, Jan: Medizinrecht, Becksche Kurz Kommentare Band 64 (Hrsg.: Andreas Spickhoff), 3. Auflage, Verlag C. H. Beck, München 2018, Rn. 53.

3 Yeşilada, s. 224; Tokaç, Mahmut: "Geleneksel Tıbba Etik ve Hukuk Yönü ile Bakış", Journal of Biotechnology and Strategic Health Research, C. 3, S. Özel Sayı, Y. 2019, s. 155 vd.; Taştan, Kenan: "Ülkemizde Geleneksel ve Tamamlayıcı Tıbbın Kilometre Taşları", Ankara Medical Journal, C. 18, S. 3, Y. 2018, s. 458 vd. 
hastalığın tedavisinde birbirlerinden ayrılmaz parçalardır. Buna rağmen bazı konvansiyonel tıp doktorları, bu kapsamda yer alan uygulamalara tamamen sırtını dönmekte ve sadece bilimsel verilere dayalı konvansiyonel tıp uygulamalarına yönelmektedir. Dolayısıyla bu reddediş sebebiyle de birçok hasta, mevcut hastalığının tedavisinde konvansiyonel tıp tedavisinin yanı sıra geleneksel ve tamamlayıcı tedavi yöntemlerini kullandıklarını doktorlarından saklamaktadır. Oysa bu uygulamaların varlığının kabul edilmesi, devletin yetkili makamları tarafindan denetlenmesi, eğitimli kişiler tarafından gerçekleştirilmesi gereklidir. Zira bu uygulamaların varlığının yok sayılması, eğitimsiz kişiler tarafından suistimal edilmesine ve umut tacirleri tarafından özellikle çaresizce bir umudun peşinden koşan ağır hastaların istismar edilmesine sebebiyet verebilir ${ }^{4}$. Nitekim T.C. Sağlık Bakanlığı da bu ihtimalleri göz önüne alarak, bu hususu düzenleme ihtiyacı hissetmiştir. Ülkemizde konuya ilişkin gerçekleştirilen gelişmeler ${ }^{5}$ gösteriyor ki, geleneksel ve tamamlayıcı tıp artık hayatımızın bir parçası haline gelmeye başlamıştır.

Bu çalışmada, öncelikle kavram kargaşası yaratabilecek bazı kavramlara açıklık getirilmeye çalışılacaktır. Sonrasında geleneksel ve tamamlayıcı tıp uygulamalarının kapsamına, Türkiye'de bunlara ilişkin yasal düzenlemelere ve bu bağlamda Sağlık Bakanlığı'nca kabul edilen türlerine yer verilecektir. Daha sonra ise, Sağlık Bakanlığı tarafından kabul edilen geleneksel ve tamamlayıcı tıp uygulamalarının tıbbi müdahale olarak sayılıp sayılmadığı değerlendirilecek ve bu doğrultuda hukuka aykırılığın doğmasını engelleyen genel şartlara değinilecektir. Zira ilgili çalışma, doktorun hukuki

4 Örneğin, İsviçre'de tamamlayıcı tıbbın sağlık hizmetlerinde pazar payının yüksek olması sebebiyle İsviçre Anayasası'na 2009 yılında yeni bir hüküm eklenmiştir. Buna göre (Art. 118a BV), Federal Hükümet ve Kantonlar, tamamlayıcı tıbbı sorumluluklarının bir parçası olarak dikkate alınmasını sağlar. Konuya ilişkin ayrıntılı bilgi için bkz. Kieser, Ueli/Nedi, Marian: “Komplementärmedizin: Was legt Art. 118a BV fest?", Hill: Zeitschrift für Recht und Gesundheit, S. 72, Y. 2013, Rn. 2 vd.

5 Bu kapsamda Sağlık Bakanlığı tarafından hangi mesleklerin bu uygulamaları yapabileceği, uygulamaları gerçekleştirecek kişilerin sahip olmaları gereken asgari eğitim standartları ve uygulamaların endikasyon alanları hususunda düzenleme yapılarak, ülkemizde geleneksel ve tamamlayıcı tıp uygulamaları yeni bir boyuta taşınmıştır. Ayrıca Sağlık Bakanlığı Sağlık Hizmetleri Genel Müdürlüğü nezdinde 2012 yılında "Geleneksel, Tamamlayıcı ve Fonksiyonel Tip Uygulamaları Daire Başkanlığı" kurulmuş ve tüm Türkiye genelinde uygulama ve eğitim merkezleri oluşturulmuştur. Aynı şekilde 2014 yılında, Türkiye Sağlık Enstitüleri Başkanlı̆̆ı'na bağlı olarak, "Türkiye Geleneksel ve Tamamlayıcı Tip Enstitüsü” kurulmuştur. İlgili enstitü, kanıta dayalı olarak geleneksel ve tamamlayıcı tıbbın modern tıp ile entegre bir şekilde insan sağlığının korunmasına, iyileştirilmesine, rehabilite edilmesine ve bozulan insan sağlığının düzeltilmesine katk1 sağlamak amaciyla kurulmuştur. 
sorumluluğuna ilişkin olup, doktorun cezai sorumluluğu çalışma kapsamında değildir. Ardından geleneksel ve tamamlayıcı tıp uygulamalarının konvansiyonel tıbbi müdahalelere nazaran, ayrık durumları ve karakteristik özellikleri dikkate alınarak, bu uygulamaların hukuka uygun sayılabilmesi için gerekli genel şartların özel içeriği tespit edilmeye çalışlacaktır.

\section{GELENEKSEL VE TAMAMLAYICI TIP UYGULAMALARI}

\section{A. Genel Olarak}

Geleneksel ve tamamlayıcı tıp uygulamaları, yüzyıllar öncesine dayanmaktadır. Bilindiği gibi, şifacılar kendi etki alanlarıyla sınırlı olarak geleneksel bazı yöntemlerle (bitkisel ilaç tedavisi, sülük tedavisi gibi) yüzyıllar boyunca insanları iyileştirmeye çalışmışlardır. Ancak zamanla batıda laikleşme sürecinin başlamasıyla birlikte, deneysel ve rasyonel tıbbi uygulamaların önemi artmaya başlamıştır. Bununla birlikte, toplumda yine bazı insanlar için hastalıkların tedavisinde üfürükçülerin, şifacıların ve din adamlarının etkinliği devam etmiştir. 19. yy. ortalarında ise geleneksel yöntemler, yerinde saydığı ve gelişemediği için etkisini kaybetmiştir. Geleneksel yöntemler yerine yeni ve etkili çağdaş tedavi yöntemlerinin ortaya çıkması ve tıbbi cihaz teknolojisinin başlaması ile birlikte deneysel tıbba eğilim artmıştır. Ancak geleneksel ve tamamlayıcı tıp uygulamaları, hiçbir zaman tam anlamıyla terk edilmemiş, aksine varlığını insanlığın her döneminde sürdürmüştür ${ }^{6}$.

Geleneksel ve tamamlayıcı tıp uygulamaları günümüzde ise, neredeyse her coğrafyada, yeniden yaygınlaşmaya başlamıştır. Örneğin, bazı Asya (Çin, Kore, Hindistan gibi) ve Afrika (Etiyopya, Uganda, Tanzanya, Ruanda gibi) ülkelerinde toplumun yüzde sekseni geleneksel ve tamamlayıcı tıp uygulamalarından temel sağlık hizmeti olarak faydalanmaktadır. Aynı şekilde (Avrupa ülkeleri, Amerika Birleşik Devletleri, Kanada, Japonya gibi) gelişmiş ülkelerde de toplumun yüzde kırkından fazlasının geleneksel ve tamamlayıcı tıp uygulamalarına başvurduğu bilinmektedir ${ }^{7}$.

6 Konuya ilişkin ayrıntılı bilgi için bkz. Sandoz, Thomas: Alternatif Tıp Tarihi, Çev. Çağrı Eroğlu, Dost Kitabevi, Ankara 2010, s. 13 vd.

7 Konuya ilişkin ayrıntılı bilgi için bkz. Biçer, İsmail/Balçık, Pınar Yalçın: "Geleneksel ve Tamamlayıcı Tıp: Türkiye ve Seçilen Ülkelerinin İncelenmesi”, Hacettepe Sağlık İdaresi Dergisi, C. 22, S. 1, Y. 2019, s. 247 vd.; Aydın, Sabahattin: "DSÖ ve Gelenekten Küresele Tıbbın Alternatif Serüveni”, Sağlık Düşüncesi ve Tıp Kültürü Dergisi, S. 22, Y. Mart-Nisan-Mayıs 2011-2012, s. 8; Tütüncü, Serpil: "Geleneksel, Alternatif ve Tamamlayıcı Tıp Uygulamalarına Genel Bir Bakış”, Tıbbın Alternatifi Olmaz! 


\section{B. Alternatif-Tamamlayıcı-Geleneksel-Konvansiyonel Tip Kavramı ve Ayrımı}

Tıp kavramı, "hastallkları iyileştirmek, hafifletmek veya önlemek amacryla başvurulan teknik ve bilimsel çalışmaların tümü" olarak tanımlanmıştır ${ }^{8}$. Tıp disiplinin kökeni, insanların diğer insanlara yardım etme ve merak iç güdüsüne, böylece ilk insanların birbirlerine çevrelerindeki doğal ürünlerden faydalanarak yardım etmeye başlamalarına dayanmaktadır. $\mathrm{Bu}$ içgüdülerin tetiklemesiyle insan, zamanla nesilden nesile aktarılan tecrübe ve gözlemlerle tıbbi uygulamaların gelişmesini sağlamıştır. Tıp bilimi, durağan değil, aksine sürekli değişim içerisinde olan bir bilim dalıdır. Zira hastalıklar, zamandan zamana, coğrafyadan coğrafyaya, kültürden kültüre, nesilden nesile farklılıklar taşımakta ve sürekli değişmektedir. Dolayısıyla tıp kavramı, sadece teknik ve bilimsel çalışmalara dayanan konvansiyonel tıp kavramını değil, başka kavramları ve türleri de içerisinde barındırmaktadır. $\mathrm{Bu}$ bağlamda kavram kargaşası yaratabileceği düşüncesiyle, bazı kavramların netleştirilmesi gerekmektedir.

Konvansiyonel tıp, günümüzde "Modern tıp", "Ortodoks tıbbl" ve "Batı tıbbı" ifadeleri ile eş anlamlı olarak kullanılmaktadır'. Konvansiyonel tıp, 19. yüzyılın başından itibaren uygulanmaya başlayan, kanıta dayalı bilimsel yöntemlerden oluşan, klinik deneyimin bilimsel araştırma sonuçları ile desteklendiği ve günümüzde hakim tıp anlayışını ifade eden tıbbi uygulamalardir ${ }^{10}$.

Geleneksel, Alternatif ve Tamamlayıcı Tıp Uygulamaları, Türk Tabipleri Birliği Yayınları, Ankara 2017, s. 11 vd.; Kieser/Nedi, Rn. 2 vd.; Yeşilada, s. 223 vd.

8 Türk Dil Kurumu, https://sozluk.gov.tr, (E.T.: 03.12.2020).

9 Konvansiyonel tıbbın temeli, Hipokrat'ın ortaya attığı bir fikre dayanmaktadır. Buna göre tıp; tanı, tedavi ve prognoz sürecinin ayrıntılı olarak gözlemlenmesi, neden-sonuç ilişkisi kurulması ve edinilen tecrübeler ışığında değerlendirilmesi gereken bir alandır. Bütüncül tıp olarak da adlandırılan integratif tıp ise, modern tıp ile etkinliği ve güvenirliği kanıtlanmış geleneksel, tamamlayıcı ve alternatif tıp uygulamalarının hastanın ruhsal, zihinsel ve duygusal durumu dikkate alınarak, bir bütün halinde ele alınmasına denir, Öztürk/Dömbekci/Ünal, s. 24 vd.; Şahin, Çağnı Emin: "Tıbbın Alternatifi mi? Tıpta Alternatif mi?", Hayat Sağlık: Sağlık ve Sosyal Bilimler Dergisi, S. 17, Y. Temmuz 2018, s. 19; Civaner, M. Murat: "Hekimin Modern Tıp Dışı Yöntemlere Yaklaşımı Nasıl Olmalı?", Toplum ve Hekim, C. 32, S. 1, Y. Ocak-Şubat 2017, s. 11.

10 Şahin, Saliha: “Geleneksel, Tamamlayıcı, Alternatif Tıp Uygulamalarına Genel Bir Bakış”, Türkiye Aile Hekimliği Dergisi, C. 21, S. 4, Y. 2017, s. 159. 
Doktrinde yer alan hakim görüşse ${ }^{11}$ göre alternatif tıp ise, kanıta dayalı bilimsel tıbbi yöntemlerin dışında kalan, konvansiyonel tıbbın yerine ikame edilen her türlü sağlık hizmetidir. Kavramın içerisinde yer alan "alternatif" ifadesi; "seçenek" veya "bir şeyin yerine" anlamlarında kullanılmaktadır. Dolayısıyla alternatif tıp, konvansiyonel tıbbı tamamlayıcı ve destekleyici nitelikte değil; onun dişında ve karşısında olan, ona ikame teşkil eden uygulamalar bütünüdür. Ancak günümüzde genellikle geleneksel veya tamamlayıcı tıp uygulamalarını da içerisine alan genel bir kavram olarak karşımıza çıkmaktadır. Dolayısıyla bu kavramlar arasında, uygulamada belirsizlik olduğu açıktır. Ancak günümüzde birçok uluslararası sağlık kuruluşları tarafından "alternatif tıp" ifadesinin kullanımından kaçınılmakta olduğu da dikkatten kaçmamaktadır. Çünkü bu ifadenin kullanılması ile toplumda, sanki alternatif tıp uygulamalarının konvansiyonel tıbba alternatif oluşturma çabası içerisinde olduğu ve konvansiyonel tıbb1 reddederek, onun yerine uygulanması gerektiği yönünde bir alg1 oluşmaktadır. Dolayısıyla Dünya Sağlık Örgütü (DSÖ) de bu ifadeyi kullanmaktansa, "geleneksel ve tamamlayıcı tup uygulamaları" ifadesini kullanmayı tercih etmektedir ${ }^{12}$. Aynı şekilde, ülkemizde de bu ifadenin kullanımından kaçınıldığı görülmektedir. Şöyle ki; Sağlık Bakanlığı, "Geleneksel, Tamamlayıcı ve Alternatif Tip Uygulamaları Taslak Yönetmeliği”ni 2014 yılının başlarında hazırlamıştır. Ancak Sağlık Bakanlığı'nın talebi üzerine ilgili kurumların eleştiri ve görüşleri doğrultusunda taslakta, taslağın başlığı da dahil olmak üzere, bazı değişiklikler yapılmış ve ilgili yönetmelik "Geleneksel ve Tamamlayıcı Tip Uygulamalart Yönetmeliği,"13 başlı̆̆ ${ }_{1}$ altında 27 Ekim 2014 tarihinde Resmi Gazete'de yayımlanarak yürürlüğe girmiştir ${ }^{14}$. Yine Mayıs 2016 yılında Türk Tabipler Birliği tarafından düzenlenen "Tıbbın Alternatifi Olmaz" başlıklı

11 Oğuz, Yasemin: “Toplum, Bilim ve Tıp Etiği Açısından Alternatif Tıp ve Halk Tıbbı”, Bilim ve Ütopya, S. 25, Y. Temmuz 1996, s. 36 vd.; Mollahaliloğlu, Salih/Uğurlu, F. Gülçin/Kalaycı, Mehmet Zafer/Öztaş, Dilek: "Geleneksel ve Tamamlayıcı Tıp Uygulamalarında Yeni Dönem”, Ankara Medical Journal, C. 15, S. 2, Y. 2015, s. 102.

12 Tokaç, Mahmut: "Geleneksel ve Tamamlayıcı Tıp Uygulamaları Mevzuatı Hakkında", Hayat Sağlık: Sağlık ve Sosyal Bilimler Dergisi, S. 17, Y. Temmuz 2018, s. 22; Mollahaliloğlu/Uğurlu/Kalaycı/Öztaş, s. 102.

$13 \quad 27.10 .2014$ tarihli 29158 sayılı Resmi Gazete'de yayınlanmıştır.

14 Bahsi geçen değişiklikler için bkz. Karahancı, Onur Naci/Öztoprak, Ümit Yaşar/ Ersoy, Mesut/Ünsal, Çağrı Zeybek/Hayırlıdağ, Mustafa/Büken, Nüket Örnek: “Geleneksel ve Tamamlayıcı Tıp Uygulamaları Yönetmeliği ile Yönetmelik Taslağı'nın Karşılaştırılması", Türkiye Biyoetik Dergisi, C. 2, S. 2, Y. 2015, s. 117 vd. 
sempozyumda ${ }^{15}$, konu derinlemesine tartışılmış ve bu ifadenin yanıltıcı olduğu sonucuna ulaşılmıştır. $\mathrm{Bu}$ doğrultuda çalışmamızda bu ifade yerine, "geleneksel ve tamamlayıcı tıp uygulamaları" ifadesini kullanmayı daha yerinde görmekteyiz.

Tamamlayıcı tıp ise, hastaya uygulanan konvansiyonel tıbbi yöntemlere ek olarak, bilimsel olarak kanıtlanmış bir tedavi yöntemi olmadığı halde, hastanın isteğine bağlı olarak, konvansiyonel tıp tedavisinin desteklenmesi amacıyla gerçekleştirilen uygulamalardır. Tamamlayıcı tıp uygulamaları, konvansiyonel tıp uygulamalarına paralel olarak yürütülen, mevcut hastalığın yan etkilerini azaltıcı, hastanın psikolojik durumunu düzeltici, rahatlatıcı, bağışıklığını güçlendirici ve destekleyici tedavileri içermektedir. Bir diğer ifadeyle, tamamlayıcı tıp uygulamaları, konvansiyonel bilimsel uygulamaları tamamlayıcı nitelikte tedavi yöntemleridir. $\mathrm{Bu}$ uygulamaların geleneksel tıp uygulamalarından farkı, uygulandığı ülkede, o ülkenin kendi geleneklerinin bir parçası olarak kabul edilmek zorunda olmaması noktasındadır. Bir diğer deyişle, tamamlayıcı tıp uygulamaları (örneğin, ozon tedavisi gibi) geleneksel olmak zorunda değildir. Eğer tıp uygulaması, uygulandığı ülkenin kendi geleneklerinden doğmamışsa ve hakim sağlik sistemi tarafından da yerleşik bir biçimde uygulanmıyorsa, o uygulama tamamlayıc1 tıp uygulaması olarak tanımlanabilir ${ }^{16}$. Bu uygulamaların alternatif tıp uygulamalarından farkı ise şöyledir: Tamamlayıcı tıp, konvansiyonel tıbbi yöntemleri tamamlayıcı ve destekleyici nitelikteyken; alternatif tıp, konvansiyonel tıbbı reddeden ve onun yerine ikame edilen uygulamalar olarak görülmektedir ${ }^{17}$.

Halk tıbbı olarak da adlandırılan geleneksel tıp ise; köklerini geçmişten alan, nesilden nesile aktarılan değerler, tecrübeler, inançlar ve denemeyanılma yöntemi ile oluşan bilgiler 1şı̆̆ında, fiziksel ve zihinsel hastalıklardan korunmada, tanı koymada ve hastalıkların tedavisinde kullanılan geçmişten günümüze kadar gelen uygulamalar bütünüdür. Geleneksel tıp, alternatif tıbbın ortaya çıktığı coğrafyanın ve yaygın olarak kullanıldıkları dönemin özelliklerini yansıtan uygulamalardır. Ortaya çıktığı ve benimsen-

15 Krş. TTB Halk Sağlığı Kolu, "Tıbbın Alternatifi Olmaz” Sempozyumu, İstanbul, 2016, https://toraks.org.tr/site/sf/nmf/pre_migration/e47a126a58861d852d8c490248f2eacbflc b0b9411deeaac2ad7ebd6b4942cc8.pdf, (E. T.: 24.12.2020).

16 Konuya ilişkin ayrıntılı bilgi için bkz. Tokaç, Tıp Uygulamaları Mevzuatı, s. 22 vd.; Şahin, Tipta Alternatif, s. 17 vd.

17 Hakeri, Hakan: "Geleneksel Tıp Bakımından Ülkemizdeki Hukuki Durum”, Legal Tıp Hukuku Dergisi, C. 4, S. 7, Y. Nisan 2015, s. 18; Öztürk/Dömbekci/Ünal, s. 24; Civaner, s. 10. 
diği coğrafyada ve kültürde geleneksel tıp olarak kabul edilen uygulamalar, bir başka coğrafyada alternatif tıp olarak adlandırılabilirr ${ }^{18}$. Örneğin, bizim coğrafyamızda ortaya çıkan bazı geleneksel tıp uygulamaları (Şamanizm'in uzantısı olan uygulamalar gibi), başka bir coğrafyada ve kültürde alternatif tıp olarak tanımlanabilir ${ }^{19}$.

\section{Türkiye'de Konuya İlişkin Bazı Yasal Düzenlemeler}

DSÖ'nün geleneksel ve tamamlayıcı tıp alanında yapmış olduğu çalışmalar ve aldığı kararlar sonucunda çoğu ülke, buna ilişkin kendi iç hukuklarında bazı yasal düzenlemeler yapma gereği duymuşlardır. Zira DSÖ, geleneksel ve tamamlayıcı tıp uygulamalarının ulusal sağlık politikalarında yer alması gerektiğini kabul etmektedir. DSÖ, bu uygulamaların güvenirliğinin yasal mekanizmalarla sağlanarak, eğitimsiz ve yetkisiz kişilerin elinde suiistimal edilmemesi gerektiğini ve doğru yönde kullanılması halinde onları desteklediğini dile getirmektedir ${ }^{20}$. Bu bağlamda, geleneksel ve tamamlayıcı tıp uygulamalarının kanıta dayalı, güvenilir ve etkin bir biçimde sağlık sistemine entegrasyonu amacıyla, Türkiye'de de konuya ilişkin bazı yasal düzenlemelere yer verilmiştir. Böylece Sağlık Bakanlığı, 2013-2017 Stratejik Plan1 ${ }^{21}$ ve Türkiye Cumhuriyeti Onuncu Kalkınma Planı ${ }^{22}$ çerçevesinde, bu düzenlemelerle geleneksel ve tamamlayıcı tıp yöntemlerinin eğitimli kişiler ve istenilen donanım ve teçhizata sahip sağlık kuruluşları tarafından verilmesini ve bunların denetlenmesini zorunlu hale getirmiştir.

Türkiye'de geleneksel ve tamamlayıcı tıp uygulamalarına ilişkin olarak ilk düzenleme, "Akupunktur Tedavi Yönetmeliğì"

18 Sarıyev, Ayşe Erol: Alternatif Tıbbi Yöntemlerden Kaynaklanan Hukuki Sorumluluk, Adalet Yayınevi, Ankara 2015, s. 5; Mollahaliloğlu/Uğurlu/Kalaycı/Öztaş, s. 102; Aydın, s. 8.

19 DSÖ’ye göre ise geleneksel tıp, “fiziksel ve ruhsal hastallkların önlenmesinde, bunlara tanı koymada, tedavi edilmesinde ve bunların yanında sağlığın korunmasında ve iyileştirilmesinde farklı kültürlere özgü teoriler, inançlar ve deneyimlere dayanan bilgi, beceri ve uygulamaların tümü"dür, General Guidelines for Methodologies on Research and Evaluation of Traditional Medicine, 2000, https://apps.who.int/iris/bitstream/handle/ 10665/66783/WHO_EDM_TRM_2000.1.pdf, (E.T.: 03.12.2020).

20 Tokaç, Tıp Uygulamaları Mevzuatı, s. 22; Biçer/Balçık, s. 245; Aydın, s. 9 vd.

21 T.C. Sağlık Bakanlığı 2013-2017 Stratejik Planı metni için bkz. https://pydbfiles.saglik. gov.tr/documents/stratejik\%20plan\%202013-2017.pdf, s. 16 vd. (E.T.: 28.03.2021).

22 T.C. Kalkınma Bakanlığı Onuncu Kalkınma Planı metni için bkz. https://www.sbb. gov.tr/wp-content/uploads/2018/11/Onuncu-Kalkınma-Plan1-2014-2018.pdf, s. 35 (E.T.: 28.03.2021)

$23 \quad 29.05 .1991$ tarihli 20885 sayılı Resmi Gazete'de yayınlanmıştır. 
yayımlanmıştır ${ }^{24}$. Daha sonra ise 2002 y1lında "Akupunktur Tedavisi Uygulanan Özel Sağlık Kuruluşları ile Bu Tedavinin Uygulanması Hakkında Yönetmelik"25 başlığı altında farklı bir düzenlemeye yer verilmiştir ${ }^{26}$. Sonrasında Sağlık Bakanlığı, 2010 yılında insan sağlığını koruyucu ve tedavi edici etkileri olan bitkisel ürünlerin nasıl ruhsatlandırılacağına ilişkin “Geleneksel Bitkisel Tıbbi Ürünler Yönetmeliği”"ni ${ }^{27}$ yayınlamıştır. Daha sonra ise, 663 sayılı "Sağllk Bakanlı̆̆ı ve Bă̆lı Kuruluşlarının Teşkilat ve Görevleri Hakkında Kanun Hükmünde Kararname"28 2011 yılında yayımlanmış ve konuya ilişkin ileride hazırlanacak düzenlemelerin yasal dayanağ

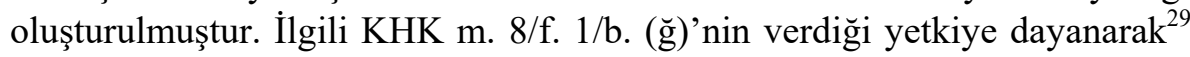
Sağlık Bakanlığ Sağlık Hizmetleri Genel Müdürlüğü, 2014 yılında “Geleneksel ve Tamamlayıcı Tıp Uygulamaları Yönetmeliği”ni yayınlayarak, akupunktur dışında yer alan diğer uygulamaları ilk defa düzenlemiştir. İlgili yönetmelikte, geleneksel ve tamamlayıcı tıp kavramları ve aralarındaki farklar açıklanmamakla birlikte; bu uygulamaların türleri ve türlerin tanımları, amaçları, kapsamları, onları gerçekleştirecek olan kişiler, uygulama merkezlerinin donanımları, standartları ve denetimlerine ilişkin genel bir düzenleme getirilerek, geleneksel ve tamamlayıcı tıp uygulamalarına hukuki bir zemin hazırlanmıştır ${ }^{30}$. Bu yönetmeliğin yayınlanması sonucunda,

24 Bu yönetmeliğin amacı, ülkemizde akupunktur tedavisinin bilimsel yöntemlerle yapılmasının sağlanmasıdır. İlgili yönetmelikte, akupunktur yöntemlerinin tanımlanmasına, kamu kurum ve kuruluşları ile gerçek kişilerin ve özel hukuk tüzel kişilerinin gerçekleştirdikleri akupunktur faaliyetlerinde standardizasyonun sağlanmasına ve bu kapsamda üst komisyon kurulmasına ilişkin hükümler yer almaktadır.

$25 \quad$ 17.09.2002 tarihli 24879 sayılı Resmi Gazete' de yayınlanmıştır.

26 Bu düzenlemenin amacı ise, toplumun sağlığını korumak maksadıyla akupunktur tedavisinin bilimsel yöntemlerle yapılması ve bu tedavinin uygulandığı özel sağlık kuruluşlarının açılmasına, çalışmasına ve denetlenmesine ilişkin usul ve esasları belirlemektir. Türkiye'de bu yönetmelik ile birlikte, Sağlık Bakanlığı'ndan alınan izinle üniversiteler akupunktur eğitimi vermeye başlamıştır. Ayrıca yurt dışında veya yurt içinde eğitim almış kişiler, sınava tabi tutularak başarılı olanlara akupunktur uygulama yetkisi verilmiştir.

$27 \quad 06.10 .2010$ tarihli 27721 sayılı Resmi Gazete'de yayınlanmıştır.

$28 \quad 02.11 .2011$ tarihli 28103 sayılı Resmi Gazete'de yayınlanmıştır.

29 İlgili maddeye göre, Sağlık Hizmetleri Genel Müdürlüğü’nün görevleri arasında, Geleneksel, tamamlayıcı ve alternatif tıp uygulamaları ile ilgili düzenleme yapmak ve sağl1k beyanı ile yapılacak her türlü uygulamalara izin vermek ve denetlemek, düzenleme ve izinlere aykırı faaliyetleri ve tanıtımları durdurmak da bulunmaktadır.

30 Konuya ilişkin bilgi için Mollahaliloğlu/Uğurlu/Kalaycı/Öztaş, s. 102 vd. 
akupunktur tedavisine yönelik yukarıda bahsi geçen yönetmelikler ${ }^{31}$ ise mülga olmuştur.

Sağlık Bakanlığı'nın ilgili yönetmeliği yayımlamasının, geleneksel ve tamamlayıcı tıp uygulamaları açısından oldukça faydalı bir gelişme olduğunu kabul etmek gerekir. Zira geleneksel ve tamamlayıcı tıp uygulamaları, günümüzde toplumda önem kazanmış ve toplumun merakını cezbetmiştir. Dolayısıyla bu alandaki boşluk ilgili yönetmelikle biraz olsun kapatılmaya çalışılmıştır. Nitekim bu alanın göz ardı edilmesi ve denetimsiz kalması halinde, toplum sağlığının riske girmesi kaçınılmazdır. Ancak ilgili yönetmelikte, yukarıda bahsi geçen konulara yer verilmekle birlikte, nedense bu uygulamaların hukuki yönüne ilişkin olarak genel hükümlere yapılan atıf dışında, herhangi özel bir hükme yer verilmemiştir. Sonuç olarak, Geleneksel ve Tamamlayıcı Tıp Uygulamaları Yönetmeliği'nde düzenlenen uygulamaların hukuka uygunluğunun değerlendirilmesinde kullanılabilecek özel şartlara anılan yönetmelikte yer verilmemiştir.

\section{Geleneksel ve Tamamlayıcı Tıp Uygulamaları Yönetmeliği Tarafından Kabul Edilen Tedavi Yöntemleri}

Dünya geneline bakıldığında, geleneksel ve tamamlayıcı tedavi yöntemlerinin yelpazesinin çok geniş olduğu görülmektedir. Bu bağlamda dünya genelinde uygulanan ve en çok bilinen geleneksel ve tamamlayıcı tıp uygulamaları şu şekilde sıralanabilir: Akupunktur, Aleksander Tekniği, Antroprofizik Tip, Toksinlerden Arındırıcı Diyetler (Detox), Aromaterapi, Ayurveda, Bio-feedback, Bitkisel Tip, Biyoenerji, Biyo-kimya, Hidroterapi, Hipnoz, Hirudoterapi, Homeopati, Kaplıca Tedavisi, Kayropratik, Kupa Tedavisi (Hacamat), Makrobiyotik, Masaj, Müzik Tedavisi, Natüropati, Negatif İyon Tedavisi, Ozon Tedavisi, Osteopati, Örüntü Tedavisi, Piramit Tedavisi, Psionik, Radyestezi, Radyonik, Refleksoloji, Reiki, Renk Tedavisi, Rolf Metodu, Tai Chi, Sesle Tedavi, Shiatsu, Şifacılık, Yoga/Meditasyon Egzersizleri en bilinen örneklerdir ${ }^{32}$.

Aslında anılan bu yöntemler ortaya çıktıkları dönemlerde tıbbın kendisini oluşturmakta iken, günümüzde geleneksel ve tamamlayıcı tıp uygu-

31 "20885 sayll Akupunktur Tedavi Yönetmeliği” ve "24879 say1l Akupunktur Tedavisi Uygulanan Özel Sağlık Kuruluşları ile Bu Tedavinin Uygulanması Hakkında Yönetmelik".

32 Bkz. Öztürk/Dömbekci/Ünal, s. 26; Tokaç, Mahmut: “Geleneksel Tıbba Akademik Yaklaşım: GETTAM”, Sağlık Düşüncesi ve Tıp Kültürü Dergisi, S. 28, Y. Eylül-EkimKasım 2013, s. 82 vd.; Erol, s. 31 vd.; Somer/Lutz, s. 61; Sarıyev, s. 35 vd. 
lamaları olarak adlandırılmaktadır. Ancak Sağlık Bakanlığı, bu uygulamalardan sadece on beşine Geleneksel ve Tamamlayıcı Tip Uygulamaları Yönetmeliği'nde yer vermiştir. Anılan on beş uygulama ise şunlardır: Akupunktur $^{33}$, Apiterapi ${ }^{34}$, Fitoterapi ${ }^{35}, \mathrm{Hipnoz}^{36}$, Sülük Uygulamasi ${ }^{37}$,

33 Akupunktur, günümüzde en yaygın kullanılan geleneksel ve tamamlayıcı tıp uygulamasıdır. Çin tıbbına göre, insan bedeninde akupunktur noktaları denilen bazı noktalar bulunmaktadır. Bu noktalar bazı araçların (iğne, lazer 1şınları, elektrik stimülasyonu, kupa, kulak için tohum, manyetik topçuklar, termik stimülasyon, akupres, ses, elektrik veya manyetik titreşimler) yardımıyla uyarılarak, vücudun kendi kendini tamir etmesi sağlanmaktadır. Konuya ilişkin ayrıntılı bilgi için bkz. Kavaklı, Ahmet: "Akupunktur", Fırat Tıp Dergisi, C. 15, S. 1, Y. 2010, s. 1 vd.; Kalyon, Tunç Alp: "Akupunktur Tedavisi”, Türk Fizyoterapi ve Rehabilitasyon Dergisi, C. 53, S. Özel Sayı 2, Y. 2007, s. $52 \mathrm{vd}$.

34 Bu uygulamada sadece bal arısından elde edilen bal, bal mumu, polen, propolis, arı sütü ve arı zehri gibi doğal ürünlerle kişilerin bağışıklık sisteminin güçlendirilmesi, böylece hastalıkların önlenmesi veya bir hastalık mevcutsa onun iyileştirilmesi amaçlanmaktadır, Konuya ilişkin ayrıntılı bilgi için bkz. Ulusoy, Esra: "Bal ve Apiterapi”, Uludağ Arıcılık Dergisi, Y. Ağustos 2012, C. 12, S. 3, s. 89 vd.; Aydın, Yıldıray/Tekeoğlu, İbrahim: "Tamamlayıcı Tip ve Güncel Apiterapi Uygulamaları", Journal of Biotechnology and Strategic Health Research, C. 2, S. 2, Y. 2018, s. 64 vd.

35 Kökeni Çin, Mısır ve Hindistan tıbbı olan fitoterapi, geleneksel reçetelerle ve bitkisel ilaçlarla gerçekleştirilen bir tedavi yöntemidir. Bilimsel araştırmalar da göstermiş̧ir ki; bitkilerin hastalıkların tedavisinde önemli bir potansiyeli bulunmaktadır. Fitoterapi, modern tıbbın karşısında yer almamakta, aksine modern tedavi yöntemlerinin tamamlayıcıs1 ve destekleyicisi durumundadır. Ancak fitoterapi tedavisinin bu tamamlayıc1 ve destekleyici fonksiyonunu tam anlamiyla yerine getirebilmesi, fitoterapi tedavisinde kullanılacak ürünlerin üretim sırasında ve sonrasında yetkili makamlarca kontrolünün gerçekleştirilmesine bağlıdır. Bitki bileşenlerinin ilaç olma safhasında klinik aşamalardan geçip geçmediği, güvenirliği, yan etkileri ve ruhsatlandırılması kontrol altında bulunmalıdır. Zira bu ürünlerin üretiminde kullanılan bitki bileşenlerinin türleri ve bunların dozajı önem arz etmekte olup, bunların yanlış kullanımı toksik etki de yaratabilir. Nitekim denetim eksikliği, bu tedavi yönteminin amacında sapmalara ve hastaların fiziksel veya zihinsel yönden zarar görmesine yol açabilir. Aynı şekilde insanların bu tip ilaçları kullanırken doğal ürünün yan etkisi olmaz yanılgısına düşerek, kontrolsüzce kullanması ve kendisini takip eden doktoruna bu hususta bilgi vermemesi de ayn sonuca neden olabilir. Konuya ilişkin ayrıntılı bilgi için bkz. Vardar, Deniz Özkan/ Mollahaliloğlu, Salih/Öztaş, Dilek: "Fitoterapide Kullanılan Bazı Fitokimyasalların Toplum Sağlığına Etkilerinin Değerlendirilmesi”, Journal of Health Sciences and Medicine, C. 1, S. 4, Y. 2018, s. 95 vd.; Yarıș, Ersin: "Molekülden İlaca Ama Bitkiden Nereye", Tibbın Alternatifi Olmaz!, Geleneksel, Alternatif ve Tamamlayıcı Tıp Uygulamaları, Türk Tabipleri Birliği Yayınları, Ankara 2017, s. 109 vd.; Yeşilada, s. 223 vd.; Şahin, Genel Bir Bakış, s. 159 vd.; Dişli, Meryem/Yeşilada, Erdem: "Türkiye'de Bitkisel Tıbbi Ürünler (Türkiye'de Bitkisel Ürünlerin Standardizasyonu, Üretimi ve Tağşiş)", Journal of Biotechnology and Strategic Health Research, C. 3, S. Özel Sayı, Y. 2019, s. 13 vd.; Tütüncü, s. 16 vd. 
Homeopati $^{38}$, Kayropraktik ${ }^{39}$, Kupa Uygulaması (Hacamat) ${ }^{40}$, Larva Uygulamasi $^{41}$, Mezoterapi ${ }^{42}$, Proloterapi ${ }^{43}$, Osteopati ${ }^{44}$, Ozon Terapi ${ }^{45}$, Refleksoloji $^{46}$, Müzik Terapi ${ }^{47}$.

36 Hipnoz, telkin yoluyla bir kişinin algılama, bilinç, hafıza, duygu ve davranışlarında meydana getirdiği değişiklikleri kapsayan sosyal etkileşim yöntemine denmektedir. İnsan zihni, bilinç ve bilinçaltı olarak iki kısımdan oluşur. İnsanlarda bilinç, yaşanılan ve deneyimlenen olayları değerlendirme, mantık yürütme ve karar verme mekanizması iken; bilinçaltı, duyguların, davranışların ve deneyimlerin yer aldı̆̆ı bölümdür. Bilinç, edinilen bilgiyi değerlendirmeden kabul etmemekte ve bilinçaltına her türlü bilginin yerleşmesine izin vermemektedir. İşte hipnoz sayesinde, zihnin bu iki kısmı arasındaki sınır kaldırılarak, bilincin bilgiyi kabul etmesi sağlanır. Yunan mitolojisinden adını alan hipnoz, binlerce yıl öncesinde dini ayinlerde kullanılan bir yöntem iken, ilk olarak medikal hipnoz 18. yy'da kullanılmaya başlanmış, özellikle 2. Dünya Savaşı'ndan sonra psikolojik travma geçiren kişilere uygulanması ile önem kazanmıştır. Konuya iliş̧in ayrıntılı bilgi için bkz. Ceyhan, Derya/Yiğit, Tuğba Tasa: "Tıbbi Tedavilerde Hipnoz Uygulamalarının Kullanımı ve Etkinliği”, Ankara Diş Hekimleri Odası Klinik Bilimler Dergisi, C. 7, S. 2, Y. 2013, s. 1507 vd.

37 Bu uygulamaya göre kan emici sülükler, insan vücudundaki hasta bölgeye konulmakta ve o bölgedeki kanı ağızlarından yaydıkları yararlı enzimlerle iyileştirmektedir. Doğada bulunan altı yüzden fazla sülük türünden sadece on beşinin medikal olarak kullanılabildiği bu uygulama, özellikle 19. yy'dan itibaren deri hastalıklarından kansere kadar birçok hastalığın tedavisinde kullanılmaktadır. Konuya ilişkin ayrıntılı bilgi için bkz. Ayhan, Hüseyin/Mollahaliloğlu, Salih: "Tıbbi Sülük Tedavisi: Hirudoterapi”, Ankara Medical Journal, C. 18, S. 1, Y. 2018, s. 141 vd.; Çelikbaş, Aysel Kocagül: "GATT Uygulamalarına Enfeksiyon Hastalıkları Açısından Yaklaşım”, Tıbbın Alternatifi Olmaz!, Geleneksel, Alternatif ve Tamamlayıcı Tıp Uygulamaları, Türk Tabipleri Birliği Yayınları, Ankara 2017, s. 226 vd.

$38 \mathrm{Bu}$ uygulamanın temelleri, Alman doktor Hahnemann tarafindan atılmıştır. Hahnemann'a göre, hastalıktan ziyade hastanın iç dünyasına odaklanılmalıdır. Zira hastalığın nedeni, insanın iç dünyasında yatmaktadır. Her hastanın kendine ait bir yaşamı ve bu yaşam içerisinde alışkanlıkları, zihni ve o zihinle yarattığı duyguları vardır. Dolayısıyla aynı hastalık, iki farklı kişide, farklı nedenlere dayanabilir. Çünkü bu kişilerin bireysel özellikleri farklıdır ve her bir hastaya farklı dozlarda ilaç verilmelidir. Konvansiyonel tıp uygulamalarında ise, hastadan ziyade hastalık dikkate alınır ve aynı hastalığa sahip kişilere aynı dozlarda aynı tedavi yöntemi (aynı ilaç, aynı tıbbi cihaz kullanımı gibi) verilerek hastalık iyileştirilmeye çalışılır. Homeopati, özellikle Avrupa, Hindistan, Japonya ve Kanada'da yaygın olarak kullanılan tamamlayıcı tıp uygulamasıdır. Konuya ilişkin ayrıntılı bilgi için bkz. Buda, Levent: Bir Tedavi Sanatı: Homeopati, Homeopatik Ev Eczanesi, 2. Bask1, A7 Kitap Yayıncılık, İstanbul 2018, s. 23 vd.; Helmstädter, Axel: "Hahnemann und die Homöopathie: Alternativ seit 250 Jahren”, PharmR, Heft 1, S. 13, Y. 2006, s. 13 vd.; Böttger, Ralf/Kirchner, Christiane: Arzneimittelrecht, Handbuch für die Rechtspraxis (Hrsg.: Fuhrmann, Stefan/Klein, Bodo/Fleischfresser, Andreas), 3. Auflage, Nomos, Baden-Baden 2020, § 4, Rn. 10 vd.

39 Kayropraktik ise; kas, omurga ve iskelet sistemindeki biyomekanik bozukluklarla ve bu bozuklukların sinir sistemi üzerindeki etkileri (özellikle sırt ve bel ağrıları gibi) önlemekle ilgilenen tamamlayıcı tıbbi bir uygulamadır. Elle tedavi yöntemi olan bu uygu- 
lama; ABD, Kanada ve bazı Avrupa ülkelerinde yasalarla desteklenerek yaygın bir biçimde kullanılır hale gelmiştir. Hatta ABD, İngiltere ve İsviçre'de kayropraktik uygulamalarına ilişsin sağlık harcamaları devlet tarafından karşılanmaktadır. Konuya ilişkin ayrıntılı bilgi için bkz. Taneri, Petek Eylül/Akış, Nalan: "Geleneksel, Alternatif ve Tamamlayıcı Tip Yöntemleri”, Tibbın Alternatifi Olmaz!, Geleneksel, Alternatif ve Tamamlayıcı Tıp Uygulamaları, Türk Tabipleri Birliği Yayınları, Ankara 2017, s. 72 vd.

40 Kupa tedavisi, top ve çan gibi farklı şekil ve boyutlardaki kupalarla kan dolaşımını artırarak bölgesel vakum oluşturmaya dayanan kuru kupa uygulaması ve bölgesel vakumla birlikte yüzeysel cilt kesikleri oluşturarak, bölgedeki sıvının dışarı atılmasına dayanan yaş kupa uygulamasından oluşmaktadır. Günümüzde Uzakdoğu, Orta Doğu, Arabistan Yarımadası ve Orta Avrupa ülkelerinde yaygın olarak kullanılmaktadır. Konuya ilişkin ayrıntılı bilgi için bkz. Okumuş, Müyesser: "Kupa Tedavisi ve Hacamat", Ankara Medical Journal, C. 16, S. 4, Y. 2016, s. 370 vd.

$41 \mathrm{Bu}$ tedavi yönteminde, steril Lucilia Sericata cinsi sinek larvaları, yaralı bölgeye uygulanmaktadır. Larvalar gezindikleri bölgede oluşturdukları mekanik etkiyle kronik yaraları uyararak, onların iyileşmesini sağlamaktadır. Konuya ilişkin ayrıntılı bilgi için bkz. Tanyüksel, Mehmet/Koru, Özgür/Araz, Remzi Engin/Kılbaş, Hatice Zeynep Güçlü/Yıldız, Şenol/Alaca, Rıdvan/Ay, Hakan/Şimşek, Kemal/Yıldız, Cemil/Yurttaş, Yüksel/Demiralp, Bahtiyar/Deveci, Mustafa/Beşirbellioğlu, Bülent A.: "Kronik Yaraların Tedavisinde Steril Lucilia Sericata Larva Uygulamaları", Gülhane Tıp Dergisi, C. 56, S. 4, Y. 2014, s. 218 vd.

42 Özellikle Avrupa'da uzun yıllardır deri lezyonlarında, yaşlanma karşıtı çalışmalarda, fizik tedavide, ortopedide, saç dökülmelerinde ve spor hekimliği alanında kullanılan mezoterapi, bitkisel veya farmakolojik ilaçların gerekli ise seyreltilmiş bir biçimde patolojinin bulunduğu bölgeye çoklu enjeksiyonlarının belirli aralıklarla özel iğnelerle cilt altına uygulanmasıdır. Konuya ilişkin ayrıntılı bilgi için bkz. Atalık, Ahmet: "Mezoterapi ve Klinik Uygulamalar", Journal of Biotechnology and Strategic Health Research, C. 3, S. Özel Say1, Y. 2019, s. 115 vd.

43 Çoğunlukla kronik ağrıları olan hastalarda kullanılan bu tamamlayıcı tıbbi yöntemde, proliferatif solüsyonlar sorunlu bölgedeki bağ dokusu içine steril özel iğnelerle enjekte edilerek, o bölgede oluşan inflamasyona karșı vücudun savunma mekanizması devreye sokulmaya çalışılır. Konuya ilişkin ayrıntılı bilgi için bkz. Yaman, Hakan/Vural, Ramazan: "Proloterapi: Aile Hekimliği'nde Kronik Ağrı Yönetiminde Yeni Bir Yöntem”, Ankara Medical Journal, C. 16, S. 2, Y. 2016, s. 220 vd.

44 Kas ve iskelet sistemi hastalıklarında (genellikle bölgesel kronik ağrılarda) konvansiyonel tıbbın yanında, onu tamamlayıcı nitelikte kullanılan ve el ile gerçekleştirilen bu yöntemde, sağlık problemi bölgesel dahi olsa, bölgesel problem tüm bedenin bütünlüğü içerisinde tedavi edilmeye çalışılır. Çünkü bu tedavi yöntemine göre, bölgesel sağlık problemleri, bedenin başka bir bölgesindeki veya organdaki mekanik dengesizlikten kaynaklanıyor olabilir. Konuya ilişkin ayrıntılı bilgi için bkz. Kaya, Elif/Altınbilek, Turgay: "Osteopati Yaklaşımı; Bel ve Boyun Ağrılarında Yeri”, Journal of Biotechnology and Strategic Health Research, C. 3, S. Özel Say1, Y. 2019, s. 85 vd.

45 Ozon ve oksijen karışımı maddenin vücut boşluklarına veya dolaşım sistemine uygulanması olarak tanımlanan ozon terapi, bağışıklık sisteminin güçlendirilmesinde, romatizmal hastalıkların, diş hastalıklarının tedavisinde, kanserli hastaların yaşam kalitelerinin artırılmasında, sporcuların performansının artırılmasında ve hatta Covid19'un tedavisinde, konvansiyonel tıbbın yanında onu destekleyici olarak kullanılan 
Geleneksel ve Tamamlayıcı Tıp Uygulamaları Yönetmeliği’nde anılan bu uygulamaların, hangilerinin geleneksel veya hangilerinin tamamlayıcı tıp uygulaması olduğuna ilişkin bir belirleme söz konusu olmamaktadır. Bununla birlikte, ilgili hükümlerin değerlendirilmesi sonucunda; Akupunktur, Apiterapi, Hipnoz, Sülük Uygulamas1, Homeopati, Kayropraktik, Kupa Uygulamas1, Larva Uygulamas1, Mezoterapi, Proloterapi, Osteopati, Ozon Terapi, Refleksoloji ve Müzikterapi uygulamalarının, sadece konvansiyonel tıp uygulamalarını destekleyici ve bütünleyici olarak kullanılması öngörüldüğünden, bunları tamamlayıcı tıp uygulamaları olarak kabul etmek uygun görünmektedir. İlgili yönetmeliğe göre fitoterapi ise, geleneksel bitkisel tıbbi ürünler ve bitkisel ilaçlarla yapılan tıbbi bir tedavi yöntemi olarak tanımlandığı için, geleneksel tıp niteliğini haiz olduğu söylenebilir.

\section{GELENEKSEL VE TAMAMLAYICI TIP UYGULAMA- LARININ HUKUKA UYGUNLUĞUNUN TESPITI}

\section{A. Genel Olarak}

Geleneksel ve tamamlayıcı tıp uygulamaları, çoğunlukla konvansiyonel tıp uygulamaları tarafından kabul görmemiş, bilimsel olarak yeterince denenmemiş, fayda ve risk değerlendirmesinin yapılmasının daha zor olduğu

tamamlayıcı tıbbi bir yöntemdir. Konuya ilişkin ayrıntılı bilgi için bkz. İkizek, Mustafa/Uzuntarla, Yasin: "Medikal Ozon Tedavisi ve Covid-19", Sağlık Akademisyenleri Dergisi, C. 7, S. 4, Y. 2020, s. 304 vd.; Aytaçoğlu, Saltuk: “Ozon Terapi”, Ankara Akupunktur ve Tamamlayıcı Tip Dergisi, S. 1, Y. 2014, s. 31 vd.

46 Refleksolojiye göre; kulaklar, eller ve ayaklardaki bazı refleks noktaları, organlar, salg1 bezleri ve diğer vücut bölümleri ile ilişki içerisindedir. Dolayısıyla bu noktaların herhangi bir cihaz, malzeme, krem, losyon kullanmadan uygulanan basınçla uyarılması sonucunda vücuttaki enerji dengelenir ve vücut fonksiyonları normalleştirilebilir. Konuya iliş̧in ayrıntılı bilgi için bkz. Kıvan, Çevik: "Hemşirelikte Tamamlayıcı ve Alternatif Tedavi: Refleksoloji”, Ege Üniversitesi Hemşirelik Fakültesi Dergisi, C. 29, S. 2, Y. 2013, s. $71 \mathrm{vd.}$

47 Özellikle Kronik Şizofreni, Parkinson ve Alzheimer hastaları üzerinde pozitif etkileri olan müzik terapi, aslında ülkemiz için geleneksel tıbbi bir uygulamadır. Zira bu yöntem, 1850 yıllarına değin Anadolu coğrafyasında yaklaşık bin yıl kadar uygulanmış, sonrasında ise bir süreliğine terk edilmiştir. Ancak 2000 yılından sonra yapılan çalışmalar sayesinde varlığını ve etkinliğini tekrardan kazanmıştır. Dolayısıyla bu uygulama, ülkemiz açısından geleneksel bir yapıya sahiptir. Bu uygulamaya göre, hastaların fiziksel, psikolojik, sosyal ve zihinsel ihtiyaçları müzik terapisi konusunda eğitim almış profesyonel kişiler tarafından tespit edilir ve bu doğrultuda tedavi uygulanır. Konuya ilişkin ayrıntılı bilgi için bkz. Öztürk, Levent/Özbek, Hanefi: "Küllerinden Doğan Bir Tıbbi Uygulama: Müzik Terapi”, Sağlık Hizmetleri ve Eğitimi Dergisi, C. 2, S. 1, Y. 2018, s. 1 vd.; Şahin, Genel Bir Bakış, s. 162. 
tedavi yöntemleri olmaları sebebiyle, uygulanmaları halinde doktorun hukuki sorumluluğunun doğması, konvansiyonel tıp uygulamalarına nazaran daha muhtemeldir.

Kural olarak her türlü tıbbi müdahale, her şeyden önce vücut dokunulmazlığının ihlali anlamına gelmekte ve vücut dokunulmazlığına karşı yapılan her türlü ihlal, kişilik haklarına saldırı teşkil etmektedirr ${ }^{48}$. Dolayısıyla tıbbi müdahaleler, özel hukuk anlamında bir haksız fiil teşkil edebilir. Türk Borçlar Kanunu ${ }^{49}$ m. 49/f. 1 uyarınca hukuka aykırılık, zarar, kusur ve illiyet bağı haksız fiilin kurucu unsurlarıdır. Başkasının vücut dokunulmazlığının ihlali, temel koruma normları ile doğrudan doğruya korunan hukuki varlıkların ihlali olması sebebiyle, hukuka aykırılık teşkil eden hallerden biridir. Ancak vücut dokunulmazlığını ihlal eden kişinin bu şekilde davranmasına hukuk normu izin vermekteyse, bu davranış hukuka uygun bir davranıştır. Hukuka uygunluk sebeplerinin varlığı halinde, o davranış başından itibaren hukuka uygun bir davranış olup, hiçbir zaman hukuka aykırı olmaz $^{50}$. Tibbi müdahalelerin hukuka uygunluğunun tespitinde ise, standart tedavi ilkeleri doğrultusunda değerlendirme yapılmaktadır ${ }^{51}$. Bunlar, tıbbi müdahalenin yetkili kişi tarafından gerçekleştirilmesi, aydınlatma ve rıza, tıbbi gereklilik, tıbbi standart olarak sayılmaktadır ${ }^{52}$. Bu şartların varlı̆̆ halinde yapılan her türlü tıbbi müdahale, hukuka uygun olarak değerlendirilmekte ve uygulayıcı için hukuki sorumluluğun doğması söz konusu olmamaktadır. Geleneksel ve tamamlayıcı tıp uygulamalarının hukuka uygunluğunun değerlendirilmesi noktasında, Geleneksel ve Tamamlayıcı Tıp

48 Karş. BGH, NJW 1956, 1106 vd.; BGH NJW 1980, 1905 vd.; BGH NJW 1994, 127 vd., $<$ https:// beck-online.beck.de > E.T.: 13.01.2021.

$49 \quad 04.02 .2011$ tarihli 27836 sayılı Resmi Gazete'de yayınlanmıştır.

50 Konuya ilişkin ayrıntılı bilgi için bkz. Eren, Fikret: 6098 Sayılı Türk Borçlar Kanununa Göre Hazırlanmış Borçlar Hukuku Genel Hükümler, 15. Bask1, Yetkin Yayınları, Ankara 2013, s. 516 vd.; Antalya, Gökhan: 6098 Sayılı Türk Borçlar Kanununa Göre Borçlar Hukuku Genel Hükümler, C. 1, Beta Yayınları, Ankara 2012, s. 425 vd.

51 Konuya ilişkin Yargıtay kararına göre, "Sorumsuzluktan yararlanabilmek için tıp sanatının kurallarına, gereken tedbirlere uymak ve bu sınırlar içinde hareket etmek gereklidir. Diğer bir deyimle şayet tıp ilmi hekimin yaptığ müdahalelere cevaz veriyorsa, bunu yapan hekim, tıp mesleğince tecviz edilen bir faaliyette bulunmuş demektir ki, hakkın icrası nedeniyle, eylemi hukuka aykırı sayllamaz.", Y4HD., 07.03.1977 T., 1976/6297 E., 1977/12541 K., <https://www.kazancihukuk.com> E.T.: 05.04.2021.

52 Karş. Hakeri, Tıbbi Müdahalenin Hukuka Uygunluğunun Şartları”, Legal Tıp Hukuku Dergisi, C. 3, S. 6, Y. Ekim 2014, s. 18 vd.; Özer, Oktay: "T1bbi Müdahalenin Hukuka Uygunluğunun Şartları”, İstanbul Barosu Dergisi, C. 90, S. 5, Y. Eylül-Ekim 2016, s. 119 vd.; Akyıldız, Sunay: "Tıbbın Uygulanmasından Doğan Tazminat Davaları ve Temel Unsurları”, Legal Tip Hukuku Dergisi, C. 1, S. 1, Y. Nisan 2012, s. 206 vd. 
Uygulamaları Yönetmeliği'nde konuya ilişkin özel düzenlemeler mevcut değildir. Ancak ilgili yönetmelikte anılan uygulamalar, aşağıda değinileceği üzere, birer tıbbi müdahale teşkil etmeleri sebebiyle, bahsi geçen standart tedavi ilkeleri, burada da hukuka uygunluğun tespiti açısından geçerlidir. Bununla birlikte, geleneksel ve tamamlayıcı tıp uygulamalarının kendine has özellikleri sebebiyle, anılan ilkelerin içeriği konvansiyonel tıbbi müdahalelere nazaran bazı durumlarda farklılaşabilmektedir. Dolayısıyla geleneksel ve tamamlayıcı tıp uygulamalarının hukuka uygunluğunun tespiti bakımından aydınlatma, rıza, tıbbi gereklilik ve tıbbi standart şartlarına ilişkin ayrı ve açık hükümlerin konulması ihtiyacı bulunmaktadır.

Geleneksel ve tamamlayıcı tıbbi uygulamalardan doğan hukuki sorumluluğun çıkış noktası (kaynağı), doktorun tedavi yöntemi seçme özgürlügüdür (Therapiefreiheit). Ancak doktorun bu takdir yetkisi, onun kararlarında tamamen özgür olduğu anlamına gelmemektedir. Zira tedaviyi seçme özgürlüğ̈̈, doktorun bir ayrıcalığı olarak değil, başkası yararına bir hak (ein fremdnütziges Recht) olarak anlaşılmalıdır ${ }^{53}$. Doktorun tedaviyi seçme özgürlügünün merkezinde, çoğu zaman hasta yer almaktadır ve doktor karar verirken, hastanın iradesi kadar onun faydasını da gözetmelidir. Doktorun karar verme özgürlügünün sınırlarını, hastanın yararı ve rızası çizmektedir. Hastanın hukuka uygun rızasının alınmış sayılabilmesi ise, doktorun aydınlatma yükümlülügünü yerine getirmiş olmasına bağlıdır. Dolayısıyla tedavi yönteminin seçimi noktasında, doktor ve hasta işbirliği içerisinde hareket etmelidir ${ }^{54}$.

Doktorun tedavi yöntemi seçimi noktasındaki takdir yetkisi, geleneksel ve tamamlayıcı tıp uygulamalarını da kapsar. Bu bağlamda geleneksel ve tamamlayıcı tıp yöntemlerinin uygulanması noktasında herhangi hukuki bir engel konulamaz ${ }^{55}$. Doktorun hastalığın tedavisinde geleneksel ve tamam-

53 Schmid, Hugo: "Die Grenzen der Therapiefreiheit", NJW, Heft 38, Y. 1986, s. 2339 vd.; Schumacher, Katrin: "Arzthaftungsrecht aus alternativmedizinischer Sicht”, MedR, S. 37, Y. 2019, s. 787 vd.

54 Schmid, s. 2339 vd.; Schumacher, Arzthaftungsrecht, s. 787 vd.

55 Ayrıca böyle bir engelin mevcudiyeti halinde, hastanın kendi kaderini tayin hakkı (Selbstbestimmungsrecht des Patienten) da elinden alınmış sayılır. Yargıtay'ın konuya ilişkin bir kararına göre, "Kişiler kendi vücutları üzerinde ayrık durumlar hariç, ancak kendileri tasarrufta bunabilir ve tehlikelere karşı yine kendisi karar verebilir. Tibbi müdahalelerde de bu genel kuraldan ayrlmamak gerekir. Tibbi müdahaleler ve hekimin girişeceğ tehlikeleri meydana getirici nitelikte olduğu için, bunların gerçekleştirilmesine karar verme yetkisi hekime değil, müdahalelere maruz kalacak kişiye (hastaya) aittir.”, 
layıcı tıp yöntemlerinden birini seçmesi, hukuki aykırılığın doğması için tek başına yeterli bir kıstas değildir. Zira tedavi yöntemlerinin seçimi noktasında, doktorun özgürlüğü bulunmaktadı5 ${ }^{56}$. Hukuka aykırılı̆̆ın doğması, doktorun tedavi yöntemi seçimindeki hatasından ileri gelebileceği gibi, aydınlatma yükümlülüğünün ve uygulama sırasında veya sonrasındaki özen yükümlülügünün ihlalinden ileri gelebilir.

Tıp bilimi sürekli gelişen bir bilim dalıdır. Dolayısıyla henüz tanınmayan bir tedavi yöntemi, yarın standart prosedür olarak karşımıza çıkabilir. Ancak geleneksel ve tamamlayıcı tıp uygulamalarından doğan her türlü hukuki sorumluğun, yeni tıbbi uygulamalardan doğan hukuki sorumluluk kapsamında değerlendirilmemesi gerekmektedir. Elbette ki, geleneksel ve tamamlayıcı tıp uygulamaları, bazı hallerde yeni tıbbi gelişme olarak da kabul edilebilir ve konvansiyonel tıp tarafından kabul görmeye başlayabilir. Geleneksel ve tamamlayıcı tıp uygulaması sayılan bir yöntem, bilimsel testlere ve araştırmalara konu olduğunda bu durum söz konusudur. Bilimsel araştırmalar sonucunda, aslında yeni olmayan bir geleneksel ve tamamlayıcı tıp uygulaması, konvansiyonel tıp tarafından daha sonra tanınabilir. Böylece geleneksel ve tamamlayıc tıp uygulaması, yeni bir muayene veya tedavi yöntemi (Neulandmethode) olarak karşımıza çıkabilir ${ }^{57}$.

\section{B. Geleneksel ve Tamamlayıcı Tıp Uygulamalarının Hukuka Uygun Sayılabilmesi İçin Gerekli Şartlar}

Hasta Hakları Yönetmeliği ${ }^{58}$ m. 4/g bendi uyarınca tıbbi müdahale, "ttp mesleğini icraya yetkili kişiler tarafindan uygulanan, sağlı̆̆ koruma, hastalıkların teşhis ve tedavisi için ilgili meslekî yükümlülükler ve standartlara uygun olarak tıbbın sınırları içinde gerçekleştirilen fizikî ve ruhî girişimlerdir". Biyotıp Araştırmalarına İlişkin İnsan Hakları ve Biyotıp Sözleşmesine Ek Protokol ${ }^{59}$ m. 2/f. 3'e göre "müdahale" ifadesi, fiziksel müdahale ve ilgili kişinin psikolojik sağlı̆g 1 açısından risk taşıyan herhangi bir müda-

Y4HD., 07.03.1977 T., 1976/6297 E., 1977/12541 K., <https://www.kazancihukuk. com> E.T.: 05.04.2021.

56 Schubarth, Martin: "Therapiefreiheit des Arztes und Selbstbestimmungsrecht des Patienten Konsequenzen für das Arztstrafrecht und die formula magistralis", AJP, S. 9, Y. 2007, s. 1089 vd., <http://swisslex.ch> E.T.: 15.01.2021; OLG Koblenz, NJW, 1996, 1600 vd., <https://beck-online.beck.de > E.T.: 13.01.2021.

57 Schumacher, Arzthaftungsrecht, s. 787; Schubarth, s. 1091 vd.

$58 \quad 01.08 .1998$ tarihli 23420 sayılı Resmi Gazete'de yayınlanmıştır.

$59 \quad 11.06 .2011$ tarihli 27961 sayılı Resmi Gazete'de yayınlanmıştır. 
hale anlamında kullanılmaktadır. Yargıtay'a göre ${ }^{60}$ ise tıbbi müdahale, tıp biliminin kuralları uygulanmak suretiyle yapılan her türlü müdahaledir.

İlgili tanımlar göz önünde bulundurularak yapılabilecek tanıma göre tıbbi müdahale, tıp mesleğini yapmaya yetkili bir kişi tarafindan mesleki bilgisi dahilinde, sağlıklı bir kişinin sağ 1 ğını korumak veya hasta bir kişinin hastalığını tedavi etmek amacıyla, o kişinin bedensel ve ruhsal bütünlüğune yönelik doğrudan veya dolaylı olarak gerçekleştirilen her türlü müdahaledir ${ }^{61}$.

Bu tanımdan hareketle, bir müdahalenin tıbbi müdahale sayılabilmesi için gerekli unsurlar şu şekilde sıralanabilir: İlk olarak; müdahalenin yetkili kişi (doktor) tarafından gerçekleştirilmesi şarttır. Ancak doktor tarafından yapılmasa dahi, doktorun denetim ve gözetimi altında, yardımcı sağlık meslek mensuplarının ilk ve acil yardım müdahaleleri de tıbbi müdahale kapsamındadır. İkinci olarak; müdahale, doğrudan doğruya veya dolaylı olarak hastayı tedavi amacına yönelik olmalıdır. Son olarak, ilgili müdahale, müdahaleyi gerçekleştiren kişinin mesleki bilgisi dahilinde gerçekleştirilmelidir. Dolayısıyla Geleneksel ve Tamamlayıcı Tıp Uygulamaları Yönetmeliği’nce sayılan on beş geleneksel ve tamamlayıcı tıp uygulaması tıbbi müdahale kapsamı içerisinde kabul edilmelidir ${ }^{62}$. Zira ilgili yönetmelikçe, geleneksel ve tamamlayıcı tıbbi uygulamayı gerçekleştiren kişi, sertifikaya sahip doktor ve kendi alanıyla sınırlı olmak üzere diş hekimi veya doktor gözetimi altında uygulama alanında sertifikası bulunan yardımcı sağlık meslek mensubu olmalıdır. Ayrıca bu uygulamalar kapsamında yapılan müdahaleler, doğrudan doğruya veya dolaylı olarak hastanın fiziksel ve ruhsal sağlığını korumak veya mevcut hastalıkları iyileştirmek amacıyla gerçekleştirilmektedir. T1bbi müdahaleler, vücut bütünlügüne yönelik fiiller olabileceği gibi, vücut bütünlügüne dokunmamakla birlikte, fiziksel ve zihinsel sağlığı korumaya yönelik fiillerden de oluşabilir. Nitekim ilgili yönetmelikçe kabul edilen çoğu uygulama, kişinin vücut bütünlüğüne yönelik fiiller içermektedir. Özellikle akupunktur, mezoterapi, proloterapi, ozon terapi, sülük, kupa ve

60 Y2HD., 07.04.2014 T., 2014/33 E., 2014/8131 K. <https://www.legalbank.net> E.T.: 13.01.2021; Y2HD., 03.03.2014 T., 2013/21336 $\quad$ E., 2014/4508 K., $<$ https://www.kazancihukuk.com> E.T.: 13.01.2021.

61 Konuya ilişkin ayrıntılı bilgi için bkz. Özgül, Mehmet Emin: Yeni Tıbbi Yöntemlerin Hukuka Uygunluğu, On İki Levha Yayıncılık, İstanbul 2010, s. 5 vd.

62 Taşçı, Ali İhsan: "Adli Tıp Penceresinden Alternatif Tıp Uygulamaları", Sağlık Düşüncesi ve Tıp Kültürü Dergisi, S. 22, Y. Mart-Nisan-Mayıs 2012, s. 50; Konuya ilişkin ayrıntılı bilgi için bkz. Sarıyev, s. 11 vd.; Ayan, Mehmet: Tıbbi Müdahalelerden Doğan Hukuki Sorumluluk, Kazancı Yayınları, Ankara 1991, s. 5 vd. 
larva uygulamasında kişinin deri bütünlüğü bozulmaktadır ${ }^{63}$. Ancak müzik terapi, daha çok kişinin bedeni ve ruhi sağlığına yönelik tıbbi müdahale niteliğindedir. Son olarak ilgili müdahaleler, bu yönde yetkili kişiler tarafından mesleki bilgileri (eğitim ve sertifika) dahilinde yapılmaktadır. Ayrıca ilgili yönetmelikçe kabul edilmiş uygulamalar, diğer geleneksel ve tamamlayıcı tıp uygulamaları ile karşılaştırıldığında, tıp çevreleri tarafından daha fazla kabul görmüş olan uygulamalardır ${ }^{64}$.

Ancak Geleneksel ve Tamamlayıcı Tıp Uygulamaları Yönetmeliği'nce sayılan on beş geleneksel ve tamamlayıcı tıp uygulaması dışında kalan uygulamalar, tıbbi müdahale kapsamında değildir. Zira bu uygulamaların (Aromaterapi, Ayurveda, Masaj, Reiki, Yoga/Meditasyon gibi) başta doktor, diş hekimi veya onların gözetiminde yardımcı sağlı personelince gerçekleştirilme zorunluluğu bulunmamaktadır. Nitekim yönetmelik kapsamına alınmayan geleneksel ve tamamlayıcı tıbbi uygulamaların, doktor veya diş hekimi dışındaki kişiler tarafından uygulanmasını engelleyen mevcut bir düzenleme bulunmamaktadır. Ayrıca ilgili uygulamalar, doğrudan veya dolaylı hastayı tedavi amacıyla değil, daha çok kişileri terapi amaçlıdır. $\mathrm{Bu}$ uygulamalar sayesinde kişiler, fiziksel, zihinsel ve sosyal yönden tam bir iyilik haline kavuşturulmaktadır. Sonuç olarak, doktor tarafindan uygulanma zorunluluğu bulunmayan ve tedaviden çok terapiye yönelik geleneksel ve tamamlayıcı tıp uygulamaları (Yoga/Meditasyon gibi), tıbbi müdahale olarak kabul edilmemelidir ${ }^{65}$. Bu uygulamaların özel hukuk bağlamında hukuka uygun olup olmadıkları, genel hükümler (somut şartlara göre haksız fiil veya sözleşmesel sorumluluk) çerçevesinde ele alınmalıdır. Bu uygulamalar,

63 Konuya ilişkin bilgi için bkz. Toptan, Hande/Kaya, Tuğba/Altındiş, Selma: "Geleneksel ve Tamamlayıcı Tıp (GETAT) Uygulamalarında Enfeksiyon Kontrol Önlemleri, Hijyen ve Çalışan/Hasta Güvenliğì", Journal of Biotechnology and Strategic Health Research, C. 3, S. Özel Say1, Y. 2019, s. 168 vd.; Şahin, Genel Bir Bakış, s. 160; Tütüncü, s. 20; Ayhan/Mollahaliloğlu, s. 141 vd.; Çelikbaş, s. 224 vd.; Tamam, Cüneyt/Tamam, Yusuf: "Farklı Bir Bozucu Alan Nedeni: Hacamat", Bilimsel Tamamlayıc1 Tıp Regülasyon ve Nöral Terapi Dergisi, C. 12, S. 1, Y. 2018, s. 26 vd.; Atalık, s. 115 vd.; Yaman/Vural, s. 220 vd.; Aytaçoğlu, s. 31 vd.; İkizek/Uzuntarla, s. 304 vd.

64 Karş. Atalık, s. 116 vd.; Aydın, s. 8 vd.; Aydın/Tekeoğlu, s. 64 vd.; Ayhan/ Mollahaliloğlu, s. 141 vd.; Aytaçoğlu, s. 31 vd.; Biçer/Balçık, s. 245 vd.; Buda, s. 23 vd.; Ceyhan/Yiğit, s. 1507 vd.; Civaner, s. 9 vd.; Dişli/Yeşilada, s. 13 vd.; İkizek/ Uzuntarla, s. 304 vd.; Kalyon, s. 52 vd.; Kavaklı, s. 1 vd.; Kaya/Altınbilek, s. 85 vd.; Okumuş, s. 370 vd.; Öztürk/Özbek, s. 1 vd.; Şahin, Genel Bir Bakış, s. 159 vd; Tamam/Tamam, s. 26 vd.; Tanyüksel/Koru/Araz/Kılbaş/Yıldız/Alaca/Ay/Şimşek/ Yıldız/Yurttaş/Demiralp/Deveci/Beşirbellioğlu, s. 218 vd.; Yaman/Vural, s. 220 vd. 65 Konuya ilişsin ayrıntılı bilgi için bkz. Sarıyev, s. 11 vd.; Özgül, s. 5 vd. 
çalışmanın kapsamına dahil değildir. Aşağıda yer alan bilgi ve değerlendirmeler, her biri bir tıbbi müdahale teşkil eden ve Sağlık Bakanlığı'nca düzenlenen on beş geleneksel ve tamamlayıcı tıbbi uygulamanın hukuka uygunluğunun tespitine ilişkindir.

Konvansiyonel tıbbi müdahalelere nazaran, geleneksel ve tamamlayıcı tıbbi müdahalelerin risklerinin tespitinin güç olması ve yeterince denenmemiş olmaları sebebiyle, tıbbi müdahalelerin hukuka uygunluğunun tespiti açısından öngörülen genel (standart) prensiplerin içeriği farklılıklar taşıyabilmektedir. Bu yüzden öncelikle, tıbbi müdahalelere ilişkin standart prensiplerin genel tanım ve açıklanmasına yer verilecek olup, ardından geleneksel ve tamamlayıcı tıbbi müdahalelere ilişkin bazı ayrık durumlara değinilerek, bunların hukuka uygunluğu için gereken özel şartlar değerlendirilmeye çalışılacaktır.

\section{Tıbbi Müdahalede Yetkili Kişi}

\section{a. Genel Olarak}

Her türlü tıbbi uygulama yapma (müdahale) yetkisi, içerisinde barındırdığı riskler dolayısıyla, kural olarak sadece sağlık personeline verilmiştir. Yetkili sağlık personeli dışında gerçekleştirilen her türlü tıbbi müdahale, vücut bütünlügünün ihlali sayılır ve vücut bütünlügüne karş1 yapılan her türlü ihlal kişilik haklarına saldırı teşkil etmektedir. Yetkili sağlık personeli ise doktor veya diş hekimidir ${ }^{66}$.

Diş hekimi veya doktor dışındaki sağlık meslek mensuplarının doğrudan tıbbi müdahalede bulunmaları söz konusu değildir. Bu kişiler (ebeler, sünnetçiler, hemşireler, intörn hekimler) ancak diş hekimi veya tıp dokto-

661219 sayılı Tababet ve Şuabatı San'atlarının Tarzı İcrasına Dair Kanun m. 1 uyarınca, Türkiye'de hekimlik yapabilmek için tıp fakültesinden mezun olmak şarttır. Dolayısıyla yetkili sağlık personeli, tıp fakültesi veya diş hekimliği fakültesi diplomasına sahip kişilerdir. Ancak diş hekimi, sadece kendi alanıyla sınırlı olmak üzere tıbbi müdahalede bulunabilir. Zira ilgili kanunun 29. maddesine göre diş hekimi, insan sağlığına ilişkin olarak, dişlerin, diş etlerinin ve bunlarla doğrudan bağlantılı olan ağız ve çene dokularının sağlığının korunması, hastalıklarının ve düzensizliklerinin teşhisi, tedavisi ve rehabilite edilmesi ile ilgili her türlü mesleki faaliyeti icra etmeye yetkilidir. Diş hekimliğinin herhangi bir dalında münhasıran uzman olmak ve o unvanı ilan edebilmek için diş hekimliği fakültelerinden veya Sağlık Bakanlığına bağlı eğitim kurumlarından alınmış bir uzmanlık belgesine sahip olmak şarttır. Bununla birlikte hem tıp doktorlarının, hem de diş hekimlerinin, Türk vatandaşı olması şartı aranmamaktadır. Dolayısıyla yabancı uyruklu kişiler de Sağlık Bakanlığı'ndan onay ve Çalışma ve Sosyal Güvenlik Bakanlığı'ndan çalışma izni almaları şartıyla hekimlik yapabilirler. 
runun gözetim ve denetimi altında, dolaylı olarak tıbbi müdahalede bulunabilirler. Ancak bu kuralın istisnası bulunmaktadır. Buna göre, diş hekimi veya tıp doktoru dışında yer alan sağlık meslek mensupları (1219 sayılı Tababet ve Şuabatı San'atlarının Tarzı İcrasına Dair Kanun Ek fikra: 21.06.2005-5371/m. 7 uyarınca), sadece ilk yardım veya acil tıbbi müdahale gerektiren hallerde, doğrudan tıbbi müdahalede bulunabilirler ${ }^{67}$.

\section{b. Geleneksel ve Tamamlayıcı Tıp Uygulamalarında Yetkili Kişi}

Geleneksel ve Tamamlayıc Tıp Uygulamaları Yönetmeliği’nde ilk defa bu uygulamaların kimler tarafından gerçekleştirilebileceği, bu kişilerin asgari eğitimleri, uygulama merkezlerinin niteliği ve standardı belirlenmiştir. Buna göre, ilgili yönetmelikle sayılan on beş geleneksel ve tamamlayıcı tıp uygulamas1, sadece uygulama sertifikasına sahip doktorlar ve sadece kendi alanlarıyla sınırlı olmak üzere yine uygulama sertifikasına sahip diş hekimleri tarafından yerine getirilmelidir ${ }^{68}$. Böylece ilgili yönetmelik dışında kalan geleneksel ve tamamlayıcı tedavi yöntemlerinde ise ${ }^{69}$, doktor veya diş hekimi olma zorunluluğu bulunmadığı sonucuna ulaşılmaktadır.

67 Konuya ilişkin daha fazla bilgi için bkz. Hakeri, Tıbbi Müdahale, s. 18 vd.; Sarıyev, s. 67 vd.; Özer, s. 119 vd.

68 Geleneksel ve Tamamlayıcı Tıp Uygulamaları Yönetmeliği, her bir uygulama için, hangi sağlık personellerinin yetkili olduğu hususunda açık hükümlere yer vermiştir. Buna göre; ilgili yönetmelik uyarınca Akupunktur, Fitoterapi, Homeopati, Mezoterapi, Proloterapi ve Ozon Terapi, ilgili alanda eğitim ve sertifika almıs doktor veya sadece kendi alanıyla ilgili tedavide uygulamak üzere diş hekimi tarafından gerçekleştirilmelidir. Kupa uygulaması ve Osteopati ise, ilgili alanda eğitim ve sertifika almış doktor ve onun gözetiminde uygulama sertifikasına sahip yardımcı sağlık personeli veya kendi alanıyla sınırlı olmak üzere diş hekimi tarafından gerçekleştirilmelidir. Sülük uygulaması, Kayropraktik ve Refleksoloji ise, sadece ilgili alanda eğitim ve sertifika almış doktor ve uygulama sertifikasına sahip yardımcı sağlık personeli tarafından gerçekleştirilmelidir. Apiterapi ve Larva uygulaması ise, sadece ilgili alanda eğitim ve sertifika almış doktor tarafından gerçekleştirilmelidir. Hipnoz tedavisi ise, sadece ilgili alanda eğitim ve sertifika almış doktor veya kendi alanıyla ilgili tedavide uygulamak üzere diş hekimi tarafindan gerçekleştirilmelidir. Ayrıca hipnoz, sertifikalı doktor nezaretinde yapılmak şartıyla, klinik psikolog ve psikolojinin tıbbi uygulamaları yetki belgesine sahip psikolog tarafından da ifa edilebilir. Müzik terapi ise, sadece sertifikalı doktor veya onun nezaretinde sağlık meslek mensubu ile yine sertifikalı doktor gözetiminde en az lisans düzeyinde müzik eğitimi almış ve ilgili sertifika programını tamamlamış yardımcı kişi tarafından gerçekleştirilmelidir.

69 Aleksander Tekniği, Antroprofizik Tıp, Toksinlerden Arındırıcı Diyetler (Detox), Aromaterapi, Ayurveda, Bio-feedback, Biyoenerji, Biyo-kimya, Hidroterapi, Hirudoterapi, Kaplıca Tedavisi, Makrobiyotik, Masaj, Natüropati, Negatif İyon Tedavisi, Örüntü Tedavisi, Piramit Tedavisi, Psionik, Radyestezi, Radyonik, Reiki, 
İlgili geleneksel ve tamamlayıcı tedavi yöntemine ilişkin sertifikaya sahip doktorlar, uzman doktor olabileceği gibi, pratisyen doktor da olabilir ${ }^{70}$. Uygulama sertifikasına sahip diğer sağlık meslek mensupları ise, sadece sertifikalı doktor ve diş hekimi gözetimi ve denetimi altında bu uygulamalara katılabilirler. Böylece yönetmelikle tıp alanı dışında yer alan kişilerin bu uygulamaları gerçekleştirmelerinin önüne geçilmeye çalışılmıştır. Ancak uygulamayı gerçekleştirecek olan kişilerin sadece tıp alanında eğitim alması ve çalışması yeterli görülmemiş, ayrıca tıp veya diş hekimliği lisans eğitimi yanı sıra Sağlık Bakanlığı'nın yetkilendirdiği merkezlerden de bu hususta eğitim alarak sertifika edinmeleri şart koşulmuştur. Dolayısıyla doktor veya diş hekimi dişında yetkisiz kişilerce veya gerekli eğitim ve sertifika sahibi olmayan doktor veya diş hekimi tarafindan geleneksel ve tamamlayıcı tıp tedavisi uygulanması halinde, yapılan tıbbi müdahale hukuka aykırıdır ${ }^{71}$. Somut olayda, böyle bir hukuka aykırı fiil sonucunda belirli bir zarar da gerçekleşmişse uygulayıcının hukuki sorumluluğunun doğması kaçınılmazdır. Keza zarar olmayan yerde hukuki sorumluluk da bulunmaz. Nitekim fiilin hukuka aykırı olmasına ve hatta fiilin kusurlu bulunmasına rağmen bir zarar meydana gelmemişse, uygulayıcının hukuki sorumluluğundan bahsedilemez ${ }^{72}$.

Bunun dışında geleneksel ve tamamlayıcı tıp uygulamaları, hem uygulama üniteleri, hem de uygulama merkezleri bünyesinde gerçekleştirilebilir. Geleneksel ve Tamamlayıcı Tıp Uygulamaları Yönetmeliği m. 4/ g ve $\mathrm{h}$ bendinde, uygulama üniteleri, ilgili alanda sertifikası bulunan doktor veya diş hekimi sorumluluğundaki kamu ve özel hukuk tüzel kişiler ile gerçek kişilere ait sağlık kuruluşları olarak tanımlanırken; uygulama merkezleri, ilgili alanda sertifikası bulunan doktor veya diş hekimi sorumluluğunda geleneksel ve tamamlayıcı tıp uygulamalarını yapmak üzere Eğitim ve Araştırma Hastanesi, Tıp Fakültesi veya Diş Hekimliği Fakültesi Sağlık Uygulama ve Araştırma Merkezi bünyesinde kurulan merkezler olarak tanımlanmaktadır. Ayrıca Sağlık Bakanlığı'nın yetkilendirmesi neticesinde bahsi geçen uygulama merkezleri konuya ilişkin eğitimi de verebilmektedir.

Renk Tedavisi, Rolf Metodu, Tai Chi, Sesle Tedavi, Shiatsu, Şifacılık, Yoga/ Meditasyon Egzersizleri gibi.

70 Tokaç, Etik ve Hukuk, s. 157.

71 Konuya ilişkin ayrıntılı bilgi için bkz. Sarıyev, s. 86 vd.; Ayan, s. 5 vd.; Hakeri, Hakan: Tıp Hukuku, 19. Baskı, Seçkin Yayıncılık, Ankara 2020, s. 371 vd.; Şatır, Nejdet: Emsal Kararlar Işı̆̆ında Kamu ve Özel Hastanelerde Çalışan Hekimlerin Hukuki ve Cezai Sorumluluğu, 2. Bask1, Yekin Yayınevi, Ankara 2018, s. 20 vd.

72 Konuya ilişkin ayrıntılı bilgi için bkz. Eren, s. 520 vd.; Antalya, s. 449 vd. 
Böylece uygulama merkezleri, gerek eğitim ve uygulama, gerekse yönetmelikte belirtilen geleneksel ve tamamlayıcı tıbbi uygulamalarla ilgili bilimsel araştırmalar yapma hususunda teşvik edilmiştir ${ }^{73}$.

Sonuç olarak, doktor veya diş hekimi dişındaki kişilerce gerçekleştirilen geleneksel ve tamamlayıcı tıp uygulamalarının hukuka aykırı olduğu şüphesizdir. Ancak ilgili yönetmelikte belirtilen uygulamalar için sadece doktor veya diş hekimi olmak da yeterli görülmemektedir. Doktor olmakla birlikte, ilgili sertifikaya sahip olmayan doktor veya diş hekimleri tarafından gerçekleştirilen uygulamalar, sertifikalı diş hekimi tarafından kendi alanı dışında yapılan uygulamalar, sertifikalı doktor veya kendi alanıyla sınırlı olmak üzere sertifikalı diş hekimi gözetiminde olmayan sağlık meslek mensupları veya anılan sağlık personelleri dışında yer alan kişiler tarafından gerçekleştirilen uygulamalar hukuka aykırıdır ve bu kişilerin hukuki sorumlukları bulunmaktadır ${ }^{74}$.

\section{Aydınlatma ve Riza}

\section{a. Genel Olarak}

Hipokrat'ın doktorun hastayı aydınlatma gerekliliğine ilişkin önemli bir sözü bulunmaktadır: "Önce kelimeler, sonra ilaç, sonra neşter". Aydınlatma yükümlülüğünün gereği gibi yerine getirilmesi, sadece hastanın fiziksel ve zihinsel bütünlüğ̈̈ hakkında (hastanın kendi kaderini tayin hakkı uyarınca) karar vermesini sağlamakla kalmamaktadır ${ }^{75}$. Ayrıca hastada meydana gelebilecek psikolojik kaygının azalmasını ve hasta ile doktor arasında güven ilişkisinin oluşmasını sağlamaktadır (Salus aegroti suprema lex: "Das Wohl des Kranken ist das oberste Gesetz-Hastanın yararl en yüce yasa-

73 Ayrıca ilgili yönetmelik (m. 5/f. 2) uyarınca, Sağlık Bakanlığı tarafından multidisipliner uzmanlık alanlarına sahip, yönetmelikte belirlenen belirli nitelik ve nicelikte olan üyelerden "Geleneksel ve Tamamlayıcı Tip Uygulamaları Bilim Komisyonu” oluşturulur. $\mathrm{Bu}$ komisyon, geleneksel ve tamamlayıcı tıp uygulamalarının kapsamını belirlemek, uygulamalar sonucunda ortaya çıkabilecek yan etkilere ilişkin görüş vermek, uygulama yapılan ünite ve merkezlerde yer alması gereken asgari standart ve donanımları (tıbbi araç ve gereçler, personel ve fiziki standartlar gibi) belirlemek, ünite ve uygulama merkezlerinin kurulması için yapılan başvuruları değerlendirerek uygunluğu hususunda görüş bildirmek, geleneksel ve tamamlayıcı tıbbi uygulamalar ile ilgili bilimsel çalışmalar yapmak ve ihtiyaç halinde alt komisyonlar kurmakla görevlendirilmiştir.

74 Somut olayın şartlarına göre, haksız fiil veya sözleşme sorumluluğu söz konusudur. Konuya ilişkin ayrıntılı bilgi için bkz. Sarıyev, s. 86 vd.; Ayan, s. 5 vd.; Hakeri, Tıp, s. 371 vd.; Şatır, s. 20 vd.

75 Konuya ilişkin Yargıtay kararı için bkz. Y4HD., 07.03.1977 T., 1976/6297 E., 1977/ 12541 K., <https://www.kazancihukuk.com> E.T.: 05.04.2021. 
$\left.d \imath{ }^{\prime \prime}\right)^{76}$. Doktorun hastayı aydınlatma yükümlülüğüne ilişkin hükümler, ülkemizde Hasta Hakları Yönetmeliği'nde, Tabipler Birliği Meslek Etiği Kuralları'nda ve Tibbi Deontoloji Nizamnamesi ${ }^{77}$ 'nde yer almaktadır ${ }^{78}$.

Kural olarak doktorun her türlü tıbbi müdahalesi, her şeyden önce vücut dokunulmazlığının ihlali anlamına gelir ${ }^{79}$. Bu durumun hukuka uygun hale getirilmesi için, doktorun aydınlatma yükümlülüğünü yerine getirmesi, ardından hastanın da hiçbir baskı altında kalmadan ilgili tıbbi müdahaleye rıza göstermesi gerekmektedir. Doktor tarafindan hastaya veya bazı durumlarda yasal temsilcisine; tanı, hastaya uygulanabilecek tedavi alternatifleri, bu yöntemlerin riskleri, faydaları ve yan etkileri, tedavinin seyri ve tedavi uygulanmadığ 1 takdirde yaşanabilecek muhtemel sonuçlar hakkında bilgi verilmesi gereklidir. Zira hastaya veya yasal temsilciye bu konularda açık ve anlaşılabilir bir dille hem sözlü, hem de yazılı şekilde bilgi vermek, doktorun aydınlatma yükümlülüğünü oluşturmaktadır ${ }^{80}$.

76 Kim, Min-Joong: Aufklärungspflicht im Arztrecht - Eine zivilrechtliche Untersuchung über den Umfang und die Grenzen der ärztlichen Aufklärungspflicht mit rechtsvergleichenden Hinweisen, Göttingen 1989, s. 31; Müller, Sebastian/Raschke, Andreas: "Homöopathie durch Ärzte und die Einhaltung des medizinischen Standards", NJW, Heft 7, Y. 2013, s. 431.

$77 \quad 19.02 .1960$ tarihli 10436 sayılı Resmi Gazete'de yayınlanmıştır.

78 Hasta Hakları Yönetmeliği m. 31'e göre, "Rıza alınırken hastanın veya kanuni temsilcisinin tıbbi müdahalenin konusu ve sonuçları hakkında bilgilendirilip aydınlatılması esastır."; Tabipler Birliği Meslek Etiği Kuralları m. 26/f. 1'e göre, "hekim hastasını, hastanın sağllk durumu ve konulan tanı, önerilen tedavi yönteminin türü, başarı şansı ve

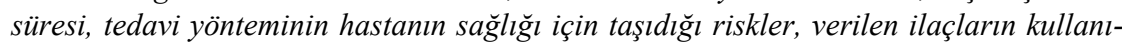
lışı ve olast yan etkileri, hastanın önerilen tedaviyi kabul etmemesi durumunda hastalığın yaratacă̆ sonuçlar, olası tedavi seçenekleri ve riskleri konularında aydınlatır. Yapılacak aydınlatma hastanın kültürel, toplumsal ve ruhsal durumuna özen gösteren bir uygunlukta olmalıdır. Bilgiler hasta tarafindan anlaşılabilecek biçimde verilmelidir. Hastanın dışında bilgilendirilecek kişileri, hasta kendisi belirler. Sağlıkla ilgili her türlü girişim, kişinin özgür ve aydınlatılmış onamı ile yapılabilir. Alınan onam, baskı, tehdit, eksik aydınlatma ya da kandırma yoluyla alındıysa geçersizdir." Benzer şekilde Tibbi Deontoloji Nizamnamesi m. 14/f. 2 uyarınca, "Tabip ve diş tabibi, hastasına ümit vererek teselli eder. Hastanın maneviyat üzerinde fena tesir yapmak suretiyle hastalı̆̆ın artması ihtimali bulunmadĭ̆ takdirde, teşhise göre alınması gereken tedbirlerin hastaya açıkça söylenmesi lazımdır."

79 Karş. BGH, NJW 1956, 1106 vd.; BGH NJW 1980, 1905 vd.; BGH NJW 1994, 127 vd., $<$ https:// beck-online.beck.de > E.T.: 13.01.2021.

80 Konuya ilişkin ayrıntılı bilgi için bkz. Deutsch, Erwin/Spickhoff, Andreas: Medizinrecht: Arztrecht, Arzneimittelrecht und Medizinprodukterecht und Transfusionsrecht, 6. neu bearbeitete und erweiterte Auflage, Springer Verlag, Berlin 2008, s. 162 vd.; Kern, Bernd Rüdiger/Laufs, Adolf: Die ärztliche Aufklärungspflicht, Springer Verlag, Berlin 1983, s. 11 vd.; Geiß, Karlmann/Greiner, Hans Peter: 
Aydınlatma yükümlülüğünün kapsamı, komplikasyonların sıklığı ve şiddetine, dolayısıyla tıbbi müdahalenin tehlikesinin derecesine göre belirlenmelidir ${ }^{81}$. Bununla birlikte aydınlatma yükümlülüğünün kapsamında, tıbbi müdahalenin aciliyeti de önemli rol oynamaktadır. Buna göre, tedavi yönteminin riskleri ve yan etkileri ne kadar öngörülemez ise veya tıbbi müdahalenin aciliyeti ne kadar az ise, doktorun aydınlatma yükümlülügü bir o kadar kapsamlı olmalıdır. Ayrıca kural olarak aydınlatma yükümlülüğü, tıbbi müdahaleyi gerçekleştirecek doktor tarafından gerçekleştirilmelidir. Eğer doktor, bu yükümlülüğünü başka bir doktora devretmek istiyor ise, bu yükümlülüğün diğer doktor tarafından gereği gibi ifa edildiğinden, ya hasta ile konuşarak, ya da tıbbi dosyalardaki hastanın yazılı beyanını kontrol ederek emin olmalıdır ${ }^{82}$.

Doktorun aydınlatma yükümlülüğünü yerine getirmesi, tıbbi müdahalenin hukuka uygun hale gelebilmesi noktasında tek başına yeterli değildir. Tıbbi müdahalenin hukuka uygun hale gelebilmesi, ayrıca hastanın gerekli aydınlatma sonucunda ilgili tıbbi müdahaleye rıza göstermesine bağlıdır ${ }^{83}$. Rizanın hukuka uygun hale gelebilmesi ise, hastanın tıbbi müdahalenin anlamı, seyri, kapsamı, başarı şansı, riskleri ve olası tedavi alternatifleri hakkında aydınlatıldıktan sonra, serbestçe iradesini göstermesine bağlıdır (Voluntas et salus aegroti: "Der Wille des Kranken ist das oberste GesetzHastanın iradesi en yüce yasadır") ${ }^{84}$. Hastanın rızasına ilişkin hükümler,

Arzthaftpflichtrecht, 7. überarbeitete Auflage, Verlag C. H. Beck, München 2014, Rn. 137 vd.; Özer, s. 121 vd.; Hakeri, Tıbbi Müdahale, s. 21 vd.; Özgül, s. 179 vd.; Zeytin, Zafer; "Hasta-Hekim İlişkisinde Hekimin Aydınlatma Yükümlülüğü”, Sağlık Hakkı Dergisi, Türk-Alman Tip Hukuku Sempozyumu Özel Sayısı, S. 3, Y. 2007, s. 165 vd.; Konuya ilişkin Yargitay kararı için bkz. Y13HD., 04.07.2018 T., 2016/25663 E., 2018/7615 K., <https://www.kazancihukuk.com> E.T.: 05.04.2021.

81 Konuya ilişkin ayrıntılı bilgi için bkz. Jansen, Christoph: "Behandlungs- und Aufklärungsfehlerhaftung bei der Wahl eines nicht standartgemäßen Behandlungskonzept", MedR, S. 38, Y. 2020, s. 379 vd.; Kern/Laufs, s. 23 vd.; Deutsch/Spickhoff, s. $167 \mathrm{vd}$.

82 Helbron, Hanja: Entwicklungen und Fehlentwicklungen im Arzthaftungsrecht, Herbert Utz Verlag, München 2001, s. 86 vd.; Geiß/Greiner, Rn. 137; BGH NJW 1963, 393 vd.; BGH, NJW, 2011, s. 1089 vd.; BGH, NJW, 2017, s. 2685 vd., <https:// beckonline.beck.de > E.T.: 04.02.2021.

83 Konuya ilişkin ayrıntılı bilgi için bkz. Akyıldız, s. 206 vd.; Hakeri, Tıbbi Müdahale, s. 21 vd.; Sarıyev, 102 vd.; Özgül, s. 234 vd.; İlgili Yargıtay kararı için bkz. Y13HD., 15.09.2014 T., 2013/26330 E., 2014/27050 K., Y13HD., 18.09.2008 T., 2008/4519 E., 2008/10750 K., <https://www.kazancihukuk.com> E.T.: 05.04.2021.

84 Engisch, Karl: "Heilengriff und ärztliche Aufklärungspflicht", Die ärztliche Aufklärungspflicht aus rechtlicher und ärztlicher Sicht (Hrsg.: Engisch, Karl/ Hallermann, Wilhelm), Carl Heymann Verlag, Köln 1970, s. 11. 
ülkemizde Tababet ve Şuabatı San'atlarının Tarzı İcrasına Dair Kanunu'nda, Hasta Hakları Yönetmeliği'nde, Türk Tabipler Birliği Meslek Etiği Kuralları'nda, Disiplin Yönetmeliği'nde ${ }^{85}$ ve Biyotıp Sözleşmesi'nde yer almaktadir $^{86}$.

\section{b. Geleneksel ve Tamamlayıcı Tip Uygulamalarinda Aydınlatma ve Riza}

Konvansiyonel tıp eğitimi almış bir doktorun hastayı, ayrıca geleneksel ve tamamlayıcı tıp uygulamaları hakkında aydınlatması gerekliliği, doktrinde tartışmalıdır. Doktrinde yer alan bir görüşe göre; doktor hastayı, (akupunktur, fitoterapi, homeopati gibi) en azından belirli bir seviyede tanınmış ve tıp çevrelerince kabul görmüş geleneksel ve tamamlayıcı tedavi yöntemleri hususunda bilgilendirmelidir. Bu görüşe göre ${ }^{87}$, konvansiyonel tıbbın yanı sıra veya konvansiyonel tıp yerine hastalığın tedavisinde olumlu sonuçları olabilecek, belirli düzeyde tanınmış ve kabul görmüş geleneksel ve tamamlayıcı tedavi yöntemleri hakkında hasta aydınlatılmalıdır. Bu görüş-

$85 \quad 28.04 .2004$ tarihli 25446 sayılı Resmi Gazete'de yayınlanmıştır.

86 Türk hukuk sisteminde hastanın rızasına ilişkin hükümler, ülkemizde Tababet ve Şuabatı San'atlarının Tarzı İcrasına Dair Kanunu'nda, Hasta Hakları Yönetmeliği'nde, Türk Tabipler Birliği Meslek Etiği Kuralları'nda, Disiplin Yönetmeliği'nde ve Biyotıp Sözleşmesi'nde yer almaktadır: 1219 sayılı Tababet ve Şuabatı San'atlarının Tarzı İcrasına Dair Kanunu m. 70'e göre, “Tabipler, diş tabipleri ve dişçiler yapacakları her nevi ameliye için hastanın, hasta küçük veya tahtı hacirde ise veli veya vasisinin evvelemirde muvafakatını alırlar. Büyük ameliyei cerrahiyeler için bu muvafakatin tahriri olması lazımdır." Hasta Hakları Yönetmeliği m. 22'e göre, “Kanunda gösterilen istisnalar hariç olmak üzere, kimse, rızası olmaksızın ve verdiği rızaya uygun olmayan bir şekilde tıbbi ameliyeye tabi tutulamaz. Bir suç işlediği veya buna iştirak ettiği şüphesi altında bulunan kişinin işlediği suçun muhtemel delillerinin, kendisinin veya mağdurun vücudunda olduğu düşünülen hallerde; bu delillerin ortaya çıkarılması için sanığın veya mağdurun tıbbi ameliyeye tabi tutulmasl, hakimin kararına bağlıdır. Gecikmesinde sakınca bulunan hallerde bu ameliye, cumhuriyet savcısının talebi üzerine yapılabilir." Biyotıp sözleşmesi m. 5'e göre, "Sağlık alanında herhangi bir girişim, ilgili kişinin bu girişime özgürce ve bilgilendirilmiş bir şekilde rıa(onam) vermesinden sonra yapılabilir. Bu kişiye, önceden, girişimin amacı ve niteliği ile sonuçları ve tehlikeleri hakkında uygun bilgiler verilecektir. İlgili kişi, verdiği onamı her zaman, serbestçe geri çekebilir." Türk Tabipler Birliği Meslek Etiği Kuralları m. 26/f. 2 ve Disiplin Yönetmeliği m. 4'te de konuya ilişkin benzer hükümler yer almaktadır.

87 Wiegand, Wolfgang: "Die Aufklärungspflicht und die Folgen ihrer Verletzung", Handbuch des Arztrechts (Hrsg.: Heinrich Honsell), Zürich 1994, s. 141; Benzer görüş için bkz. Tokaç, Etik ve Hukuk, s. 159; Söğüt, İpek Sevda: "Geleneksel ve Tamamlayıcı Tıp Uygulamalarında Aydınlatılmış Onam Sorunu”, İstanbul Kültür Üniversitesi Hukuk Fakültesi Dergisi, C. 2, S. 16, Y. 2017, s. 642 vd.; Sarıyev, s. 95 vd. 
teki kilit nokta, geleneksel ve tamamlayıcı tıbbi yöntem hakkında doktor, ister eğitim ve sertifika almış, ister almamış olsun, eğer hastalığın tedavisinde tıp çevrelerince en azından belirli düzeyde tanınmış geleneksel ve tamamlayıcı tıbbi yöntem bulunmaktaysa, hastayı bu yöntem hakkında mutlaka bilgilendirmelidir. Bir diğer ifadeyle, doktorun geleneksel ve tamamlayıc1 tıp hususunda hastayı aydınlatma yükümlülüğünün doğması için, hastalığın tedavisinde öngörülen yöntemin belirli düzeyde tanınmış olması şarttır. Eğer böyle bir geleneksel ve tamamlayıcı tedavi yöntemi bulunmamaktaysa, doktorun hastayı aydınlatma yükümlülüğü yoktur.

Bizim de katıldığımız diğer bir görüşe göre ise ${ }^{88}$, konvansiyonel tıp doktorlarının geleneksel ve tamamlayıcı tedavi yöntemleri hakkında hastaya bilgi verme zorunluluğu bulunmamaktadır. Zira doktorların aydınlatma yükümlülüğü zaten kapsamlı olmak zorundadır. Ayrıca doktora geleneksel ve tamamlayıcı tıbbi uygulamalar hakkında hastayı aydınlatma yükümlülüğü yüklenecek olursa, bu zaten kapsamlı olması gereken aydınlatma yükümlülüğünün kapsamını iyice genişletecek ve doktora taşıyamayacağı kadar yükler yüklenmiş olacaktır. Bu görüşe göre, doktorun geleneksel ve tamamlayıc1 tıp uygulamaları hakkında hastayı bilgilendirme zorunluluğu olup olmadığının belirlenmesinde belirleyici faktör, geleneksel ve tamamlayıcı tedavi hakkındaki aydınlatmanın, hastayı tedavi eden doktor için uzmanlık bilgisini temsil edip etmediğidir. Ancak şu unutulmamalıdır ki; uzmanlık alanıyla ilişkili olan ve tamamlayıcı tıp eğitimi almış her doktorun hastalarına mutlaka geleneksel ve tamamlayıcı tıp tedavisini uygulayacağı anlamına gelmemelidir. Zira bu sadece, doktorun hastalığın tedavisi için kabul edilmiş geleneksel ve tamamlayıcı tedavinin olduğunu bildiği anlamına gelir. Eğer tedavi, doktorun aldığı eğitimin bir parçası değilse, buna karşılık gelen bir aydınlatma doktordan beklenmemelidir. Konvansiyonel tıp eğitimi almış bir doktor, ayrıca geleneksel ve tamamlayıcı tıp konusunda eğitim almış ve

88 Laufs, Adolf/Katzenmeier, Christian/Lipp, Volker: Arztrecht, 8. völlig neu bearbeitete Auflage, C. H. Beck, München 2021, Rn. 34-35; Fink, Claudia: Die Aufklärungspflicht von Medizinalpersonen (Arzt, Zahnarzt, Tierarzt, Apotheker), Stämpfli Verlag, Bern 2008, s. 141 vd.; Kim, s. 66 vd.; Müller/Raschke, s. 432; Shenbao, Liang: Einwilligung in medizinische Behandlungen, eine rechtsvergleichende Analyse nach schweizerischem und chinesischem Privatrecht, Arbeiten aus dem Juristischen Seminar der Universität Freiburg Schweiz (Hrsg.: Peter Gauch, Schulthess), Zürich 2018, Rn. 455 vd.; Roggo, Antoine: Aufklärung des Patienten-eine ärztliche Informationspflicht, 1. Auflage, Stämpfli Verlag, Bern 2002, s. 92 vd.; Schumacher, Arzthaftungsrecht, s. 790 vd.; Schelling, Philip/Erlinger, Rainer: "Die Aufklärung über Behandlungsalternativen”, MedR, Heft 6, Y. 2003, s. 331 vd.; Deutsch/Spickhoff, s. 140 vd.; Hakeri, Geleneksel Tip, s. 35; Özgül, s. 195 vd. 
yeterlilik sertifikasına sahipse, eğitim ve yeterlilik belgesi kapsamında yer alan bir tedavi hasta için uygun bir tedavi yöntemini içeriyorsa, ancak bu takdirde doktordan hastayı bu konuda aydınlatması beklenmelidir. Özellikle konvansiyonel tıpta tedavisi (en azından henüz) bulunmayan ciddi hastalıklar söz konusu olduğunda veya hastanın konvansiyonel tıbba rağmen tedavisiz kaldığı düşünülen durumlarda, bu hususta sertifikalı doktorların hastalarını kendi uzmanlık alanlarında geleneksel ve tamamlayıcı tedaviyi kullanma olasılığı hakkında bilgilendirmeleri oldukça makul görünmektedir.

Sonuç olarak kanaatimizce, geleneksel ve tamamlayıcı tedavi yöntemleri hakkında her doktorun hastayı aydınlatma yükümlülüğü olduğu söylenemez. Bir diğer ifadeyle, doktor, uzmanlık alanı ile ilgili geleneksel ve tamamlayıcı tıbbi yöntemler hakkında bilgi sahibi ise, ancak bu hususta eğitimi ve yeterlilik sertifikası bulunmuyorsa, doktordan hastayı geleneksel ve tamamlayıcı tıbbi yöntemler hakkında bilgilendirmesi beklenmemelidir. Ancak doktorun hastayı konvansiyonel tıbbin yanı sıra, geleneksel ve tamamlayıcı tedavi yöntemleri hakkında da aydınlatmasında herhangi bir sakınca yoktur. Zira doktor sadece yerleşik tıp hakkında bilgiye sahip olmak zorunda değildir, aynı zamanda yabancı ve keşfedilmemiş bölge alanındaki tedavi yöntemlerine ilişkin de bilgi sahibi olabilir. Aslında bu donanım, tıp biliminin gelişmesi ve ilerlemesi açısından gereklidir. Ĕger doktor hastalığın tedavisi kapsamında yer alan ve bu yönde tedavi sunan bir geleneksel ve tamamlayıcı tıbbi yönteme ilişkin yeterlilik sertifikası almışsa, işte bu durumda hastanın geleneksel ve tamamlayıcı tedavi yöntemleri hakkında aydınlatılması doktorun yükümlülüğüdür. Dolayısıyla aşağıda konuya ilişkin yapılan açıklamalar, geleneksel ve tamamlayıcı tıbbi yönteme ilişkin eğitim ve yeterlilik sertifikası almış doktorların aydınlatma yükümlülügüne ilişkindir.

Doktorun hastayı aydınlatma yükümlülüğünün kapsamı, özellikle geleneksel ve tamamlayıcı tıp uygulamalarında önem arz etmektedir. Zira bir doktorun uygulayacağ 1 tıbbi yöntem ne kadar tanınmış ve yerleşmiş bir uygulamaysa, o oranda doktorun hastayı aydınlatma yükümlülügü daha az olacaktır. Ancak bir doktorun uygulayacağı tıbbi yöntem ne kadar yeni veya bilimsel olarak tartışmalı ise, doktorun hastayı aydınlatma yükümlülüğü ve özen yükümlülüğünün kapsamı genişleyecektir ${ }^{89}$. Böylece geleneksel ve

89 Damm, Reinhard: "Medizintechnik und Arzthaftungsrecht: Behandlungsfehler und Aufklärungspflicht bei medizintechtechnischen Behandlungsalternativen", NJW, Heft 12, Y. 1989, s. 737 vd.; Müller/Raschke, s. 431 vd.; Geiß/Greiner, Rn. 137; Jansen, s. 379 vd.; Schubarth, s. 1090; Schumacher, Arzthaftungsrecht, s. 790 vd.; Vogeler, 
tamamlayıcı tıp uygulamalarında çoğu zaman yan etkiler hakkında yeterli bilginin olmaması ve uygulama sonucunda oluşabilecek komplikasyonların belirsizliği sebebiyle, kural olarak geleneksel ve tamamlayıcı tıp uygulamalarından herhangi birini seçen sertifikalı doktorun, konvansiyonel tıp uygulamalarına nazaran hastayı aydınlatma yükümlülüğü daha yoğun olarak karşımıza çıkmaktadır. Ayrıca tıbbi müdahalenin aciliyeti de aydınlatma yükümlülüğünün kapsamını etkilemektedir. Buna göre, bağışıklığı güçlendirmek ve sağlık halini sürdürmek amaciyla uygulanan geleneksel ve tamamlayıcı tedavi yönteminde aciliyet unsuru olmadığı için, doktorun aydınlatma yükümlülüğü daha kapsamlı olmalıdır ${ }^{90}$. Aciliyet unsuru, hayatın devamı için gerekli tıbbi müdahalelerde söz konusu olması cihetiyle, aslında geleneksel ve tamamlayıcı tıbbi uygulamalar için söz konusu olmamalıdır. Bir diğer ifadeyle, acil tıbbi müdahale gereken durumlarda, standart tedavinin uygulanması, dolayısıyla konvansiyonel tıbbın tercih edilmesi gerekmektedir ${ }^{91}$. Ancak söz konusu durum, acil vakanın tedavisi için konvansiyonel tıpta standart bir tedavinin öngörülüyor olması halinde geçerlidir. Eğer somut olayda, acil vakaya ilişkin olarak konvansiyonel tıptaki standart tedavinin sonuç vermeyeceği aşikar ise veya herhangi bir standart tedavi bulunmuyorsa, Tibbi Deontoloji Nizamnamesi m. 11 doğrultusunda ${ }^{92}$, hasta

Marcus: "Die Haftung des Arztes bei der Anwendung neuartiger und umstrittener Heilmethoden nach der neuen Rechtsprechung des BGH", MedR, S. 26, Y. 2008, s. 697 vd.; Hakeri, Geleneksel Tip, s. 33 vd.; Söğ̈̈t, s. 642 vd.; Bu yönde Alman Federal Yüksek Mahkemesi'nin "Robodoc" kararına göre, herkes tarafından tanınmış standart tedavi yöntemlerini kullanmak yerine, yeni ve henüz yaratacağı riskler kesin olarak açıklanmamış tedavi yöntemlerinin kullanılması halinde, ilk derece mahkemeleri tarafindan "bilinmeyen risklerin şu anda göz ardı edilemeyeceğine dair" bir açıklama gereklidir. BGH, yeni prosedürlerin uygulanmasının tıbbi ilerleme için gerekli olduğunu düşünür. Ancak bu, doktoru, yeni yöntemin ileriye dönük avantajlarını ve bilinmeyen tehlikeleri dikkate alarak bilgi sağlamaktan ve hastayı dikkatli bir şekilde değerlendirmekten kurtarmaz. BGH, ne ilacın onaylanmaması hakkında bilgi verilmemesi, ne de bilinmeyen risklerin tehlikelerinin açıklığa kavuşturulmaması nedeniyle, aydınlatma yükümlülüğünün doktor tarafından ihlal edildiğine karar veren İstinaf Mahkemesi kararını onamıştır. İlgili karar için bkz. BGH, NJW, 2006, 2477 vd. Benzer Alman Federal Mahkemesi kararları için bkz. BGH, NJW, 2007, s. 2767 vd.; BGH, NJW, 2007, s. 2774 vd.; BGH, NJW, 2017, s. 2685 vd., <https://beck-online.beck.de > E.T.: 21.01.2021.

90 Söğüt, s. 642; Özgül, s. 227 vd.

91 Keza Geleneksel ve Tamamlayıcı Tıp Uygulamaları Yönetmeliği m. 8/b. 4'e göre, "geleneksel ve tamamlayıcı tıbbi uygulama, hastalığın standart tedavisinin yerine geçecek ve devam eden tedaviyi aksatacak şekilde yapılamaz. Bu husus bireylere açık bir şekilde anlatılır ve onaylanmış rıza formunda belirtilir."

92 "Klâsik metotların bir hastaya fayda vermeyeceği klinik veya laboratuvar muayeneleri neticesinde sabit olduğu takdirde daha önce, mutat tecrübe hayvanlart üzerinde kâfi 
için faydalı olabileceğine veya en azından herhangi bir zarar doğurmayacağına kanaat getirilen geleneksel ve tamamlayıcı tedavi yöntemi uygulanabilir ${ }^{93}$.

Her durumda doktor, hastaya yöntemin tıbbi standarttan saptığını ve söz konusu yöntemin etkinliği ve faydalarının istatistiksel olarak belirsiz veya tartışmalı olduğunu açıķ̧a bildirmelidir. Aynı zamanda doktor, bu yöntemi neden seçtiğini ve ilgili tedavinin olası avantaj ve dezavantajlarını da hastaya açık bir şekilde anlatmalıdır. Hasta bilinçli olarak sadece geleneksel ve tamamlayıcı tedavi yöntemi sunan bir doktora başvurduğunda dahi bu durum değişmez. Aksine hasta konvansiyonel tıp doktoruna başvurmuşsa, bu durumda doktor, hastayı ayrica geleneksel ve tamamlayıcı tedavi yöntemleri hakkında bilgilendirmek zorunda değildir ${ }^{94}$.

Doktor, geleneksel ve tamamlayıcı tıp yönteminin niteliğini, mahiyetini, anlamını, özellikle başarı şansını ve risklerini hastaya konvansiyonel tıp perspektifinden anlaşılır bir dille açıklamakla yükümlüdür. Hastalığın tedavisinde geleneksel ve tamamlayıcı tedavi yönteminin kullanılmak istenmesi halinde doktor, hastayı mutlaka aynı hastalık için konvansiyonel tıpta öngörülen standart tedavi yöntemi hakkında da aydınlatmalıdır ${ }^{95}$. Aynı şsekilde

derecede denenmek suretiyle faydalı tesirleri anlaşılmış olan bir tedavi usulünün tatbiki caizdir. Şu kadar ki, bu tedavinin tatbik edilebilmesi için, hastaya faydalı olacağının ve muvaffakiyet elde edilmemesi halinde ise mutat tedavi usullerinden daha elverişsiz bir netice alınmayacağının muhtemel bulunması şarttır. Evvelce tecrübe edilmiş olmamakla beraber, zarar vermesine ihtimal bulunmayan ve hastayı kurtarması kati görülen bir müdahale yapılabilir."

93 Benzer görüş için bkz. Özgül, s. 227 vd.

94 Laufs/Katzenmeier/Lipp, Rn. 36; Damm, s. 737 vd.; Müller/Raschke, s. 432; Geiß/Greiner, Rn. 137; Jansen, s. 379 vd.; Schubarth, s. 1090; Schumacher, Arzthaftungsrecht, s. 790 vd.; Vogeler, s. 697 vd.

95 Alman Federal Yüksek Mahkeme'nin kararına konu olan bir olaya göre, rahim ağzı kanserine yakalanan bir kişi, bir üniversitenin kadın kliniğinde bir yıl tedavi görmüştür. Klinik doktoru hastaya bilimsel olarak kanıtlanmış bir tedavi yöntemi uygulamak yerine, şifalı bitki özleri, sıcak su oturma banyoları ve özel bir diyet ile tedavi etmiştir. Bu tedavi sonucunda hastada geçici bir iyileşme sağlanmış; ancak kanserin tedavi edilmemesi neticesinde kanserden kaynaklanan komplikasyonlar sonucunda hasta ölmüştür. Yerel Ceza Mahkemesi, doktoru sadece taksirli adam yaralama suçundan para cezasına hükmetmiştir. Ancak temyiz edilen yerel ceza mahkeme kararı, Federal Yüksek Mahkeme tarafindan bozulmuştur. Zira Federal Yüksek Mahkemeye göre, doktor güvenilir tıbbi bir kontrol gerçekleştirmemiştir. Özellikle kanser hastasını hemen klinik tedaviye sevk etmesi gerekirken, doktor sadece göz teşhisine güvenerek, hastayı ayakta tedavi etmeye çalışmıştır. Oysa kanser hastalıkları sadece cerrahi veya radyoterapi yoluyla tedavi edilerek optimal iyileşme başarısı elde edilmelidir. Ayrıca doktorun kanser hastalığ 1 tedavisinde yeterli tıbbi deneyime sahip olmadığı tespit edilmiştir. Sanık, biyolojik 
ciddi bir hastalığı olmasına rağmen, hastanın ısrarla geleneksel ve tamamlayıcı tedavi yöntemini istemesi halinde doktor, mutlaka konvansiyonel tıp standardının gerekliliğine işaret etmelidir. Toplumun bazı kesimlerinin geleneksel ve tamamlayıc1 tedavi yöntemlerinin, konvansiyonel tıbba göre daha az riskli olduğuna inandığı düşünüldüğünde, bu yaklaşım daha doğrudur $^{96}$. Konuya ilişkin olarak Geleneksel ve Tamamlayıcı Uygulamaları Yönetmeliği'ne göre (m. 8 uyarınca), "uygulamalar hastalığın standart tedavisinin yerine geçecek ve devam eden tedaviyi aksatacak şekilde yapılamaz. Bu husus bireylere açık bir şekilde anlatılır ve onaylanmış, rıza formunda belirtilir". Böylece ilgili yönetmelik, geleneksel ve tamamlayıcı tedavi yönteminin konvansiyonel tıbbın öngördüğü standart tedavinin yerine kullanılmaması ve asıl tedaviye engel olmaması gerektiğini vurgulamış ve

şifa yöntemlerinin hayranıdır. Mahkemeye göre, sözde konvansiyonel tıp ile çelişen bir doktor bile deneyimlerini göz ardı etmemelidir. Bu özellikle hayatı tehdit eden hastalıklar söz konusu olduğunda geçerlidir. Doktor böyle bir durumda kendi tedavi yönteminin yetersiz veya başarısız olduğunu fark etmesi gerektiğinde, hastalığın tedavisi için yaygın olarak kullanılan ve kanıtlanmış başka bir yöntem mümkünse ya bunu kullanmalı ya da tedaviyi sonlandırmalıdır. Doktorun hastayı derhal klinik tedaviye yönlendirmesi gerekirken kendi seçtiği etkisiz tedaviye devam etmesi sebebiyle ceza mahkemesinin kararı bozulmalıdır. Zira Yerel Ceza Mahkemesi, hastanın ölümünün doktorun tedavi başar1sızlığından kaynaklandığı kanaatine varamamıştır. Ayrıca mahkeme hastanın yaşam süresinin uygun tedavi ile uzatılabileceğini de öngörememiştir. Rahim kanseri, radyasyon veya ameliyat yoluyla iyileşme şansının özellikle yüksek olduğu bir kanser türüdür. Burada kanserli tümördeki büyüme tamamıla doktorun kusurundan kaynaklanmaktadır. Muhtemelen daha sonra kanser büyümelerinin başka yerlerde oluşmuş olacağ 1 gerçeği, sağlığa verilen zararı ortadan kaldırmaz. İlgili karara (Unterlassung einer Krebsbehandlung nach Regeln der Schulmedizin) ilişkin bilgi için bkz. BGH, NJW, 1960, s. 2253 vd.; Benzer Alman Federal Yüksek Mahkeme kararları için bkz. BGH, NJW, 2007, 2774 vd.; BGH, NJW, 2007, 2771 vd.; BGH, NJW, 2007, s. 2767 vd., $<$ https://beck-online.beck.de> E.T.: 13.01.2021.

96 Doktorun hastaya geleneksel ve tamamlayıcı tıbbi tedavinin sağlık sigortası tarafindan karşılanmayabileceğini belirtmesi gerekip gerekmediği sorusu gündeme gelmektedir. Bu husus, doktorun aydınlatma yükümlülüğünün kapsamı ile yakından ilgilidir. Alman Federal Mahkemesi, doktorun hastayı sağlık sigortasının tüm masrafları karşılayamayacağı veya geri ödeyemeyeceği konusunda bilgilendirmesini isteme eğilimindedir. Ekonomik aydınlatmanın kapsamı tartışmalı olmakla birlikte, doktor, sağlık sigortasının tedavi masraflarını karşılamayacağının kolayca anlaşılabilir olduğu durumlarda, hastayı bu durum hakkında aydınlatmakla yükümlüdür. Geleneksel ve tamamlayıcı tedavi yöntemi, sağlık sigortası tarafından karşılanmıyorsa ve doktor bunu kolaylıkla fark edebiliyorsa, tedaviden önce hastayı bu konuda aydınlatmalıdır. Doktor, bu yükümlülüğünü ihlal ederse, tedavi masraflarını hastadan talep edemez. Konvansiyonel tıbbın aksine, geleneksel ve tamamlayıcı tedavinin hastanın farazi iradesine göre kullanılmasına sadece hastanın daha önce geleneksel ve tamamlayıcı tedavi görmüş olması gibi güvenilir göstergeler var ise izin verilebilir, Müller/Raschke, s. 432. 
bu hususa ilişkin olarak doktora, hastayı aydınlatma yükümlülüğü yüklemiştir. Ayrıca ilgili yönetmelik m. 10/5 uyarınca, Hasta Hakları Yönetmeliği'ne atıf yapılarak, bilgilendirme ve rıza formunun Hasta Hakları Yönetmeliği’nin ilgili hükümleri ${ }^{97}$ uyarınca hazırlanıp, hastaya verilmesini ve bu doğrultuda hastadan yazılı olarak rıza alınması gerektiğini hükme bağlamiştır.

Doktor, hastaya geleneksel ve tamamlayıcı tedavi yöntemlerinin kendine özgü risklerini açıklamalıdır ve hastayı bilinmeyen risklerinin şu anda göz ardı edilemeyeceği konusunda bilgilendirmelidir. Hasta, bilinen risklerle konvansiyonel tıbbi yönteme göre mi, yoksa geleneksel ve tamamlayıcı tıbbi yönteme göre mi tedavi edilmek isteyip istemediğine, olası faydalar ve her açıdan henüz bilinmeyen tehlikeler özel olarak dikkate alınarak, kendi kendine karar verebilecek bir konuma getirilmelidir. Zira hasta, kendi kaderini tayin hakkından mahrum bırakılmamalıdır ${ }^{98}$. Bilinmeyen riskler hakkında ayrıntılı bilgi verilmesi mümkün olmadığından, doktor tarafından genel ama net bir bilgilendirme yeterlidir. Doktor, özellikle geleneksel ve tamamlayıcı yöntemin konvansiyonel yöntemden daha yüksek bir riskle ilişkilendirildiği

97 Hasta Hakları Yönetmeliği m. 15 uyarınca bildirmenin kapsamı şu şekildedir: Doktor tarafindan hastaya; hastalığın muhtemel sebepleri ve nasıl seyredeceği, tıbbi müdahalenin kim tarafından nerede, ne şekilde ve nasıl yapılacağı ile tahmini süresi, diğer tanı ve tedavi seçenekleri ve bu seçeneklerin getireceği fayda ve riskler ile hastanın sağlığı üzerindeki muhtemel etkileri, muhtemel komplikasyonları, reddetme durumunda ortaya çıkabilecek muhtemel fayda ve riskleri, kullanılacak ilaçların önemli özellikleri, sağlığı için kritik olan yaşam tarzı önerileri, gerektiğinde aynı konuda tıbbî yardıma nasıl ulaşabileceği hususlarında bilgi verilir. Aynı yönetmeliğin 18. maddesinde ise, bilgilendirmenin nasıl gerçekleştirilmesi gerektiğine ilişkin husus açıklanmıştır. Buna göre; bilgi, mümkün olduğunca sade şekilde, tereddüt ve şüpheye yer verilmeden, hastanın sosyal ve kültürel düzeyine uygun olarak anlayabileceği şekilde verilir. Hasta, tıbbi müdahaleyi gerçekleştirecek sağlık meslek mensubu tarafından tıbbi müdahale konusunda sözlü olarak bilgilendirilir. Bilgilendirme ve tıbbi müdahaleyi yapacak sağlik meslek mensubunun farklı olmasını zorunlu kılan durumlarda, bu duruma ilişkin hastaya açıklama yapılmak suretiyle bilgilendirme yeterliliğine sahip başka bir sağlık meslek mensubu tarafından bilgilendirme yapılabilir. Hastanın kendisinin bilgilendirilmesi esastır. Hastanın kendisi yerine bir başkasının bilgilendirilmesini talep etmesi halinde, bu talep kişinin imzası ile yazılı olarak kayıt altına alınmak kaydıyla sadece bilgilendirilmesi istenilen kişilere bilgi verilir. Hasta, aynı şikayeti ile ilgili olarak bir başka hekimden de sağlık durumu hakkında ikinci bir görüş almayı talep edebilir. Acil durumlar dışında, bilgilendirme hastaya makul süre tanınarak yapılır. Bilgilendirme uygun ortamda ve hastanın mahremiyeti korunarak yapılır. Hastanın talebi halinde yapılacak işlemin bedeline ilişkin bilgiler sağlik hizmet sunucusunun ilgili birimleri tarafindan verilir.

98 Konuya ilişkin Yargıtay kararı için bkz. Y4HD., 07.03.1977 T., 1976/6297 E., 1977/ $12541 \mathrm{~K} .,<$ https://www.kazancihukuk.com> E.T.: 05.04.2021. 
durumlarda bunu belirtmelidir. Çeşitli tedavi alternatifleri hakkında bilgi vermenin amacı, hastanın bir veya diğer yöntem için karar vermesini kolaylaştırmaktır. Ancak bu, hastanın çeşitli yöntemlerin tehlikelerinden haberdar edilmesini gerektirir. $\mathrm{Bu}$ nedenle hasta, tedavinin nasıl yapılmas1 gerektiğine, hangi zamanda, hangi noktada hangi riski kabul etmek istediğine bağımsız olarak karar verebilmesi için gerekli, eksiksiz tıbbi bilgilendirme ile etkinleştirilmelidir. Özetle, doktorun tedavi seçimi ile aydınlatma yükümlülüğü arasında sıkı bir ilişki olduğu söylenebilir. Dolayısıyla doktor, yerleşik ve bilimsel olarak tanınan tedavi yöntemlerinden ne kadar saparsa veya yeni tıbbi yöntemleri hastada denemek isterse, o kadar aydınlatma yükümlülüğünün kapsamı genişlemektedir. Amaçlanan tedavi türü yalnızca bilimsel olarak tartışmalı değil, aynı zamanda standart iyileştirme yöntemleriyle de çelişiyorsa, hasta için daha kapsamlı miktarda bilgi mutlak surette gereklidir ve bu bilgilendirme ispat kolaylığı açısından yazılı olmalıdır ${ }^{99}$.

Geleneksel ve tamamlayıcı tedavi yöntemini kullanan doktor, hastaya konvansiyonel tıp yerine, hastalığın tedavisinde bu yöntemi neden tercih ettiğini mutlaka bilimsel kanıtlarla göstermelidir. Eğer geleneksel ve tamamlayıcı tedavi yöntemi konvansiyonel tıp tarafından açıkça reddedilmekteyse, bu durumda da doktorun bunu hastaya bildirme zorunluluğu bulunmaktadır. Bu bağlamda doktor, konvansiyonel tıbbın teşhis yöntemlerini göz ardı etmemeli, özellikle uygulanan geleneksel ve tamamlayıcı tıbbi yöntemin teşhislerinin doğruluğuna ilişkin yeterli ampirik kanıt bulunmamaktaysa, bunu hastaya bildirmelidir. Kendisini geleneksel ve tamamlayıcı tıbbi yönteme emanet eden hasta, bu tedavinin tüm detaylarını bilmelidir. Hastaya, doktor tarafından bilinçli ve yanlış iyileşme umutlarının sunulmasının, rızayı

99 Laufs/Katzenmeier/Lipp, Rn. 36; Schumacher, Arzthaftungsrecht, s. 789 vd.; Konuya ilişkin "Heilversuch" isimli kararında Alman Federal Yüksek Mahkemesi, Karlsruhe Bölge Yüksek Mahkemesi’nin kararını bozmuştur. Karlsruhe Bölge Yüksek Mahkemesi, henüz onaylanmamış bir ilacın uygulamak isteyen sanık doktorun hastanın bu yönde farazi iradesi olduğu için illiyet bağının olmadığ 1 ve bu yüzden sorumluluğunun söz konusu olmadığına karar vermiştir. Oysa Alman Federal Yüksek Mahkemesi'ne göre, henüz onaylanmamış bir ilacın uygulanması için davacının farazi bir rızasının varsayılması hukuka aykırıdır. Zira böyle bir durumda, doktorun sorumluluğunun ortadan kalkabilmesi için farazi rızanın varlığı yeterli değildir, BGH, NJW, 2007, s. $2767 \mathrm{vd}$. <https:// beck-online.beck.de > E.T.: 20.01.2021; Konuya ilişkin benzer Alman Federal Yüksek Mahkemesi'nin “Racz-Methode” isimli kararına göre, doktorun bilimsel olarak tartışmalı ağrı tedavisinin yeniliğine işaret etmemiş olması, ancak sadece başarısızlık riskine işaret etmiş olması doktorun aydınlatma yükümlülüğünün ihlalidir, BGH, NJW, 2007, 2774 vd. <https:// beck-online.beck.de $\geq$ E.T.: 20.01.2021; Bodenburg, Reinhard: "Alternative Medizin im Spannungsfeld von Heilungschancen und ärztlichem Risiko", NJOZ, Heft 33, Y. 2009, s. 2825 vd. 
ve dolayısıyla tüm tıbbi tedaviyi hukuka aykırı kılabileceği unutulmamalıdır. Eğer iyileştirme umutları tıbbi konsültasyon sırasında kasıtlı olarak yanlış bir şekilde hastaya sunuluyorsa veya hastanın fark edilebilir bir yanılgıya düşmesi söz konusu olmasına rağmen bu yanılgılar doktor tarafindan düzeltilmezse, bu aynı zamanda hastanın rızasını geçersiz kılarak yapılan müdahaleyi hukuka aykırı hale getirmektedir ${ }^{100}$. Doktor tarafından, yukarıda sayılan bu kriterleri karşılayan bir aydınlatma yoksa, yapılan müdahale hukuka aykırıdır ve doktor, müdahalenin gereği gibi yapılıp yapılmadığına bakılmaksızın, tüm sonuçlarından sorumludur ${ }^{101}$.

Aydınlatma yükümlülüğü, tıpkı konvansiyonel tıbbi müdahalelerde olduğu gibi, geleneksel ve tamamlayıcı tıbbi müdahale öncesi gerçekleştirilmeli ve hastanın rızası yazılı olarak alınmalıdır. Zira rızanın varlığı, tıbbi müdahalenin hukuka uygun sayılabilmesi için olmazsa olmaz bir şarttır. Aydınlatma yükümlülüğünün tıbbi müdahale öncesi hiç veya gereği gibi ifa edilmemesi veya hastanın rızasının alınmaması halinde, tıbbi müdahaleden doğan tüm olumsuz sonuçlara doktor katlanır. Ancak doktor, hastaya hiç veya gereği gibi bilgi vermemesinin hastanın kararını etkilemediğine ve hastanın uygun şekilde bilgilendirilse bile, aynı tıbbi müdahaleye rıza göste-

100 Bodenburg, s. 2829 vd.; Schmid, s. 2339 vd.; BGH, NJW, 2020, 1358 vd.; OLG Koblenz, NJW, 1996, 1600 vd., <https://beck-online.beck.de > E.T.: 13.01.2021.

101 Konuya ilişkin Alman Federal Yüksek Mahkemesi kararına göre, kural olarak henüz tanınmamış ve yerleşmemiş tedavi yöntemlerinin kullanılması, uygulamayı gerçekleştiren doktorun hukuki sorumluluğunu mutlaka doğuracağı anlamına gelmez. Zira tedavi yöntemlerinin seçimi noktasında doktorun geniş takdir yetkisi bulunmaktadır. Ancak doktor, farklı tedavi yöntemlerinin değerlendirmesinde, tedavi sonucunda beklenen faydalar ile şüphelenilen veya oluşan zararlar arasında dikkatli bir karşılaştırma yapmalıdır. Doktor bu değerlendirme sonucunda her zaman en güvenilir tedavi yöntemini seçmek zorunda değildir. Fakat doktorun tedavi seçiminde yüksek risk, somut olayda onu özel olarak kısıtlayıcı bir sebep olmalı veya doktor seçtiği bu tedavi yöntemine objektif bir gerekçe bulmalıdır. Tanınmamış ve yerleşmemiş bir yöntemin uygulanması, hastanın kendi kaderini tayin hakkını korumak için, hastanın bu yöntemin artıları ve eksileri hakkında bilgilendirilmesini gerektirir. Hastaya sadece işlemin risklerini ve başarısızlık riskini açıklamak değil, aynı zamanda planlanan prosedürün (henüz) tıbbi standart olmadığını ve etkinliğinin (henüz) istatistiksel olarak doğrulanmadığını açıklamak da gereklidir. Hasta, bu tedavinin risklerini almak isteyip istemediğini ve tedavinin başarı şansını tartabilmek için neye izin verdiğini bilmelidir. İlgili karar (ArzthaftungSorgfaltsmaßstab bei Anwendung einer Außenseitermethode) için bkz. BGH, NJW, 2007, 2774 vd.; Benzer Alman Federal Yüksek Mahkemesi kararları için bkz. BGH, NJW, 2006, 2477 vd.; BGH, NJW, 2007, s. 2767 vd.; BGH, NJW, 2011, s. 1089 vd; BGH, NJW, 2017, s. 2685 vd., <https://beck-online.beck.de $\geq$ E.T.: 13.01.2021; Söğüt, s. 630; Schubarth, s. 1090; Schumacher, Arzthaftungsrecht, s. 790 vd.; Vogeler, s. 697 vd.; Schmid, s. 2340. 
receğini kanıtlarsa kural olarak sorumluluktan kurtulur ${ }^{102}$. Konuya ilişkin olarak, hastanın kendi kaderini tayin hakkına zarar vermemek, aynı zamanda hastayı aydınlatma hatalarının kötüye kullanılmasını önlemek için, Alman Federal Yüksek Mahkemesi uzlaştırıcı bir çözüm getirmiştir. Buna göre, tedavi eden taraf, gerekli bilgiler verilmiş olsa bile, hastanın tedaviye rıza göstereceğini kanıtlamışsa, hasta yeterli bilgi karşısında dahi karar verme noktasında zorluk ve ikilem yaşayacağını kanıtlamalıdır ${ }^{103}$.

\section{Tıbbi Gereklilik (Endikasyon)}

\section{a. Genel Olarak}

Endikasyon, belirli bir klinik tablo için hangi tıbbi tedavinin gerekli olduğunun araştırılmasıdır. Kısaca tıbbi gereklilik veya zorunluluk olarak tanımlanan endikasyonun somut durumda yokluğu, ilgili tıbbi müdahalenin hukuka uygunluğunu engeller ${ }^{104}$.

Nitekim Hasta Hakları Yönetmeliği m. 12 uyarınca, "teşhis, tedavi veya korunma maksadı olmaksızın, ölüme veya hayati tehlikeye yol açabilecek veya vücut bütünlüğ̈nü ihlal edebilecek veya akli veya bedeni mukavemeti azaltabilecek hiçbir şey yapılamaz ve talep de edilemez." Benzer şekilde Tıbbi Deontoloji Nizamnamesi m. 13 uyarınca, "Tabip ve diş tabibi; teşhis, tedavi veya korunmak gayesi olmaksizın, hastanın arzusuna uyarak veya diğer sebeplerle, akli veya bedeni mukavemetini azaltacak her hangi bir şey yapamaz.". Dolayısıyla doktor, ancak tıbbi endikasyonun varlığ 1 halinde tıbbi müdahalede bulunabilir. Tıbbi endikasyon olmadığ 1 halde gerçekleştirilen tıbbi müdahaleler sonucunda, özel hukuk bağlamında, doktorun haksız fiil ve duruma göre (hasta ile doktor arasında sözleşme ilişkinin varlığına göre) sözleşme sorumluluğu söz konusu olabilir ${ }^{105}$.

Günümüzde, tıbbi endikasyonun yanı sıra sosyal ve psikolojik endikasyon da bu kapsamda kabul edilmektedir. Özellikle estetik müdahalelerde amaç, şifa bulmak değil; hastanın kendini psikolojik yönden daha iyi hisset-

102 Geiß/Greiner, Rn. 137; Vogeler, s. 705; BGH, NJW, 2007, 2770 vd., <https://beckonline.beck.de > E.T.: 23.01.2021.

103 İlgili karara göre hasta, eğer ilacın henüz onaylanmadığını bilseydi ve bu nedenle bilinmeyen bir yan etki riski varsa, bu ilacı almayacağını veya ciddi bir karar alma çatışmasına gireceğini kanıtlamalıdır, BGH, NJW, 2007, 2770 vd., <https://beck-online.beck.de > E.T.: 23.01.2021; Vogeler, s. 705; Geiß/Greiner, Rn. 138 vd.

104 Bkz. Y13HD., 25.01.2018 T., 2015/39259 E., 2018/573 K.; Y13HD., 01.03.2016 T., 2015/3276 E., 2016/6289 K., <https://www.kazancihukuk.com> E.T.: 05.04.2021.

105 Konuya ilişkin ayrıntılı bilgi için bkz. Ayan, s. 5 vd.; Hakeri, Tıp, s. 371 vd.; Şatır, s. $20 \mathrm{vd}$. 
mesini sağlamaya yöneliktir. Dolayısıyla estetik müdahaleler, psikolojik endikasyon olarak kabul edilebilir. Aynı şekilde çocukların sünnet edilmesi de sosyal bir endikasyon olarak sayılabilir. Sonuç olarak doktor; sosyal, psikolojik ve tıbbi gereklilik dışında hastaya müdahale edemez ${ }^{106}$.

\section{b. Geleneksel ve Tamamlayıcı Tip Uygulamalarında Tıbbi Gereklilik}

Sağlık Bakanlığı, Geleneksel ve Tamamlayıcı Tıp Uygulamaları Yönetmeliği'ne ait Ek-3'te, anılan her bir geleneksel ve tamamlayıc tıp uygulamalarına ilişkin endikasyon ve kontraendikasyon alanlarını belirlemiştir. İlgili ekte, tıbbi endikasyon alanlarına ilişkin belirlemenin oldukça geniş tutulduğu ve neredeyse insanoğlunun tüm sağlık şikayetlerinde, anılan geleneksel ve tamamlayıcı tıp yöntemlerinin uygulanabileceği öngörülmekte$\operatorname{dir}^{107}$.

Ayrıca Sağlık Bakanlığı, anılan tıbbi endikasyonların varlığ halinde, uygulamaların ancak konvansiyonel tıp tarafindan öngörülen standart tedaviyi destekleyici şekilde kullanılmasını öngörmektedir ${ }^{108}$. Buna göre hastalık, geleneksel ve tamamlayıcı tıp tarafından değil, öncelikle konvansiyonel tıp tarafından teşhis edilmeli ve teşhise göre standart tedavi başlanmalıdır. Ardından ilgili yönetmelikte anılan geleneksel ve tamamlayıcı tıp uygulamaları, standart tedavinin yanında, onu destekleyici ve tamamlayıcı nitelikte kullanılmalıdır. Zira ilgili yönetmelik m. 8/b. 4 uyarınca, "uygulamalar hastalı̆̆ın standart tedavisinin yerine geçecek ve devam eden tedaviyi aksatacak şekilde yapılamaz." Dolayısıyla ilgili hükme göre doktor, yönetmelikte anılan geleneksel ve tamamlayıcı tedavi yöntemlerini, hasta bir kişiye, sadece standart tedavinin yanında, onu destekleyici ve tamamlayıcı nitelikte uygulayabilir. Örnek vermek gerekirse; ilgili yönetmelik uyarınca kupa uygulaması, sadece belirtilen endikasyon alanlarında ${ }^{109}$ tedaviyi destekleyici

106 Akyıldız, s. 209; Özer, s. 132 vd.; Özgül, s. 262.

107 Nitekim Türk Tabipler Birliği de, ilgili yönetmeliği bu yönü ile eleştirmektedir. Bkz. Türk Tabipler Birliği, https://www.ttb.org.tr/haberarsiv_goster.php?Guid=673b997a9232-11e7-b66d-1540034f819c, (E.T.: 02.04.2021).

108 Ancak ilgili yönetmelikte Fitoterapi uygulamasına ilişkin bu yönde bir açıklama yapılmamıştır. Bir diğer ifadeyle, fitoterapi dışında anılan tüm tıp uygulamaları standart tedaviyi tamamlayıcı nitelikte kabul edilmelerine rağmen, fitoterapinin müstakil olarak da kullanılabilirliğine ilişkin bir belirsizlik bulunmamaktadır. Bunun sebebinin bu uygulamanın Sağlık Bakanlığı'nca geleneksel tıp uygulaması olarak kabul edilmesinden ileri geldiği kanısındayız.

109 Geleneksel ve Tamalayıcı Tıp Uygulamaları Yönetmeliği Ek-3 uyarınca, organik bir rahatsızlığı tanımlayan hastalarda immün sistemi güçlendirme, fibromiyalji sendromu, romatizmal hastalıklara ait kronik ağrı, eklem hareket kısıtlılı̆̆ı, sabah tutukluluğu, 
yöntem olarak kullanılmalıdır. İlgili yönetmeliğe göre, kupa uygulamasında uygulayıcı, bu uygulamanın hastalığı ortadan kaldıracağı veya tek başına tedavi edeceği gibi beyanlarda bulunamaz. Sonuç olarak; tıbbi bir müdahale olarak kabul edilmesi gereken kupa uygulaması, sadece yönetmelikçe belirtilen endikasyon alanlarından birine sahip kişilere uygulanabilecektir. Böylece sırf kupa uygulamasını merak ettiği ve tecrübe etmek istediği için bir kişiye kupa uygulaması gerçekleştirilemez. Aksi takdirde, endikasyon yokluğu sebebiyle, yapılan tıbbi müdahale hukuka aykırı hale gelmekte ve uygulayıcının hukuki sorumluluğu (somut şartlara göre haksız fiil veya sözleşme sorumluluğu) doğmaktadır.

Sağlık Bakanlığı'nın anılan uygulamaların, sadece standart tedaviyi destekleyici yönde olması gerektiği görüşünün aksine, doktrinde geleneksel ve tamamlayıcı tıp uygulamalarının müstakil olarak da hastalığın tedavisinde uygulanabileceği ve bunun hukuka aykırılık teşkil etmeyeceği görüşü bulunmaktadır ${ }^{10}$. Buna göre doktor, tedavi özgürlüğü uyarınca, hastanın rıza göstermesi şartıyla, standart tedavinin dışında yer alan uygulamalara başvurabilir. Böylece kural olarak doktorun standart tedavi yerine, geleneksel ve tamamlayıcı tıp uygulamalarını kullanmasında hukuki sorumluluğun oluşması için gerekli olan hukuka aykırılık unsuru oluşmaz. Zira doktor, tıp biliminin yerleşik bilgisini göz ardı etmediği sürece, kendisine tanınan tedavi özgürlügünün sonucu olarak, tıbbi hizmetinin türü ve kapsamı konusunda özgürce karar verebilir. Ancak doktorun tedavi özgürlüğü sınırsız da değildir. Tıbbi endikasyonun gerçekleşmesi sonucunda başlayan hastalığın teşhis ve teşhise uygun tedavi sürecinde, doktor iki hususa dikkat etmelidir. Buna göre doktor, tıbbi endikasyona uygun tedavi yöntemi olarak, standart dışı bir tedavi yöntemini seçmek istiyorsa, mutlaka haklı bir sebebe dayanmalıdır. Ayrica doktor, geleneksel ve tamamlayıcı tıp uygulaması seçmesi nedeniyle, standart tedavinin engellenmesine veya geciktirilmesine sebebiyet vermemelidir.

yorgunluk gibi durumlar, kas-iskelet sistemi mekanik ağrıları, diz ağrısı, migren ve gerilim tipi baş ağrısı gibi organik olmayan baş ağrıları, organik olmayan uyku bozuklukları, sindirim sistemi hastalıklarına ait bulantı, kusma gibi durumlar, nevraljilere bağlı ağrılar, inmeye bağlı gelişen hıçkırık, yorgunluk, afazi gibi durumlarda, kupa uygulaması için tıbbi endikasyonun varlığ 1 kabul edilmektedir.

110 Karş. Bodenburg, s. 2829 vd.; Schumacher, Arzthaftungsrecht, s. 787 vd.; Katzenmeier, Christian: BeckOK BGB (Hrsg.: Hau, Wolfgang/Poseck, Roman), 56. Auflage, Verlag C. H. Beck, München 2020, § 630a, Rn. 183; Müller/Raschke, s. 429; Vogeler, s. 700; Schubarth, s. 1089 vd.; Schmid, s. 2339 vd.; Hakeri, Geleneksel Tip, s. 35 . 
Geleneksel ve tamamlayıcı tıp uygulamaları açısından tıbbi gereklilik noktasında, en azından tıbbi bir fayda mümkün görünmelidir. Dolayısıyla seçilen yöntem, istenen tıbbi faydayı sağlamak için açıkça uygun değilse, hukuka aykırılığın doğmaması için gerekli olan endikasyon şartı ihlal edilmiş sayılır. Endikasyon şartının gerçekleşmesi için, kural olarak seçilen tedavi yönteminin faydasına ilişkin kanıt gereksinimi bulunmaktadır. Ancak burada kastedilen kanıt gereksinimi, seçilen yöntemin mutlaka istatiksel olarak etkinliğinin ispatlanması anlamında değildir. Nitekim her somut durumda, istatistiksel etkinlik kanıtının gerekli olmadığı kabul edilmekte$\operatorname{dir}^{111}$. Sonuç olarak, bilimsel bir değerlendirme için erişilebilir olan herhangi bir kanıta nihai olarak dayanabilecek makul bir fayda öngörüsü talep etmek uygun görünmektedir ${ }^{12}$.

Eğer somut durumda, hastalığın tedavisi olarak konvansiyonel standart yöntemler mevcutsa ve konvansiyonel tıp iyileşme noktasında daha kesin bir tedavi öngörüyorsa, doktor tarafından geleneksel ve tamamlayıcı tıp yöntemlerinin kullanılabilmesi için haklı sebepler bulunmalıdır ${ }^{113}$. Geleneksel ve tamamlayıcı tıp uygulamalarının hastalığın tedavisinde gerekli olabilmesi için sebeplerin objektif ve haklı olması şartı ile konvansiyonel tıbbi uygulamanın vaat ettiği başarı şansı, doktor tarafindan değerlendirilmeye tabi tutulmalıdır. Bununla birlikte doktor, başarı şansına ek olarak, örneğin tedavinin aciliyeti, hastalığın ciddiyeti, müdahalenin ciddiyeti ve hastanın kişilik özellikleri gibi, vakanın bireysel tüm koşullarını da dikkate almalıdır. Ancak daha ciddi hastalıklar söz konusu olduğunda, konvansiyonel tıp daha etkili yöntemler sağlamazsa veya daha etkili konvansiyonel tıbbi yöntem önemli risklerle (özellikle yan etkilerle) ilişkilendirilirse ve aydınlatılmış hasta bu riskli tedaviyi veya operasyonu kararlı bir şekilde reddederse, geleneksel ve tamamlayıcı tıbbi tedavinin kullanılması, doktor açısından haklı bir sebep teşkil edebilir ${ }^{114}$.

111 Schumacher, Arzthaftungsrecht, s. 790; BGH MedR 2008, 87 vd., $<$ http://www.springer.com> E.T.: 18.01.2021; OLG Stuttgart, VersR, 2003, 992 vd., $<$ https:// beck-online.beck.de > E.T.: 13.01.2021; Müller/Raschke, s. 428 vd.

112 Schumacher, Arzthaftungsrecht, s. 790; Benzer görüş için bkz. Sarıyev, s. 91 vd.

113 BGH, NJW, 2007, 2774 vd.; Benzer Alman Federal Yüksek Mahkemesi kararları için bkz. BGH, NJW, 2006, 2477 vd.; BGH, NJW, 2007, s. 2767 vd.; BGH, NJW, 2011, s. 1089 vd.; BGH, NJW, 2017, s. 2685 vd., <https://beck-online.beck.de > E.T.: 13.01.2021

114 Schumacher, Arzthaftungsrecht, s. 790; Keza Yargitay’a göre de, “Doktor, hastasinın zarar görmemesi için, mesleki tüm şartları yerine getirmek, hastanın durumunu tıbbi açıdan zamanında ve gecikmeksizin saptayı, somut durumun gerektirdiği önlemleri eksiksiz biçimde almak, uygun tedaviyi de yine gecikmeden belirleyip uygulamak zorun- 


\section{Tibbi Standart}

\section{a. Genel Olarak}

Tıbbi standart, güncel koşullara ve risklere sürekli olarak uyum sağlamayabilmek için değişken (dinamik) bir yapıya sahiptir. Tıbbi standart, tıbbi tedavi hedefine ulaşmak için gerekli olan ve denemelerde kendini kanıtlamış olan mevcut bilimsel bilgi ve tıbbi deneyim durumunu temsil etmektedir. Türk Tabipler Birliği'nin “Hekimlik Meslek Etiği Kuralları” m. 5 uyarınca, "hekimin öncelikli görevi, hastallklarl önlemeye ve bilimsel gerekleri yerine getirerek hastaları iyileştirmeye çalışarak insanın yaşamını ve sağlığını korumaktır. Meslek uygulamast sırasında insan onurunu gözetmesi de, hekimin öncelikli ödevidir. Hekim, bu yükümlülüklerini yerine getirebilmek için, gelişmeleri yakından izler." Dolayısıyla doktor, tıbbi standardın ne olması gerektiğini güncel gelişmeleri de dikkate alarak, yakından takip etmelidir ${ }^{115}$.

1997 yılında ülkemizce imzalanan ve 2003 yılında Resmi Gazete'de yayınlanarak yürürlüğe giren Biyotıp Sözleşmesi m. 4 uyarınca, araştırma dahil, sağlık alanında herhangi bir müdahalenin ilgili mesleki yükümlülükler ve standartlara uygun olarak yapılması gerekmektedir.

Yargıtay'a göre ${ }^{116}$ tıbbi standart, hekimin tedavinin amacına ulaşması için gerekli olan ve denenerek ispatlanmış bulunan, hekim tecrübesi ve doğa bilimlerinin o anki ulaştığı düzeyi ifade etmekte olup, denenmiş ve bilinen

dadır. Asgari düzeyde dahi olsa, tereddüt doğuran durumlarda, bu tereddüdünü ortadan kaldıracak araştırmalar yapmak ve bu arada da, koruyucu tedbirleri almakla yükümlüdür. Çeşitli tedavi yöntemleri arasında seçim yapılırken, hastanın ve hastalığın özellikleri göz önünde tutulmall, onu risk altına sokacak tutum ve davranışlardan kaçınılmalı ve en emin yol seçilmelidir.", YHGK., 13.04.2011 T., 2010/13-717 E., 2011/129 K. $<$ https://www.legalbank.net> E.T.: 03.02.2021.

115 Hakeri, Geleneksel Tıp, s. 19 vd.; Benzer şekilde Hasta Hakları Yönetmeliği m. 11 uyarınca, "Hasta, modern tıbbi bilgi ve teknolojinin gereklerine uygun olarak teşhisinin konulmasını, tedavisinin yapılmasını ve bakımını istemek hakkına sahiptir. Tababetin ilkelerine ve tababet ile ilgili mevzuat hükümlerine aykırl veya aldatıcı mahiyette teşhis ve tedavi yapılamaz". Yine Tıbbi Deontoloji Nizamnamesi m. 13 uyarınca, "Tabip ve diş tabibi, ilmî icaplara uygun olarak teşhis koyar ve gereken tedaviyi tatbik eder. Bu faaliyetlerinin mutlak surette şifa ile neticelenmemesinden dolayl, deontoloji bakımından muaheze edilemez. Tababet prensip ve kaidelerine aykirl veya aldatici mahiyette teşhis ve tedavi yasaktır. Tabip ve diş tabibi; teşhis, tedavi veya korunmak gayesi olmaksızın, hastanın arzusuna uyarak veya diğer sebeplerle, akli veya bedeni mukavemetini azaltacak her hangi bir şey yapamaz".

116 Y15HD., 19.11.2018 T., 2018/4953 E., 2018/4526 K.; Y15HD., 26.11.2018 T., 2018/4621 E., 2018/4686 K.; Y15HD., 26.02.2019 T., 2018/5523 E., 2019/801 K. $<$ https://www.legalbank.net> E.T.: 03.02.2021. 
temel meslek kurallarıdır. Alman Federal Yüksek Mahkemesi'ne göre ${ }^{117}$ ise tıbbi standart, tedavinin amacına ulaşabilmesi için gerekli olan ve denemeler sonucunda kanıtlanmış bilimsel bilgi ve tıbbi deneyimin mevcut durumunu temsil etmektedir. Tibbi standart, bilimsel bilgi, tıbbi deneyim ve profesyonel kabulün birleşimi olmalıdır.

\section{b. Geleneksel ve Tamamlayıcı Tip Uygulamalarında Tibbi Standart}

Konvansiyonel tıbbi müdahaleler ve bilinen tedavi olanakları, hastalıkların tedavisinde çoğunlukla olumlu sonuçlar vermekle birlikte, sağlık sistemi süreçlerinin yavaş işlemesi, mevcut ve bilinen tedavi seçeneklerinin yetersizliği hastaları denenmemiş ve test edilmemiş yeni veya farklı seçeneklere itmektedir. Ancak bu yöndeki bir eğilim tehlikeleri ve riskleri de beraberinde getirebilir ve tıbbi standarttan sapma kaçınılmaz olabilir ${ }^{118}$. Doktor, tıbbi standardı tıbbi müdahalenin her aşamasında gerçekleştirmeye çalışmalıdır. Bu bağlamda doktor, hastalığın teşhisi aşamasında kendisinden beklenen özen yükümlülüğünü yerine getirmeli ve teşhise uygun tedavinin uygulanması aşamasında da yine özen yükümlülüğü gereğince hareket etmelidir $^{119}$.

117 Kreße, Bernhard: “Ärztliche Behandlungsfehler durch wirtschaftlich motiviertes Unterlassen”, MedR, S. 25, Y. 2007, s. 394

118 Müller/Raschke, s. 428; Bodenburg, s. 2823; Vogeler, s. 701; BGH, MedR, 1987, 234 vd. , <http://www.springer.com> E.T.: 18.01.2021; BGH, NJW, 2006, 2477; BGH, NJW, 2007, 2775, <https:// beck-online.beck.de $\geq$ E.T.: 13.01.2021.

119 Konuya ilişkin Yargıtay kararına göre, "Hekim, tababeti yerine getirirken, tıbbı uygularken kişinin yaşamasını düzenlemek, să̆lı̆̆ını sağlayabilmek amacıyla çeşitli faaliyetlerde bulunmaktadır. Bu faaliyetler hastalı̆̆ın teşhisi, gerekli ilaçların verilmesi, cerrahi müdahalelerin yapılması, hastalı̆̆ın devamlı olarak gözetilmesi, gerektiğinde yan etkili tedavi yollarına, yeni usullere başvurulması gibi çeşitli konuları kapsamaktadır. İste hekim bu faaliyetlerde bulunurken bazı mesleki şartları yerine getirmek hastanın durumuna değer vermek ve geniş bir deyimle tıp biliminin kurallarını gözetip uygulamak zorundadır. Aksi halde hekim tıp biliminin verilerini yanlış ya da eksik uygulamıssa, mesleğine gerektirdiği özel görevlere gereği ve yeteri kadar uymamıssa mesleki kusuru var demektir ki, bu eylem ve davranış da hukuka aykırılık nedeniyle sorumluluğunu gerektirecektir.”, Y4HD., 07.03.1977 T., 1976/6297 E., 1977/12541 K.; Benzer Yargıtay kararına göre, "Çeşitli tedavi yöntemleri arasında bir seçim yapılırken, hastanın ve hastalığın özellikleri göz önünde tutulmak, onu risk altına sokacak tutum ve davranışlardan kaçınılmak ve en emin yol seçilmelidir. Gerçekten de müvekkil (hasta), mesleki bir iş gören vekilden, tedavinin bütün aşamalarında titiz bir ihtimam ve dikkat göstermesini beklemek hakkına sahiptir. Gereken özeni göstermeyen vekil, vekâleti gereği gibi ifa etmemiş sayllmalıdır. Sözleşme tarihinde yürürlükte bulunan 6098 Sayll TBK'nun 502 ve devamı maddelerinde düzenlenen hükümler uygulanacaktır. TBK'nun 506. maddesinin 2. fikrasında, "vekil, (hekim/hastane) üstlendiği iş ve hizmetleri, vekâ- 
Doktor, hastalığın tedavisinde kullanılacak yöntemi seçme özgürlüğ̈̈ne sahiptir. Tedavi seçimi, doktorun öncelikli meselesidir ${ }^{120}$. Bunun altında yatan düşünce, doktora her zaman bireysel hareket alanı verilmesi gerektigidirr $^{121}$. Doktor, tıp biliminin yerleşik bilgisini göz ardı etmediği sürece, kendisine tanınan tedavi özgürlüğünün sonucu olarak, tıbbi hizmetinin türü ve kapsamı konusunda özgürce karar verir. Ancak doktorun belirli bir teşhis şekli ve belirli bir tedavi prosedürü için kararı, her durumda, hastanın çeşitli fiziksel, psikolojik ve sosyal yönleri dikkate alınarak, somut olaydaki fayda ve risklerin değerlendirilmesiyle karakterize edilmelidir. Özellikle bu değerlendirme geleneksel ve tamamlayıcı tıp açısından daha önemlidir, zira burada daha önce kullanılanlar dışında tanınmayan bir durum söz konusudur. Dolayısıyla özellikle hastalığın teşhisi noktasında, geleneksel ve tamamlayıcı tıp kullanılmamalıdır. Konvansiyonel tıp yöntemleri yerine geleneksel ve tamamlayıc1 yöntemlerin kullanılması, iyileşme başarısı elde etmek için basit bir şansla, bedensel zarar riskini iki katına çıkarmak anlamına gelir ${ }^{122}$.

let verenin (hastanin) hakl menfaatlerini gözeterek, sadakat ve özenle yürütmekle yükümlüdür. Ayrıca, 3. fikrada, özen borcundan doğan sorumluluğun belirlenmesinde, benzer alanda iş ve hizmetleri üstlenen basiretli bir vekilin göstermesi gereken davranış esas alınır." denilmektedir. Yine 04.04.1997 tarihinde imzalanan ve 09.12.2003 tarih ve 25311 Sayıl Resmi Gazete de yayımlanıp yürürlüğe giren Avrupa Biyotıp Sözleşmesi'nde iç hukukumuzun bir parçası haline gelmiş olup, sözleşmenin amaç başlıklı 1 . maddesi bu sözleşmenin "tarafları tüm insanların hayatını ve kimliğini koruyacak ve biyoloji ve tıbbın uygulanmasında, ayırım yapmadan herkesin, bütünlüğ̈̈ne ve diğer hak ve özgürlüklerine saygl gösterilmesini güvence altına almakla yükümlüdürler”, yine 4. maddesinde ise, "araştırma dahil, sağlık alanında herhangi bir müdahalenin ilgili mesleki yükümlülükler ve standartlara uygun olarak yapılması gerekir” düzenlemesi mevcuttur. Avrupa Biyotıp Sözleşmesi yazılı olan veya yazılı olmayan meslek kurallarına uygun müdahaleyi güvence altına almaktadır. Ayrica, uygulamanın tedavi ya da yaşam kalitesinin yükseltilmesi amacına yönelmesi zorunlu olduğu belirtilmektedir. Burada kastedilenin tıbbi standartlar olduğu konusunda bir duraksama bulunmamalıdır.", Y15HD., 22.05.2019 T., 2017/2329 E., 2019/2441 K., <https://www.kazancihukuk. com> E.T.: 05.04.2021

120 BGH, NJW, 1988, 763 vd.; BGH, NJW, 2014, 1529 vd., <https:// beck-online.beck.de > E.T.: 21.01.2021; BGH, MedR, 1989, 139, <http://www.springer.com> E.T.: 18.01.2021.

121 Katzenmeier, BeckOK, § 630a, Rn. 183; Müller/Raschke, s. 429.

122 Katzenmeier, BeckOK, Rn. 183; Bodenburg, s. 2824; Müller/Raschke, s. 429; Vogeler, s. 700; BGH, MedR, 1987, 234 vd., <http://www.springer.com> E.T.: 18.01.2021; BGH, NJW, 2006, 2477; BGH, NJW, 2007, 2775, <https:// beckonline.beck.de > E.T.: 13.01.2021; Benzer görüş için bkz. Somer, Pervin: "Ülkemizde Tamamlayıcı ve Alternatif Tıbbın Hukuki Dayanağı ve Sorumluluk Alanları Üzerine”, Sağlık Düşüncesi ve Tıp Kültürü Dergisi, S. 22, Y. Mart-Nisan-Mayıs 2011-2012, s. 48 vd. 
Geleneksel ve tamamlayıcı tedavi yönteminin doktor tarafından seçilmesi, doğru bir şekilde gerçekleştirilmesi ve herhangi bir komplikasyon durumunda müdahale edilmesi sırasında doktorun özen yükümlülüğü bulunmaktadır. Özellikle tedavi yöntemi seçme aşamasında gerekli özeni gösterme yükümlülüğü, doktorun hasta üzerinde kesin ve kapsamlı teşhis önlemlerini almasını gerektirir. Doktor, bir tedavi yöntemi seçerken, her zaman tedavinin avantaj ve dezavantajlarını dikkatlice tartmakla yükümlüdür. Bununla birlikte doktor, her zaman en güvenli tedavi yöntemini seçmek zorunda değildir. Ancak doktor, daha az güvenli bir tedavi yöntemini seçmişse, bunun mutlaka gerekçelendirilmesi gerekmektedir. Konvansiyonel tıbbın hastalığa ilişkin bilimsel verileri ne kadar güvenilirse, doktorun geleneksel ve tamamlayıcı tedavi yöntemini seçmesindeki gerekçelendirme zorunluluğu bir o kadar haklı sebebe dayanmalıdır. Doktor hastalığın tedavisinde, iyileşme başarısının imkansız olduğu açık olan bir tedavi yöntemi kullanırsa veya açıkça uygunsuz ve beyhude tedbirler alırsa, tedavi yöntemi seçiminde özen yükümlülügünü ihlal etmiş sayılır. Dolayısıyla burada doktor tarafından sorulması gereken soru, tedavinin hala istenen iyileşme başarısını sağlamak için uygun görünüp görünmediğidir ${ }^{123}$.

Özen yükümlülüğünün hem karar aşamasında, hem de uygulama aşamasında hukuken şart koşulması sayesinde, geleneksel ve tamamlayıcı tıbbi yöntemlerde en azından yasal kontrol gerçekleştirilebilir. Örneğin, münferit vakalarda geleneksel ve tamamlayıcı tıbbi yöntemin seçimi, özen yükümlülüğü ışığında kabul edilemez olabilir. Dolayısıyla bu noktada, hastayı zararlı veya tıbbi olarak yararsız önlemlerden korumak ve tıp mesleğinin güvenilirliğini gerekli şekilde sürdürmek amacıyla, tıbbi tedavi özgürlüğüne geleneksel ve tamamlayıcı tıbbi uygulamalar açısından yasal bir sınır konulmalidır. Doktor, mevcut standart tedavi yöntemi yerine geleneksel ve tamamlayıcı tedavi yöntemini seçmesi halinde, mutlaka haklı bir nedene dayanma${ }_{11 d 1 r^{124}}$. Özellikle (kanser gibi) hayati tehlike arz eden hastalıklarda geleneksel ve tamamlayıcı tıbbi yöntemlerin kullanımında böyle bir sınır yerinde

123 Müller/Raschke, s. 430; Nitekim Hasta Hakları Yönetmeliği mi. 14'te de doktorun özen yükümlülüğüne değinilmiştir. Buna göre "sağllk personeli, hastanın durumunun gerektirdiği tıbbi özeni gösterir. Hastanın hayatını kurtarmak veya sağlı̆̆ını korumak mümkün olmadığı takdirde dahi, ıstırabını azaltmaya veya dindirmeye çalışmak zorunludur."

124 Schumacher, Arzthaftungsrecht, s. 789; Bodenburg, s. 2829 vd.; Hauck, Ernst: "Rechtsgrundlagen der medizinischen Indikationsstellung", NJW, Heft 46, Y. 2013, s. 3334 vd.; Hakeri, Geleneksel Tip, s. 35. 
olacaktır $^{125}$. Örneğin, kanser gibi zamanla yarışılan ve erken müdahalenin önemli olduğu ölümcül hastalıklarda, öncelikle konvansiyonel standart tedavi uygulanmalıdır. Ancak konvansiyonel tıp tarafından tüm çarelerin tüketildiği bir kanser türünde ve derecesinde, en azından hastalığın etkilerinden kurtulmak ve hastayı rahatlatmak açısından geleneksel ve tamamlayıcı tıp uygulamasına başvurulabilir.

Belirli bir hastalığın tedavisinde geleneksel ve tamamlayıcı tıbbi yöntemin uygulanmasını uygun gören doktorun, yalnızca seçilen yöntemle ilgili eğitim ve sertifika almış olması yeterli değildir; aynı zamanda aynı hastalığın tedavisinde kullanılan konvansiyonel tıptaki prosedürleri de bilmesi gerekmektedir. Geleneksel ve tamamlayıcı tıbbi yöntemi uygulamayı seçen doktorun, bu seçimde özen yükümlülüğünü yerine getirdiğinin kabulü için, doktorun tüm tedavi alternatiflerini bilmesi, dikkate alınan yöntemin artı ve eksilerini bilinçli bir şekilde değerlendirmesi şarttır. Geleneksel ve tamamlayıcı tıbbı kullanırken, doktorun konvansiyonel tıbbi yönteme kıyasla, ilgili yöntemin beklenen başarı şansını ve öngörülebilir veya şüpheli risklerini dikkatlice incelemesi ve standart tedavi ile karşılaştırması özellikle gerekli$\operatorname{dir}^{126}$.

Alman Federal Yüksek Mahkemesi, doktorun tedavi seçiminin özen yükümlülüğünün ihlali sonucunda hukuki sorumluluğa yol açıp açmadığının belirlenmesinde, somut olayda kendisinden beklenilen tıbbi bilgi ve deneyim ışığında, hastalığın teşhisinde özellikle tedavisinde doktorun makul kararlar alıp almadığını incelemektedir. Bu inceleme sonucunda hukuka aykırılığın doğması için ise, somut olayda seçilen yöntemin tıbbi olarak gerekçelendirilebilir olmaması gerekmektedir ${ }^{127}$.

Doktorun tedavi seçimindeki özgürlüğü ve hareket alanının genişliğinin aksine, tedavinin uygulanması sırasında tıbbi standardın doktor tarafindan sağlanması noktasında, aynı hareket alanı bulunmamaktadır ${ }^{128}$. Tibbi stan-

125 Karş. BGH, NJW, 1960, s. 2253 vd.; OLG Koblenz, NJW, 1996, 1600 vd., $<$ https://beck-online.beck.de > E.T.: 13.01.2021; Kassel, Martin Estelmann: "Placeboeffekte-interdisziplinär betrachtet", NZS, Heft 13, Y. 2018, s. 526 vd.; Söbbing, Thomas: "Rechtsfragen homöopathischer Arzneimittel", InTer, S. 3, Y. September 2019, s. 127 vd.

126 Vogeler, s. $701 \mathrm{vd}$.

127 Vogeler, s. 701; BGH, MedR, 1987, $234 \mathrm{vd}$. , <http://www.springer.com> E.T.: 18.01.2021; BGH, NJW, 2006, 2477; BGH, NJW, 2007, 2775; BGH, NJW, 2011, s. 1089 vd.; BGH, NJW, 2017, s. 2685 vd., <https://beck-online.beck.de > E.T.: 13.01.2021.

128 Konuya ilişkin Yargıtay kararına göre, "Hekim să̆lıkla ilgili fiillerde, rızayı sağladıktan sonra tıp biliminin sınırları içinde hareket etmek yükümlülüğ̈̈ altındadır ve hastanın 
dardın varlığından bahsedilmek için, gerçekleştirilecek tıbbi müdahalenin bilimsel bilgiye, tıbbi deneyimlere dayanması ve meslek çevresinde kabul görmüş olması gerekmektedir. Bahsi geçen bu kriterlerin yokluğu halinde, tıbbi standardın varlığından söz edilemez. Doktor, tıbbi standardın kusurlu bir şekilde yetersiz kalmasından dolayı sorumludur. Tıbbi standardın kusurlu bir biçimde doktor tarafindan ihlali halinde sorumluluğun öngörülmesi, hastayı koruyucu ve doktorun davranışını yönlendirici işleve sahip itici bir güçtür. Gerek konvansiyonel tıp uygulamalarında, gerekse geleneksel ve tamamlayıcı tıp uygulamalarında, uygulamaları gerçekleştiren yetkili kişilerin tıbbi standardı gerçekleştirmeleri şarttır. Ancak konvansiyonel tıp uygulamalarına nazaran, geleneksel ve tamamlayıc tıp uygulamalarının her birinde bu standardı gerçekleştirmek oldukça zordur. Zira geleneksel ve tamamlayıcı tedavi yöntemlerinin pozitif bilimlere dayanmaması, çoğu zaman bilimsel deneylerin süzgecinden geçirilmemesi, etkinliğinin ve risklerinin belirsizliği, bilimsel verilerle kanıtlanmamış olması ${ }^{129}$ ve bilimsel yönden fikir birliği eksikliği ile karakterize olması vakaların büyük çoğunluğunda tıbbi standarttan sapma anlamına gelmektedir. Bununla birlikte, tıbbi standarttan her türlü sapma, malpraktis sebebiyle doktorun hukuki sorumluluğuna sebep olmaz. Burada, her küçük sapmanın bir iyileştirme girişimi olarak görülmesi gerekip gerekmediği veya sapmanın önemli olup olmadığı, hastanın iyileşmesi amacıyla tıbbi standartlardan kasıtlı olarak sapmanın var olup olmadığı ve doktorun hastanın rızası olmadan tıbbi standarttan sapıp sapmadığını değerlendirmek gerekir. Bu durum, hastalık daha önce bilinmediği ve bu nedenle yeni tedavi yöntemlerinin kaçınılmaz olarak denendiği için standart tıbbi bir tedavinin mevcut olmaması halinde de geçerlidir ${ }^{130}$.

Sonuç olarak, geleneksel ve tamamlayıcı tıbbi yöntemlerin kullanılmas1, tıbbi standarttan sapma anlamına gelmektedir, ancak bu sapma tek başına doktorun tedaviyi uygulama hatası anlamına gelmemektedir. Geleneksel ve tamamlayıcı tıp uygulamaları, bireysel iyileşme teşebbüsleri olarak görülebilir. Bu yüzden bu uygulamalarda asıl önemli olan, doktorun özen

rızasının kapsamına bağlı bulunmamaktadır.”, Y4HD., 07.03.1977 T., 1976/6297 E., 1977/12541 K., <https://www.kazancihukuk.com> E.T.: 05.04.2021.

129 Khan, Abdul Sattar/Aktürk, Zekeriya: "Tamamlayıcı ve Alternatif Tedaviler Ne Kadar Kanıta Dayalı?”, Sağlık Düşüncesi ve Tıp Kültürü Dergisi, S. 22, Y. Mart-Nisan-Mayıs 2012, s. 16 vd.; Taş̧̧ı, s. 50.

130 Bodenburg, s. 2825; Schumacher, Arzthaftungsrecht, s. 788; Vogeler, s. 700 vd.; Kreße, s. 394; Katzenmeier, Christian: "Rechtsfragen der Placebobehandlung", MedR, S. 36, Y. 2018, s. 373; Hakeri, Geleneksel Tıp, s. 23; Müller/Raschke, s. 429 vd. 
yükümlülügüü ve aydınlatma yükümlülügüüür. Doktorun bu yükümlülüklerinin yoğunluğu ve kapsamı, özellikle geleneksel ve tamamlayıcı tıp uygulamalarında, konvansiyonel tıbbi uygulamalara nazaran, artmalıdır ${ }^{131}$. Konuya ilişkin olarak Alman Federal Yüksek Mahkemesi’ne göre ${ }^{132}$, tıbbi standardın dışında bir tedavi yöntemi kullanılıyorsa, bu noktada gereken özen yükümlülüğü için temel ölçüt, dikkatli bir doktorun (ein vorsichtiger Arzt) göstereceği özendir ${ }^{133}$. Benzer şekilde Yargitay’a göre ${ }^{134}$, özen yükümlülüğünün ihlalinde dikkate alınması gereken ölçüt, zararı meydana getirenin sübjektif niteliklerine bakılmaksızın, tedbirli bir doktorun aynı hal ve şartlar altında göstereceği mutat özenden ibarettir. Zira hasta, tedavisini üstlenen meslek mensubu doktorundan tedavisinin bütün aşamalarında mesleğin gerektirdiği titiz bir ihtimam ve dikkati göstermesini, beden ve ruh sağlığı ile ilgili tehlikelerden kendisini bilgilendirmesini güven içinde beklemek hakkına sahiptir ${ }^{135}$.

Alman hukukunda konuya ilişkin olarak Alman Medeni Kanunu'nda (§ 630a/Abs. 2 BGB) bir hüküm yer almaktadır. İlgili maddeye göre tedavi, aksi kararlaştırılmadıkça, tedavi sırasında var olan genel kabul görmüş mesleki (tıbbi) standartlara göre yürütülmelidir. Yukarıda da değinildiği üzere, geleneksel ve tamamlayıcı tıbbi yöntemlerin fayda ve risklerinin bilimsel verilerle kanıtlanmamış olması sebebiyle, bu yöntemlerde çoğu zaman tıbbi standarttan sapma meydana gelebilmektedir. Dolayisıyla $\S 630 \mathrm{a} / \mathrm{Abs} .2$ BGB'nin varlığı sebebiyle, böyle bir sapmanın meydana gelme ihtimaline karş1, doktorun sorumluluğunun doğmaması için doktor ile hastanın aksini kararlaştırması gerekmektedir. Ancak doktrinde ${ }^{136}, \S 630 \mathrm{a} /$ Abs. 2 BGB'nin dar yorumlanması gerektiği kabul edilmektedir. Buna göre, hastaları koru-

131 Damm, s. 738 vd.; Bodenburg, s. 2825; Schumacher, Arzthaftungsrecht, s. 788; Vogeler, s. 700 vd.; Kreße, s. 394; Katzenmeier, Placebo, s. 373; Müller/Raschke, s. 429 vd.

132 BGH, NJW, 2007, s. 2775, <https://beck-online.beck.de > E.T.: 21.01.2021.

133 Spickhoff, Andreas: "Erforderliche Sorgfalt und Umfang der Aufklärungspflicht bei Anwendung einer Außenseitermethode", MedR, S. 26, Y. 2008, s. 87 vd.

134 Karş. Y13HD., $14.10 .1974 \quad$ T., $1973 / 2637 \quad$ E., $1974 / 2492 \quad$ K. $<$ https://www.legalbank.net> E.T.: 02.02.2021.

135 Y13HD., 10.10.2006 T., 2006/10068 E., 2006/13288 K. <https://www.legalbank.net $\geq$ E.T.: 02.02.2021.

136 Konuya ilişkin ayrıntılı bilgi için bkz. Schumacher, Katrin: Alternativmedizin: Arzthaftungsrechtliche, arzneimittelrechtliche und sozialrechtliche Grenzen ärztlicher Therapiefreiheit, Kölner Schriften zum Medizinrecht, Springer, Berlin 2017, s. 115 vd.; Karş. BGH, NJW, 2007, s. 2767 vd.; BGH, NJW, 2007, s. 2774 vd., <https://beckonline.beck.de > E.T.: 21.01.2021. 
mak amacıyla geleneksel ve tamamlayıcı tıbbi yöntemlerde, doktorun özen ve aydınlatma yükümlülügünün kapsamı ve yoğunluğu genişletilmiştir. Ayrıca konvansiyonel tıbbi uygulamalara nazaran genişleyen bu yükümlülüklere ek olarak, bir de ayrı bir anlaşmanın dayatılmasını gerekçelendirmek zor görünmektedir ${ }^{137}$.

\section{Komplikasyon Yönetimi}

\section{a. Genel Olarak}

Komplikasyon, tıbbi standartlara uygun bir müdahale sonucu oluşan, tıbben istenmemekle birlikte, tıp çevreleri tarafından öngörülebilen ve hukuken izin verilen risklere denmektedir. Her tıbbi müdahale, riskleri ve yan etkileri beraberinde getirebilir. Somut durumda, doğru teşhis, tıbbi standartlara uygun doğru tedavi uygulanmasına rağmen ve doktor tarafindan gerekli özenin gösterilmesine rağmen, bazı istenmeyen ancak öngörülebilen sonuçlar ortaya çıkabilmektedir. Kural olarak böyle bir durumda, tıbbın kurallarına uygun olarak gerçekleştirilen müdahalelerden doktor veya hastane sorumlu tutulmamaktadır ${ }^{138}$. Zira meydana gelebilecek istenmeyen ancak öngörülebilen bu sonuçlardan doktorun sorumlu olabilmesi için kusur şartı aranmaktadır. Kusurun varlığı için ise, doktorun tıbbi müdahale sırasında veya sonrasında özen yükümlülüğ̈̈nü yerine getirip getirmediğine bakılmalıdır ${ }^{139}$.

Doktor ile hasta arasında yer alan sözleşmenin hukuki niteliği istisnai haller dışında ${ }^{140}$, vekalet sözleşmesi olarak kabul edilmektedir ${ }^{141}$. Nitekim

137 BGH, NJW, 2007, s. 2767 vd.; BGH, NJW, 2007, s. 2774 vd., <https://beckonline.beck.de > E.T.: 21.01.2021.

138 Akyıldız, s. 210 vd.; Hakeri, Hakan: "Tip Hukukunda Malpraktis ve Komplikasyon Ayrımı”, Toraks Cerrahi Bülteni, C. 5, S. 1, Y. Mart 2014, s. 23 vd.; Sarıyev, s. 108 vd.

139 Hakeri, Komplikasyon, s. 24; Sarıev, s. 115 vd.; Özgül, s. 152 vd.; Y13HD., 09.05.2000 T., 2000/1446 E., 2000/4438 K.; Y13HD., 05.02.2007 T., 2007/16180 E., 2007/1248 K.; Y13HD., 08.07.2005 T., 2005/3645 E., 2005/11796 K., $<$ https://www.legalbank.net> E.T.: 05.04.2021.

140 Yargıtay'a göre tedavi niteliği olmayan tıbbi müdahaleler, eser sözleşmesinin kapsamında ele alınmalıdır. İlgili karara göre, "Bir hasta ile onu tedavi eden doktor ve bir avukat ile onun müvekkili arasındaki ilişki, vekalet sözleşmesinin konusunu oluşturur. Doktor, hastasına tıbbi yardımda ve avukat da hukuki yardımda bulunmayı taahhüt ederler; ancak, hastayı iyileştirme ve davay kazanma gibi bir sonucun taahhüdü, vekalet sözleşmelerinde söz konusu olamaz. Hasta ölse veya dava kaybedilse dahi, tıbbi yardımda bulunan doktor ile hukuki yardımda bulunan avukat, yaptzklar yardımın karşıllı̆̆ olan ücrete hak kazanırlar ve kusurları dışında sorumlu olamazlar. Eser (istisna) sözleşmelerinde ise, sadece bir hizmette bulunmak değil, aynı zamanda "Eser" denilen olumlu-olumsuz bir sonucun taahhüdü söz konusudur. Sonuç gerçekleşmezse, 
TBK. m. 506/f. 2 uyarınca, vekil üstlendiği iş ve hizmetleri, vekalet verenin haklı menfaatlerini gözeterek, sadakat ve özenle yürütmekle yükümlüdür. Yargıtay'ın konuya ilişkin kararlarına göre $\mathrm{de}^{142}$, “vekil, vekalet görevine konu işi görürken yöneldiği sonucun elde edilmemesinden sorumlu değil ise de, bu sonuca ulaşmak için gösterdiği çabanın, yaptı̆̆ işlemlerin, eylemlerin ve davranışların özenli olmayışından doğan zararlardan dolay sorumludur. Vekilin sorumluluğu, genel olarak işçinin sorumluluğuna ilişkin kurallara bağlldır. Vekil, işçi gibi özenle davranmak zorunda olup, en hafif kusurundan bile sorumludur. $O$ nedenle, doktorun meslek alanı içinde olan bütün kusurlarl, hafifte olsa, sorumluluğun unsuru olarak kabul edilmelidir. Doktor, hastasının zarar görmemesi için, mesleki tüm şartlar yerine getirmek, hastanın durumunu tıbbi açıdan zamanında ve gecikmeksizin saptayıp, somut durumun gerektirdiği önlemleri eksiksiz biçimde almak, uygun tedaviyi de yine gecikmeden belirleyip uygulamak zorundadır. Asgari düzeyde dahi olsa, tereddüt doğuran durumlarda, bu tereddüdünü ortadan kaldıracak araştırmalar yapmak ve bu arada da, koruyucu tedbirleri almakla yükümlüdür. Çeşitli tedavi yöntemleri arasında bir seçim yapılırken, hastanın ve hastalı̆̆ın özellikleri göz önünde tutulmall, onu risk altına sokacak tutum ve davranışlardan kaçınılmal ve en emin yol seçilmelidir. Gerçekten de müvekkil (hasta), mesleki bir iş gören doktor olan vekilden, tedavinin bütün aşamalarında titiz bir ihtimam ve dikkat göstermesini beklemek hakkına

meydana gelen zarardan yüklenici sorumlu olur. Bir diş doktorunun, kanal tedavisi değil de, takma diş yapması (protez) işi ve bir cerrahın tedavi değil de güzellik amacıyla insan vücudu üzerindeki tıbbi müdahalesi (olayımızda olduğu gibi) işi, TBK'nun 355 ve devamı maddelerinde düzenlenmiş bulunan istisna (eser) sözleşmesinin konusunu oluşturur.”, Y15HD., 03.11.1999 T., 1999/4007 E., 1999/3868 K., $<$ https://www.kazancihukuk.com> E.T.: 05.04.2021.

141 Y13HD., 25.04.2002 T., 2002/2589 E., 2002/4560 K.; Y13HD., 08.06.2015 T., 2014/ 31178 E., 2015/18961 K.; Y13HD., 06.03.2003 T., 2002/13959 E., 2003/2380 K.; Y13HD., 09.04.2003 T., 2003/711 E., 2003/4255 K.; Y13HD., 23.05.2018 T., 2015/ 27853 E., 2018/6133 K. <https://www.legalbank.net $\geq$ E.T.: 02.02.2021.

142 Y13HD., 08.06.2015 T., 2014/31178 E., 2015/18961 K.; Benzer Yargitay kararları için bkz. Y13HD., 06.03.2003 T., 2002/13959 E., 2003/2380 K.; Y13HD., 09.04.2003 T., 2003/711 E., 2003/4255 K.; Y13HD., 26.10 .2004 T., 2004/6493 E., 2004/5431 K.; Y13HD., 15.02.2005 T., 2005/11677 E., 2005/18599 K.; Y13HD., 08.07.2005 T., 2005/ 3645 E., 2005/11796 K.; Y13HD., 09.06.2006 T., 2006/6683 E., 2006/9443 K.; Y13HD., 13.04.2006 T., 2006/905 E., 2006/5549 K.; Y13HD., 19.10.2006 T., 2006/ 10057 E., 2006/13842 K.; Y13HD., 18.09.2008 T., 2008/4519 E., 2008/10750 K.; Y13HD., 15.09.2014 T., 2013/26330 E., 2014/27050 K.; Y13HD., 18.11.2015 T., 2014/ 26571 E., 2015/33584 K.; Y13HD., 23.05.2018 T., 2015/27853 E., 2018/6133 K. $<$ https://www.legalbank.net $\geq$ E.T.: 05.04.2021. 
sahiptir. Gereken özeni göstermeyen vekil, vekaleti gereği gibi ifa etmemiş sayılmalıdır." Dolayısıyla doktor, özen yükümlülügü uyarınca, tıbbi müdahale sonucunda bir komplikasyon oluşması halinde zamanında tanı ve tedavi uygulamalıdır. Aksi takdirde özen yükümlülügünün ihlali sebebiyle kusurlu addedilir.

\section{b. Geleneksel ve Tamamlayıc Tip Uygulamalarında Komplikasyon Yönetimi}

Geleneksel ve tamamlayıcı tıp uygulamasını özen yükümlülüğünü gereği gibi yerine getirerek seçen doktor, hem tedavinin uygulama sürecinde, hem de tedavi sonrası oluşabilecek komplikasyonların takibi aşamasında özen yükümlülügünü yerine getirmek zorundadır. Bu bağlamda özen yükümlülüğü uyarınca doktor, uygulama sırasında ve sonrasında, ilgili yöntemin tıbbi standarttan sapıp sapmadığını değerlendirmek, saptığının tespiti halinde tedavinin seyrini sürekli izlemek, tekrar tekrar değerlendirmek ve teste tabi tutmak zorundadır. Doktor, tedavi süreci boyunca yaptığı değerlendirmeler sonucunda, yalnızca olumlu bir sonuç ile karşılaşırsa, ilgili geleneksel ve tamamlayıcı tıp uygulamasına devam etmelidir. Bunun sebebi ise, şimdiye kadar bilinmeyen risklerin ve yan etkilerin özellikle beklenmesinden kaynaklanmaktadır. Doktor, tedavi sırasında yöntemin istenen etkisinin gerçekleşmediği ve hastanın sağlığında herhangi bir iyileşme gözlenmediği takdirde, yine ilgili tedavi yöntemine devam etmeyi bırakmalıdır. Aksi takdirde, hasta beyhude bir tedaviye maruz kalabilir. Aynı şekilde uygulama sırasında, hasta için nedeni, niteliği ve kapsamı henüz tam olarak bilinmeyen ancak sağlığa ciddi zararlar verebilecek riskler ortaya çıkar ise doktor, standart tıbbi bir yönteme geçmeyi ciddi olarak düşünmeli veya gerekirse tedaviye ara vermelidir ${ }^{143}$. Zira doktorun tedavi sirasında veya sonrasında ortaya çıkan riskler ve yan etkilere ilişkin derhal müdahale etme yükümlülüğü bulunmaktadır ${ }^{144}$.

143 Bu durum, özellikle geleneksel ve tamamlayıcı tıbbi tedavi sırasında sağlık durumunun iyileşmediği veya daha da kötüleştiği açıkça ortada olan ciddi hastalık vakaları için geçerlidir, Müller/Raschke, s. 431; Eğer doktor tarafından uygulanmak istenen geleneksel ve tamamlayıcı tıbbi uygulamanın şimdiye kadar kanıtlanmış herhangi iyileştirici bir etkisi yoksa, hasta açıkça konvansiyonel tıbbi uygulamayı reddetmemişse ve bu uygulama doktor tarafindan bir ücret mukabilinde gerçekleştiriliyorsa, bu durumda doktorun malpraktis (Behandlungsfehler) sorumluluğunun doğduğunun kabulü gereklidir, Schmid, s. $2341 \mathrm{vd}$.

144 Gerhard, Wagner: Neuartige Behandlungmethoden und Arzneimittel, Placebos, Münchener Kommentar zum Bürgerlichen Gesetzbuch (Hrsg.: Säcker, Franz Jürgen/ Rixecker, Roland/Oetker, Hartmut/Limperg, Bettina), 8. Auflage, Verlag C. H. Beck, 
Günümüzde geleneksel veya tamamlayıcı tıp uygulaması sadece doktorlara mahsus değildir. İlgili geleneksel ve tamamlayıcı tıp uygulaması, tıp eğitimi almamış sağlık meslek mensubu tarafindan gerçekleştirilmekteyse, sertifikalı sağlık meslek mensubunun da, aynı tedavi yöntemine ilişkin sertifikaya sahip bir doktorla aynı bilgi düzeyine sahip olması kendisinden beklenemese de, en azından kendisi için gerekli olan eğitim temelinde ilgili tedavi yönteminin güvenli uygulanabilmesi için gerekli olan doğru tekniklere ve ilgili yöntemin fayda ve risklerine ilişkin yeterli bilgi sahibi olması gerekmektedir. Ayrıca sağlık meslek mensubunun da, tıpkı doktor gibi, tedavi süresince ve sonrasında özen yükümlülüğü bulunmaktadır. Ancak bir doktorun kendisine yüklenen özen yükümlülüğü, sağlık meslek mensubuna göre daha yüksektir. Bunun sebebi ise, hastanın doktora daha fazla güven duymasından ileri gelmektedir. Zira bir hasta, ilgili geleneksel ve tamamlayıcı tıp uygulamasına ilişkin sertifikaya sahip bir doktor tercih ettiğinde, tıbbi standardın varlığına güvenir ${ }^{145}$. Fakat bu durumun istisnası bulunmaktadır. Buna göre, tıp eğitimi almamış sağlık meslek mensubu, ilgili geleneksel ve tamamlayıcı tıp uygulaması kapsamında deri bütünlüğünü bozan (invaziv) bir tedavi uyguluyor ise, bu durumda sağlı meslek mensubunun özen yükümlülüğünün de, doktorun özen yükümlülüğü ile aynı düzeyde olduğu kabul edilmelidir ${ }^{146}$.

München 2020, Rn. 134; Schumacher, Arzthaftungsrecht, s. 790; Müller/Raschke, s. 430 vd.; Vogeler, s. 702; Karş. BGH, NJW, 2007, s. 2767 vd.; BGH, NJW, 2007, s. 2774 vd.; BGH, NJW, 2011, s. 1090, <https://beck-online.beck.de > E.T.: 21.01.2021; Akyıldız, s. 211 vd.; Konuya ilişkin Yargitay kararına göre, "Doktor, hastanın zarar görmemesi için, mesleki tüm şartları yerine getirmek, hastanın durumunu tıbbi açıdan zamanında ve gecikmeksizin saptayıp, somut durumunun gerektirdiği önlemleri eksiksiz bir şekilde almak, uygun tedaviyi de yine gecikmeden belirleyip uygulamak zorundadır. Asgari düzeyde dahi olsa bir tereddüt doğuran durumlarda, bu tereddüdü ortadan kaldıracak araştırmalarl yapmak ve bu arada da koruyucu tedbirleri almakla yükümlüdür... Bu durumda, davalıların hukuki konum ve sorumluluklarl, dosyada mevcut delillerle birlikte bir bütün olarak değerlendirilip, yapılması gerekenle yapllan müdahale ve işlemlerin ne olduğu, tıbbın gerek ve kurallarına göre olayda davalılara kusur izafe edilip edilmeyeceği, hastaya hekimin derhal müdahale etmesinin gerekip gerekmediği, hayati risk taşıyı taşımadı̆̆l, hastanın sağlığı açısından uygulanacak tedaviyi ret etme

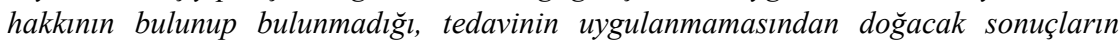
hastaya veya veyahut yakınlarına anlatılip anlatılmadĭ̆ ve yazllı bir belgenin neden alınmadĭ̆ına ilişkin inceleme ve değerlendirme yapılmalıdır.", Y13HD., 17.12.2019 T., 2018/5555 E., 2019/12706 K., <https://www.kazancihukuk.com> E.T.: 05.04.2021.

145 Müller/Raschke, s. 432; Aynı yönde Alman Federal Yüksek Mahkeme kararı için bkz. BGH, NJW, 1991, s. 1535 vd., <https://beck-online.beck.de > E.T.: 04.02.2021.

146 BGH, NJW, 1991, s. 1537 vd., <https://beck-online.beck.de > E.T.: 04.02.2021; Konuya ilişkin olarak doktrinde yer alan bir görüşe göre, hasta konvansiyonel tıp yerine henüz 


\section{SONUÇ}

Dünya geneline bakıldığında, geleneksel ve tamamlayıcı tedavi yöntemlerinin yelpazesi oldukça geniştir. Ancak Sağlık Bakanlı̆̆ 1 , Geleneksel ve Tamamlayıcı Tıp Uygulamaları Yönetmeliği kapsamında sadece on beş tedavi yöntemini düzenlemiştir. Sağlık Bakanlığı'nın bu elemeyi neye göre yaptığı tam olarak kestirilememektedir. Zira ilgili yönetmelikte bahsi geçen bazı tıp uygulamaları (örneğin, akupunktur, mezoterapi, proloterapi, ozon terapi, sülük, kupa, larva uygulaması gibi), vücut bütünlüğünü bozabilecek fiiller içermekteyken; bazıları (örneğin, müzik terapi gibi) içermemektedir. Ayrıca ilgili yönetmelik, hukuki yönden ele alındığında oldukça eksiktir. Nitekim ilgili yönetmelikte, ne yapılan uygulamaların hukuka aykırılı̆̆ına ilişkin, ne de uygulayıcıların hukuki sorumluluğuna ilişkin özel hükümler yer almaktadır. Geleneksel ve tamamlayıcı tıp uygulamaları, bir çok yönden konvansiyonel tıp uygulamalarından farklıdır. Bu farklar arasında, geleneksel ve tamamlayıcı tedavi yöntemlerinin pozitif bilimlere dayanmaması, çoğu zaman bilimsel deneylerin süzgecinden geçirilmemesi, etkinliğinin ve risklerinin belirsizliği, bilimsel verilerle kanıtlanmamış olması ve bilimsel yönden fikir birliği eksikliği ile karakterize olması sayılabilir. Dolayısıyla kanun koyucu tarafından, ilgili uygulamalara ilişkin olarak yasal düzenlemelerin sayısı veya yasal düzenlemenin hukuki kapsamının arttırılması, toplum sağlığı ve güvenliği açısından gereklidir.

etkinliği kesin olarak kanıtlanmamış herhangi bir geleneksel ve tamamlayıcı tedavi yöntemini ve bu yöntemi gerçekleştirmeye yetkili sertifikalı bir doktoru tercih etmişse, ancak gerekli doktor tarafından özen yükümlülüğünün yerine getirilmemesi sonucunda "öngörülebilen" bir komplikasyon meydana gelmiş ise, hastanın (BGB § 254/S. 1-TBK. m. 52) ortak kusurunun varlığından söz edilmelidir. Zira alternatif tedaviyi arzulayan hastanın bunu tercih etmesi, onun da bu riskin oluşmasında payı olduğunu göstermektedir. Aynı şekilde geleneksel ve tamamlayıcı tedavi yöntemini tercih etmiş, ancak kendi sağlığını bilinçli (kasıtlı) olarak "doktor olmayanlara" emanet etmiş hastaların özen yükümlülüğünün yerine getirilmemesi sonucunda meydana gelen "öngörülemeyen" komplikasyonların sonuçlarına dahi birlikte katlanmaları gerekmektedir. Bir başka ifadeyle, hastalığının tedavisinde konvansiyonel tıp yerine, geleneksel ve tamamlayıcı yöntemi ve buna ilişkin sertifikaya sahip bir doktoru seçen hasta, öngörülebilen bir komplikasyon meydana geldiğinde meydana gelen riskin sonuçlarından ortak kusuru sebebiyle, doktorla birlikte sorumludur. Ancak özen yükümlülügünün ihlali sebebiyle öngörülemeyen komplikasyonların meydana gelmesi halinde, doktorun meydana gelen riske tek başına katlanması gerekmektedir. Eğer aynı hasta, sertifikalı bir doktor yerine bir de sağlık meslek mensubunu seçmişse, bu durumda öngörülemeyen riskler de dahil, ortak kusur sebebiyle sağlık meslek mensubu ile birlikte riskin sonuçlarına katlanmalıdır. Konuya ilişkin ayrıntılı bilgi için bkz. Taupitz, Jochen: "Der Heilpraktiker aus der Sicht des Haftungsrechts: “Arzt", "Mini-Arzt" oder "Laie"?", NJW, Heft 24, Y. 1991, s. $1505 \mathrm{vd}$. 
Sağlık Bakanlığı tarafindan Geleneksel ve Tamamlayıcı Tıp Uygulamaları Yönetmeliği'nde kabul edilen uygulamalar, tıbbi müdahale kapsamında kabul edilmelidir. Dolayısıyla tıbbi müdahalenin hukuka uygunluğu için gereken şartlar, geleneksel ve tamamlayıcı tıp uygulamaları için de geçerli olmalıdır. Ancak ilgili tıp uygulamalarının hukuka uygunluğunun tespitinde, standart tedavi ilkeleri doğrultusunda genelleme yapmak yerine, anılan genel ilkelerin içeriğinde bir takım özel kriterlerin aranması makul görülmektedir. Bu bağlamda geleneksel ve tamamlayıcı tıp uygulamalarının hukuka uygun sayılabilmesi için, mutlaka her bir uygulama için ilgili yönetmelikte öngörülen yetkili kişi tarafından gerçekleştirilmeleri gerekmektedir. Yetkili kişiler, geleneksel ve tamamlayıcı tıp uygulamalarını hastalığın teşhisinde kullanmamalı; aksine konvansiyonel tıp teşhiste belirleyici olmalıdır. Bununla birlikte, hastalık teşhis edildikten sonra, hastaya kullanılacak tedavi yöntemi hususunda, yetkili kişilerin hareket alanı genişlemelidir. Keza doktor, tedavi yöntemini seçme konusunda özgürdür. Dolayısıyla, doktorun tedavi yöntemi olarak konvansiyonel tıptan ayrılması ve geleneksel-tamamlayıcı tıp uygulamasına yönelmesi, hukuka aykırılı̆̆ın doğması için yeterli bir sebep olmamalıdır. Ancak doktorun bu özgürlüğü, sınırsız da değildir. Doktorun bu özgürlüğü, hastanın kendi kaderini tayin hakkının başladığı yerde bitmektedir. Eğer doktor, hastalığın tedavisinde standart tedavi yöntemi yerine, geleneksel ve tamamlayıcı tedavi yöntemini uygulamak istiyorsa, bunu mutlaka haklı gerekçelere dayandırmak zorundadır. Aksi takdirde doktor, özen yükümlülüğünü ihlal etmiş sayılmalıdır. Ayrıca tedavi yöntemi seçimi noktasında, doktorun mesleki özgürlüğü, hastanın kendi kaderini tayin hakkı ve sağlığının korunması arasında denge sağlanmalıdır. $\mathrm{Bu}$ dengenin sağlanması ise, tıbbi müdahale öncesi doktorun aydınlatma yükümlülüğünü yerine getirmesine, hastanın özgür iradesiyle ilgili müdahaleye rıza göstermesine ve doktorun özen yükümlülüğüne bağlıdır. Dolay1sıyla, geleneksel ve tamamlayıcı tıp uygulamalarında, doktorun aydınlatma ve özen yükümlülügü çok önemlidir; konvansiyonel tıp uygulamalarına nazaran kapsamı ve yoğunluğu mutlaka arttırılmalıdır.

Doktorun tedavi seçimindeki özgürlüğü ve hareket alanının genişliğinin aksine, tedavinin uygulanması sırasında tıbbi standardın sağlanması noktasında, doktora aynı hareket alanı tanınmamalıdır. Geleneksel ve tamamlayıcı tedavi yöntemlerinin uygulanması, bunların pozitif bilimlere dayanmaması, çoğu zaman bilimsel deneylerin süzgecinden geçirilmemesi, etkinliğinin ve risklerinin belirsizliği ve bilimsel yönden fikir birliği eksikliği ile karakterize olması sebebiyle, tıbbi standarttan sapma anlamına gelmektedir. Ancak tıbbi standarttan her türlü sapma, hukuka aykırılık olarak nitelendirilmemelidir. 
Burada, her küçük sapmanın bir iyileştirme girişimi olarak görülmesi gerekip gerekmediği veya sapmanın önemli olup olmadığı, hastanın iyileşmesi amacıyla tıbbi standartlardan kasıtlı olarak sapmanın var olup olmadığ ve doktorun hastanın rizası olmadan tıbbi standarttan sapıp sapmadığının değerlendirilmesi belirleyici olmalıdır. Ayrıca doktor, geleneksel ve tamamlayıcı tıp uygulaması sırasında ve sonrasında özen yükümlülüğü gereğince, ilgili yöntemin tıbbi standarttan sapıp sapmadığını değerlendirmeli, saptığının tespiti halinde tedavinin seyrini yakından takip etmeli ve tekrar tekrar değerlendirerek teste tabi tutmalıdır. Doktor, tedavi süreci boyunca yaptığı değerlendirmeler sonucunda, yalnızca olumlu bir sonuç ile karşılaşırsa, ilgili geleneksel ve tamamlayıcı tıp uygulamasına devam etmelidir. Aksi takdirde doktor, derhal müdahale etme yükümlülüğü çerçevesinde, standart tıbbi bir yönteme geçmeyi ciddi olarak düşünmeli veya gerekirse tedaviye ara vermelidir. Geleneksel ve tamamlayıcı tıp uygulamalarına açık olan konvansiyonel tıp doktoru, gerek hastanın bulgularını değerlendirirken, gerek uygulama sırasında ve sonrasında konvansiyonel tıbba bağlılığını sürdürmelidir. 


\section{KAYNAKÇA}

Akyıldız, Sunay: "Tıbbın Uygulanmasından Doğan Tazminat Davaları ve Temel Unsurları", Legal Tip Hukuku Dergisi, C. 1, S. 1, Y. Nisan 2012, s. 205-217.

Antalya, Gökhan: 6098 Sayılı Türk Borçlar Kanununa Göre Borçlar Hukuku Genel Hükümler, C. 1, Beta Yayınları, Ankara 2012.

Atalık, Ahmet: "Mezoterapi ve Klinik Uygulamalar", Journal of Biotechnology and Strategic Health Research, C. 3, S. Özel Sayı, Y. 2019, s. 115-118.

Ayan, Mehmet: Tibbi Müdahalelerden Doğan Hukuki Sorumluluk, Kazanc1 Yayınları, Ankara 1991.

Aydın, Sabahattin: "DSÖ ve Gelenekten Küresele Tıbbın Alternatif Serüveni”, Sağlık Düşüncesi ve Tıp Kültürü Dergisi, S. 22, Y. MartNisan-May1s 2011-2012, s. 8-11.

Aydın, Yıldıray/Tekeoğlu, İbrahim: "Tamamlayıcı Tıp ve Güncel Apiterapi Uygulamaları", Journal of Biotechnology and Strategic Health Research, C. 2, S. 2, Y. 2018, s. 64-73.

Ayhan, Hüseyin/Mollahaliloğlu, Salih: "Trbbi Sülük Tedavisi: Hirudoterapi”, Ankara Medical Journal, C. 18, S. 1, Y. 2018, s. 141148.

Aytaçoğlu, Saltuk: "Ozon Terapi”, Ankara Akupunktur ve Tamamlayıcı Tıp Dergisi, S. 1, Y. 2014, s. 31-36.

Biçer, İsmail/Balçık, Pınar Yalçın: "Geleneksel ve Tamamlayıcı Tıp: Türkiye ve Seçilen Ülkelerinin İncelenmesi”, Hacettepe Sağlık İdaresi Dergisi, C. 22, S. 1, Y. 2019, s. 245-257.

Bodenburg, Reinhard: "Alternative Medizin im Spannungsfeld von Heilungschancen und ärztlichem Risiko", NJOZ, Heft 33, Y. 2009, s. 2823-2830.

Böttger, Ralf/Kirchner, Christiane: Arzneimittelrecht, Handbuch für die Rechtspraxis (Hrsg.: Fuhrmann, Stefan/Klein, Bodo/Fleischfresser, Andreas), 3. Auflage, Nomos, Baden-Baden 2020.

Buda, Levent: Bir Tedavi Sanati: Homeopati, Homeopatik Ev Eczanesi, 2. Baskı, A7 Kitap Yayıncılık, İstanbul 2018.

Ceyhan, Derya/Yiğit, Tuğba Tasa: "Tıbbi Tedavilerde Hipnoz Uygulamalarının Kullanımı ve Etkinliği”, Ankara Diş Hekimleri Odası Klinik Bilimler Dergisi, C. 7, S. 2, Y. 2013, s. 1507-1516. 
Civaner, M. Murat: "Hekimin Modern Tıp Dışı Yöntemlere Yaklaşımı Nasıl Olmalı?”, Toplum ve Hekim, C. 32, S. 1, Y. Ocak-Şubat 2017, s. 9-13.

Çelikbaş, Aysel Kocagül: "GATT Uygulamalarına Enfeksiyon Hastalıkları Açısından Yaklaşım”, Tibbın Alternatifi Olmaz!, Geleneksel, Alternatif ve Tamamlayıcı Tıp Uygulamaları, Türk Tabipleri Birliği Yayınları, Ankara 2017, s. 219-231.

Damm, Reinhard: "Medizintechnik und Arzthaftungsrecht: Behandlungsfehler und Aufklärungspflicht bei medizintechtechnischen Behandlungsalternativen", NJW, Heft 12, Y. 1989, s. 737-744.

Deutsch, Erwin/Spickhoff, Andreas: Medizinrecht: Arztrecht, Arzneimittelrecht und Medizinprodukterecht und Transfusionsrecht, 6. neu bearbeitete und erweiterte Auflage, Springer Verlag, Berlin 2008.

Dişli, Meryem/Yeşilada, Erdem: "Türkiye'de Bitkisel T1bbi Ürünler (Türkiye'de Bitkisel Ürünlerin Standardizasyonu, Üretimi ve Tağşiş)", Journal of Biotechnology and Strategic Health Research, C. 3, S. Özel Say1, Y. 2019, s. 13-21.

Eichelberger, Jan: Medizinrecht, Becksche Kurz Kommentare Band 64 (Hrsg.: Andreas Spickhoff), 3. Auflage, Verlag C. H. Beck, München 2018.

Engisch, Karl: "Heilengriff und ärztliche Aufklärungspflicht", Die ärztliche Aufklärungspflicht aus rechtlicher und ärztlicher Sicht (Hrsg.: Engisch, Karl/Hallermann, Wilhelm), Carl Heymann Verlag, Köln 1970, s. 7-43.

Eren, Fikret: 6098 Sayılı Türk Borçlar Kanununa Göre Hazırlanmış Borçlar Hukuku Genel Hükümler, 15. Bask1, Yetkin Yayınları, Ankara 2013.

Fink, Claudia: Die Aufklärungspflicht von Medizinalpersonen (Arzt, Zahnarzt, Tierarzt, Apotheker), Stämpfli Verlag, Bern 2008.

Geiß, Karlmann/Greiner, Hans Peter: Arzthaftpflichtrecht, 7. überarbeitete Auflage, Verlag C. H. Beck, München 2014.

Gerhard, Wagner: Neuartige Behandlungmethoden und Arzneimittel, Placebos, Münchener Kommentar zum Bürgerlichen Gesetzbuch (Hrsg.: Säcker, Franz Jürgen/Rixecker, Roland/Oetker, Hartmut/Limperg, Bettina), 8. Auflage, Verlag C. H. Beck, München 2020.

Hakeri, Hakan: "Geleneksel Tıp Bakımından Ülkemizdeki Hukuki Durum", Legal Tip Hukuku Dergisi, C. 4, S. 7, Y. Nisan 2015, s. 17-41. (Hakeri, Geleneksel Tip) 
Hakeri, Hakan: "Tibbi Müdahalenin Hukuka Uygunluğunun Şartları”, Legal Tip Hukuku Dergisi, C. 3, S. 6, Y. Ekim 2014, s. 17-44. (Hakeri, T1bbi Müdahale)

Hakeri, Hakan: Tıp Hukuku, 19. Baskı, Seçkin Yayıncılık, Ankara 2020. (Hakeri, Tip)

Hakeri, Hakan: "Tip Hukukunda Malpraktis ve Komplikasyon Ayrımı", Toraks Cerrahi Bülteni, C. 5, S. 1, Y. Mart 2014, s. 23-28. (Hakeri, Komplikasyon)

Hauck, Ernst: "Rechtsgrundlagen der medizinischen Indikationsstellung", NJW, Heft 46, Y. 2013, s. 3334-3340.

Helbron, Hanja: Entwicklungen und Fehlentwicklungen im Arzthaftungsrecht, Herbert Utz Verlag, München 2001.

Helmstädter, Axel: "Hahnemann und die Homöopathie: Alternativ seit 250 Jahren", PharmR, Heft 1, S. 13, Y. 2006, s. 13-18.

İkizek, Mustafa/Uzuntarla, Yasin: "Medikal Ozon Tedavisi ve Covid-19", Sağl1k Akademisyenleri Dergisi, C. 7, S. 4, Y. 2020, s. 304-310.

Jansen, Christoph: "Behandlungs- und Aufklärungsfehlerhaftung bei der Wahl eines nicht standartgemäßen Behandlungskonzept", MedR, S. 38, Y. 2020, s. 379-382.

Kalyon, Tunç Alp: "Akupunktur Tedavisi”, Türk Fizyoterapi ve Rehabilitasyon Dergisi, C. 53, S. Özel Say1 2, Y. 2007, s. 52-57.

Katzenmeier, Christian: BeckOK BGB (Hrsg.: Hau, Wolfgang/Poseck, Roman), 56. Auflage, Verlag C. H. Beck, München 2020. (Katzenmeier, BeckOK)

Katzenmeier, Christian: "Rechtsfragen der Placebobehandlung", MedR, S. 36, Y. 2018, s. 367-373. (Katzenmeier, Placebo)

Karahancı, Onur Naci/Öztoprak, Ümit Yaşar/Ersoy, Mesut/Ünsal, Çağrı Zeybek/Hayırlıdăg, Mustafa/Büken, Nüket Örnek: “Geleneksel ve Tamamlayıcı Tıp Uygulamaları Yönetmeliği ile Yönetmelik Taslağı'nın Karşılaştırılması", Türkiye Biyoetik Dergisi, C. 2, S. 2, Y. 2015, s. 117-126.

Kassel, Martin Estelmann: "Placeboeffekte-interdisziplinär betrachtet", NZS, Heft 13, Y. 2018, s. 526-529.

Kavaklı, Ahmet: "Akupunktur”, Firat T1p Dergisi, C. 15, S. 1, Y. 2010, s. 14. 
Kaya, Elif/Altınbilek, Turgay: "Osteopati Yaklaşımı; Bel ve Boyun Ağrılarında Yeri", Journal of Biotechnology and Strategic Health Research, C. 3, S. Özel Say1, Y. 2019, s. 85-90.

Kern, Bernd Rüdiger/Laufs, Adolf: Die ärztliche Aufklärungspflicht, Springer Verlag, Berlin 1983.

Khan, Abdul Sattar/Aktürk, Zekeriya: "Tamamlayıcı ve Alternatif Tedaviler Ne Kadar Kanıta Dayalı?”, Sağlık Düşüncesi ve Tıp Kültürü Dergisi, S. 22, Y. Mart-Nisan-May1s 2012, s. 16-19.

Kıvan, Çevik: "Hemşirelikte Tamamlayıcı ve Alternatif Tedavi: Refleksoloji”, Ege Üniversitesi Hemşirelik Fakültesi Dergisi, C. 29, S. 2, Y. 2013, s. 71-82.

Kieser, Ueli/Nedi, Marian: "Komplementärmedizin: Was legt Art. 118a BV fest?", Hill: Zeitschrift für Recht und Gesundheit, S. 72, Y. 2013, Rn. $1-51$.

Kim, Min-Joong: Aufklärungspflicht im Arztrecht - Eine zivilrechtliche Untersuchung über den Umfang und die Grenzen der ärztlichen Aufklärungspflicht mit rechtsvergleichenden Hinweisen, Göttingen 1989.

Kreße, Bernhard: "Ärztliche Behandlungsfehler durch wirtschaftlich motiviertes Unterlassen", MedR, S. 25, Y. 2007, s. 393-400.

Laufs, Adolf/Katzenmeier, Christian/Lipp, Volker: Arztrecht, 8. völlig neu bearbeitete Auflage, C.H. Beck, München 2021.

Mollahaliloğlu, Salih/Uğurlu, F. Gülçin/Kalaycı, Mehmet Zafer/Öztaş, Dilek: "Geleneksel ve Tamamlayıc1 Tip Uygulamalarında Yeni Dönem”, Ankara Medical Journal, C. 15, S. 2, Y. 2015, s. 102-105.

Müller, Sebastian/Raschke, Andreas: "Homöopathie durch Ärzte und die Einhaltung des medizinischen Standards", NJW, Heft 7, Y. 2013, s. 428-432.

Oğuz, Yasemin: "Toplum, Bilim ve Tip Etiği Açısından Alternatif Tip ve Halk Tıbbı”, Bilim ve Ütopya, S. 25, Y. Temmuz 1996, s. 36-37.

Okumuş, Müyesser: "Kupa Tedavisi ve Hacamat”, Ankara Medical Journal, C. 16 , S. 4, Y. 2016, s. 370-382.

Özer, Oktay: "Tıbbi Müdahalenin Hukuka Uygunluğunun Şartları”, İstanbul Barosu Dergisi, C. 90, S. 5, Y. Eylül-Ekim 2016, s. 117-134.

Özgül, Mehmet Emin: Yeni Tıbbi Yöntemlerin Hukuka Uygunluğu, On İki Levha Yayıncıl1k, İstanbul 2010. 
Öztürk, Levent/Özbek, Hanefi: "Küllerinden Doğan Bir Tıbbi Uygulama: Müzik Terapi”, Sağlık Hizmetleri ve Eğitimi Dergisi, C. 2, S. 1, Y. 2018, s. 1-8.

Öztürk, Yunus Emre/Dömbekci, Hilal Akman/Ünal, Seda Nur: "Geleneksel, Tamamlayıcı ve Alternatif Tıp Kullanımı", Bütünleyici ve Anadolu T1bbi Dergisi, C. 1, S. 3, Y. 2020, s. 23-35.

Roggo, Antoine: Aufklärung des Patienten-eine ärztliche Informationspflicht, 1. Auflage, Stämpfli Verlag, Bern 2002.

Sandoz, Thomas: Alternatif Tıp Tarihi, Çev. Çağn Eroğlu, Dost Kitabevi, Ankara 2010.

Sarıyev, Ayşe Erol: Alternatif Tibbi Yöntemlerden Kaynaklanan Hukuki Sorumluluk, Adalet Yayınevi, Ankara 2015.

Schelling, Philip/Erlinger, Rainer: "Die Aufklärung über Behandlungsalternativen", MedR, Heft 6, Y. 2003, s. 331-334.

Schmid, Hugo: "Die Grenzen der Therapiefreiheit", NJW, Heft 38, Y. 1986, s. 2339-2343.

Schubarth, Martin: "Therapiefreiheit des Arztes und Selbstbestimmungsrecht des Patienten Konsequenzen für das Arztstrafrecht und die formula magistralis", AJP, S. 9, Y. 2007, s. 1089-1095.

Schumacher, Katrin: Alternativmedizin: Arzthaftungsrechtliche, arzneimittelrechtliche und sozialrechtliche Grenzen iffrztlicher Therapiefreiheit, Kölner Schriften zum Medizinrecht, Springer, Berlin 2017. (Schumacher, Alternativmedizin)

Schumacher, Katrin: "Arzthaftungsrecht aus alternativmedizinischer Sicht", MedR, S. 37, Y. 2019, s. 786-791. (Schumacher, Arzthaftungsrecht)

Shenbao, Liang: Einwilligung in medizinische Behandlungen, eine rechtsvergleichende Analyse nach schweizerischem und chinesischem Privatrecht, Arbeiten aus dem Juristischen Seminar der Universität Freiburg Schweiz (Hrsg.: Peter Gauch), Schulthess, Zürich 2018.

Somer, Pervin: "Ülkemizde Tamamlayıcı ve Alternatif Tibbın Hukuki Dayanağı ve Sorumluluk Alanları Üzerine”, Sağlık Düşüncesi ve Tıp Kültürü Dergisi, S. 22, Y. Mart-Nisan-Mayıs 2011-2012, s. 48-49.

Somer, Pervin/Lutz, Emine Elif Vatanoğlu: "Geleneksel ve Tamamlayıcı Tip Uygulamaları Yönetmeliği'nin Hukuki ve Etik Açıdan Değerlendirilmesi”, Anadolu Kliniği Tıp Bilimleri Dergisi, C. 22, S. 1, Y. Ocak 2017, s. 58-65. 
Söbbing, Thomas: "Rechtsfragen homöopathischer Arzneimittel", InTer, S. 3, Y. September 2019, s. 127-131.

Söğüt, İpek Sevda: "Geleneksel ve Tamamlayıcı Tıp Uygulamalarında Aydınlatılmış Onam Sorunu", İstanbul Kültür Üniversitesi Hukuk Fakültesi Dergisi, C. 2, S. 16, Y. 2017, s. 627-649.

Spickhoff, Andreas: "Erforderliche Sorgfalt und Umfang der Aufklärungspflicht bei Anwendung einer Außenseitermethode", MedR, S. 26, Y. 2008, s. 87-90.

Şahin, Çağrı Emin: "Tıbbın Alternatifi mi? Tıpta Alternatif mi?", Hayat Sağlık: Sağlık ve Sosyal Bilimler Dergisi, S. 17, Y. Temmuz 2018, s. 17-21. (Şahin, Tıpta Alternatif)

Şahin, Saliha: "Geleneksel, Tamamlayıcı, Alternatif Tıp Uygulamalarına Genel Bir Bakış", Türkiye Aile Hekimliği Dergisi, C. 21, S. 4, Y. 2017, s. 159-162. (Şahin, Genel Bir Bakış)

Şatır, Nejdet: Emsal Kararlar Işı̆̆ında Kamu ve Özel Hastanelerde Çalışan Hekimlerin Hukuki ve Cezai Sorumluluğu, 2. Bask1, Yekin Yayınevi, Ankara 2018.

Tamam, Cüneyt/Tamam, Yusuf: "Farklı Bir Bozucu Alan Nedeni: Hacamat", Bilimsel Tamamlayıcı Tıp Regülasyon ve Nöral Terapi Dergisi, C. 12, S. 1, Y. 2018, s. 26-27.

Taneri, Petek Eylül/Akış, Nalan: "Geleneksel, Alternatif ve Tamamlayıcı Tıp Yöntemleri”, Tıbbın Alternatifi Olmaz!, Geleneksel, Alternatif ve Tamamlayıc1 Tıp Uygulamaları, Türk Tabipleri Birliği Yayınları, Ankara 2017, s. 55-97.

Tanyüksel, Mehmet/ Koru, Özgür/Araz, Remzi Engin/Kılbaş, Hatice Zeynep Güçlü/Yıldız, Şenol/Alaca, Rıdvan/Ay, Hakan/Şimşek, Kemal/Yıldız, Cemil/Yurttaş, Yüksel/Demiralp, Bahtiyar/Deveci, Mustafa/Beşirbellioğlu, Bülent A.: "Kronik Yaraların Tedavisinde Steril Lucilia Sericata Larva Uygulamaları", Gülhane Tıp Dergisi, C. 56, S. 4, Y. 2014, s. 218-222.

Taşçı, Ali İhsan: "Adli Tıp Penceresinden Alternatif Tıp Uygulamaları", Sağlık Düşüncesi ve Tıp Kültürü Dergisi, S. 22, Y. Mart-Nisan-Mayıs 2012, s. 50-51.

Taştan, Kenan: "Ülkemizde Geleneksel ve Tamamlayıcı Tıbbın Kilometre Taşları”, Ankara Medical Journal, C. 18, S. 3, Y. 2018, s. 458-459. 
Taupitz, Jochen: "Der Heilpraktiker aus der Sicht des Haftungsrechts: "Arzt", "Mini-Arzt" oder "Laie"?", NJW, Heft 24, Y. 1991, s. 15051510.

Tokaç, Mahmut: "Geleneksel Tibba Akademik Yaklaşım: GETTAM", Sağlık Düşüncesi ve Tıp Kültürü Dergisi, S. 28, Y. Eylül-Ekim-Kasım 2013, s. 82-85. (Tokaç, GETTAM)

Tokaç, Mahmut: "Geleneksel Tıbba Etik ve Hukuk Yönü ile Bakış”, Journal of Biotechnology and Strategic Health Research, C. 3, S. Özel Say1, Y. 2019, s. 155-160. (Tokaç, Etik ve Hukuk)

Tokaç, Mahmut: "Geleneksel ve Tamamlayıcı Tip Uygulamaları Mevzuatı Hakkında", Hayat Sağlık: Sağlık ve Sosyal Bilimler Dergisi, S. 17, Y. Temmuz 2018, s. 22-25. (Tokaç, Tıp Uygulamaları Mevzuatı)

Toptan, Hande/Kaya, Tuğba/Altındiş, Selma: "Geleneksel ve Tamamlayıcı Tip (GETAT) Uygulamalarında Enfeksiyon Kontrol Önlemleri, Hijyen ve Çalışan/Hasta Güvenliğii”, Journal of Biotechnology and Strategic Health Research, C. 3, S. Özel Sayı, Y. 2019, s. 168-172.

Tütüncü, Serpil: "Geleneksel, Alternatif ve Tamamlayıcı T1p Uygulamalarına Genel Bir Bakış", Tıbbın Alternatifi Olmaz! Geleneksel, Alternatif ve Tamamlayıcı Tip Uygulamaları, Türk Tabipleri Birliği Yayınları, Ankara 2017, s. 11-55.

Vardar, Deniz Özkan/Mollahaliloğlu, Salih/Öztaş, Dilek: "Fitoterapide Kullanılan Bazı Fitokimyasalların Toplum Sağlığına Etkilerinin Değerlendirilmesi”, Journal of Health Sciences and Medicine, C. 1, S. 4, Y. 2018, s. 95-105.

Vogeler, Marcus: "Die Haftung des Arztes bei der Anwendung neuartiger und umstrittener Heilmethoden nach der neuen Rechtsprechung des BGH”, MedR, S. 26, Y. 2008, s. 697-707.

Wiegand, Wolfgang: "Die Aufklärungspflicht und die Folgen ihrer Verletzung", Handbuch des Arztrechts (Hrsg.: Heinrich, Honsell), Zürich 1994, s. 119-213.

Yaman, Hakan/Vural, Ramazan: "Proloterapi: Aile Hekimliği'nde Kronik Ağr1 Yönetiminde Yeni Bir Yöntem”, Ankara Medical Journal, C. 16, S. 2, Y. 2016, s. 220-224.

Yarış, Ersin: "Molekülden İlaca Ama Bitkiden Nereye", Tıbbın Alternatifi Olmaz!, Geleneksel, Alternatif ve Tamamlayıcı Tip Uygulamaları, Türk Tabipleri Birliği Yayınları, Ankara 2017, s. 109-120. 
Yeşilada, Erdem: "Hekim, Alternatif Tedavi ve Modern Tıp", TTB Sürekli Tıp Eğitimi Dergisi, C. 11, S. 6, Y. 2002, s. 223-225.

Zeytin, Zafer: "Hasta-Hekim İlişkisinde Hekimin Aydınlatma Yükümlülüğü”, Sağlık Hakkı Dergisi, Türk-Alman Tıp Hukuku Sempozyumu Özel Sayıs1, S. 3, Y. 2007, s. 165-190.

\section{Diğer Kaynaklar}

https://beck-online.beck.de

http://www.dergipark.org.tr

http://www.kazancihukuk.com

http://www.legal.com.tr

https://sozluk.gov.tr

http://www.springer.com

https://swisslex.ch

https://www.ttb.org.tr 
KISALTMALAR

$\begin{array}{ll}\text { AJP } & \text { : Aktuelle Juristische Praxis } \\ \text { BGB } & \text { : Bundesgesetzbuch } \\ \text { BGH } & \text { : Bundesgerichtshof } \\ \text { Bkz. } & \text { : Bakınız } \\ \text { BV } & \text { : Bundes-Verfassung (Schweiz) } \\ \text { C. } & \text { : Cilt } \\ \text { Çev. } & \text { : Çeviren } \\ \text { E. } & \text { : Esas } \\ \text { E.T. } & \text { : Erişim Tarihi } \\ \text { YHD. } & : \text { Yargitay Hukuk Dairesi } \\ \text { YHGK. } & \text { : Yargitay Hukuk Genel Kurulu } \\ \text { Hrsg. } & \text { : Herausgeber } \\ \text { InTer } & \text { : Zeitschrift zum Innovations- und Technikrecht } \\ \text { K. } & \text { : Karar } \\ \text { m. } & : \text { madde } \\ \text { MedR } & \text { : Medizin Recht (Fachzeitschrift) } \\ \text { NJOZ } & \text { : Neue Juristische Online Zeitung } \\ \text { NJW } & \text { : Neue Juristische Wochenschrift } \\ \text { NZS } & \text { : Neue Zeitschrift für Sozialrecht } \\ \text { PharmR } & : \text { Pharma Recht (Fachzeitschrift) } \\ \text { TTB } & \text { : Türk Tabipleri Birliği } \\ \text { VersR } & \text { : Versicherungsrecht (Fachzeitschrift) } \\ \end{array}$


